University of Zurich

Department of Economics

Working Paper Series

ISSN 1664-7041 (print)

ISSN 1664-705X (online)

Working Paper No. 384

\title{
Induced Automation: Evidence from Firm-level Patent Data
}

Antoine Dechezleprêtre, David Hémous, Morten Olsen and Carlo Zanella

April 2021 


\title{
Induced Automation: Evidence from Firm-level Patent Data
}

\author{
Antoine Dechezleprêtre David Hémous Morten Olsen \\ Carlo Zanella*
}

April 2021

\begin{abstract}
Do higher wages lead to more automation innovation? To answer this question, we first use the frequency of certain keywords in patent text to create a new measure of automation innovation in machinery. We show that our measure is correlated with a reduction in routine tasks in a cross-sectoral analysis in the US. We combine macroeconomic data from 41 countries and information on geographical patent history to build firm-specific measures of low- and high-skill wages. In a firm-level panel analysis, we find that an increase in low-skill wages leads to more automation innovation with an elasticity between 2 and 5. Placebo regressions show that the effect is specific to automation innovations. Finally, we focus on a specific labor market shock, the German Hartz reforms, and show that they reduced automation innovations by those non-German firms relatively more exposed to Germany.
\end{abstract}

JEL: O31, O33, J20

KEYWORDS: Automation, Innovation, Patents, Income Inequality

*Antoine Dechezleprêtre, OECD, David Hémous, University of Zurich, Morten Olsen, University of Copenhagen and Carlo Zanella, University of Zurich. David Hémous gratefully acknowledges the financial support of the European Commission under the ERC Starting Grant 805007 AUTOMATION. We thank Daron Acemoglu, Lorenzo Casaburi, Patrick Gaule, Michael McMahon, Pascual Restrepo, Joachim Voth and Fabrizio Ziliboti among others for helpful comments and suggestions. We also thank seminar and conference participants at the University of Zurich, Swiss Macro workshop, the University of Copenhagen, the TRISTAN workshop in Bayreuth, the University of Bath, London Business School, the NBER Macroeconomics Across Time and Space Conference, the NBER Summer Institute, the AlpMacro Conference, LMU, Oxford University, Helsinki Graduate School of Economics, TSE, Ecares, Collège de France, Berkeley, EIEF, EC-OECD and IMT Lucca. We thank Amedeo Andriollo, Selina Schön and Shi Suo for fantastic research assistance. 


\section{Introduction}

Do higher wages lead to more labor-saving innovations? And if so, by how much? At a time of fast progress in automation technologies and of political campaigns pushing for higher minimum wages, answering these questions is of central importance as the endogeneity of automation innovations affects both the cost of such policy intervention and their long-term effects. Our paper is the first to establish a causal effect of an increase in labor costs on automation innovations at the firm level.

Answering these question requires overcoming two challenges: identifying automation innovations and finding a source of exogenous variation in labor costs from the perspective of innovating firms. To overcome the first challenge, we develop a new classification of automation patents. We think of automation innovations as innovations which allow for the replacement of workers with machines in certain tasks. We focus on patents in machinery to which our identification strategy is ideally suited. Our classification follows a two-step procedure where we first classify technology categories (IPC and CPC codes) using patent text and then patents using their technology categories. This new classification presents a certain number of advantages: it is transparent, it covers a wide range of automation technologies and it can be built at a highly disaggregated sectoral level. Furthermore, we reproduce the cross-sectoral analysis of Autor, Levy and Murnane (2003) but adding our measure of automation. We find that in the United States, sectors which use equipment with a high share of automation saw a large decrease in routine tasks.

At the country level, technology and wages are co-determined. To find exogenous variation in labor costs, we exploit the fact that automation innovators are often equipment manufacturers which sell their machines to downstream firms in various countries. We conduct two separate exercises. First, we expand on the methodology of Aghion, Dechezleprêtre, Hémous, Martin and Van Reenen (2016, henceforth ADHMV) and use variation in country-level wages. We rely on the PATSTAT database, which contains close to the universe of patents. For each firm, we compute the geographical distribution of its machinery patents pre-sample, which we use as a measure for the distribution of the firm's international exposure. We then compute firm-specific weighted averages of low- and high-skill labor costs using country-level data. These firm-specific labor costs (referred to as wages for simplicity) proxy for the average labor cost paid by the downstream firms of the innovating firms. As a result, for, say, two German firms, we identify the effect of an increase in, say, US wages, on automation innovations, by comparing how 
much more automation innovations increase for the firm which has the higher market exposure to the US.

We conduct our main analysis over the sample period 1997-2011 and use wage data for 41 countries with automation patents for 3,341 firms. We find a substantial effect of wages on automation innovations: higher low-skill wages lead to more automation innovations with an elasticity between 2 and 5 depending on specification. Higher high-skill wages tend to reduce automation, a finding in line with the capital-skill complementarity hypothesis (Krusell, Ohanian, Rios-Rull and Violante, 2000). Our results are robust to the inclusion of country-year fixed effects for the innovator home country and the exclusion of the home country from the wage variable. Importantly, our results are specific to automation innovations and do not extend to other innovations in machinery.

In a second exercise, we focus on a specific labor market shock, namely the Hartz reforms in Germany in 2002-2004. The Hartz reforms are credited with increasing labor supply and reducing labor costs notably for low-skill workers. We analyze the effect of the Hartz reforms and find that they reduced the relative amount of automation innovation undertaken by foreign firms highly exposed to Germany, both in levels and relative to non-automation innovations in machinery.

The theoretical argument that higher wages should lead to more labor-saving technology adoption or innovation is well-understood (e.g. Zeira, 1998). In Hémous and Olsen (forthcoming) and Acemoglu and Restrepo (2018a), wages affect the direction of innovation which can take the form of automation or the creation of new tasks.

There is an extensive empirical literature on the effects of technological change on wages and employment, ${ }^{1}$ but the literature on the reverse question is much more limited. A few papers show that labor market conditions affect labor-saving technology adoption in agriculture (Hornbeck and Naidu, 2014, and Clemens, Lewis and Postel, 2018), or manufacturing (Lewis, 2011). Lordan and Neumark (2018) find that minimum wage hikes displace workers in automatable jobs. Unlike these papers our focus is on innovation instead of adoption. This matters because the economic drivers of innovation may differ from those of adoption: innovation may respond differently to macroeconomic variables such as wages; and knowledge spillovers are likely to play a greater role.

Regarding innovation, Acemoglu and Restrepo (2018b) find a positive correlation in

\footnotetext{
${ }^{1}$ See e.g. Autor et. al. (2003), Autor and Dorn (2013) or Gaggl and Wright (2017) for IT, Doms, Dunne and Totske (1997) for factory automation, Graetz and Michaels (2017) or Acemoglu and Restrepo (2020) for robots, Mann and Püttmann (2018) or Bessen, Goos, Salomons and van den Berge (2019) for broader measures of automation.
} 
cross-country regressions between aging and patenting in robotics and numerical control (though their main focus is on adoption). Our paper differs in three ways: first, we build a broader measure of automation innovation in machinery; second, we are interested in the effect of all wage variations not just those arising from demographic trends; and third and most importantly, we conduct our analysis at the firm level instead of the country-industry. Bena and Simintzi (2019) show that firms with a better access to the Chinese labor market decrease their share of process innovations after the 1999 U.S.-China trade agreement. ${ }^{2}$ Andersson, Karadja and Prawitz (2020) look at the effect of emigration to the US in the $19^{\text {th }}$ century in Sweden and find that more exposed municipalities experienced an increase in innovation (but they do not identify automation innovations). In a paper subsequent to ours, Danzer, Feuerbaum and Gaessler (2020) exploit German immigrant settlement policy to show that increases in labor supply discourage local automation innovation, while we exploit firm-level variation and focus on the effect of labor cost on global innovation.

A large literature shows that the direction of innovation is endogenous in other contexts (e.g. Acemoglu and Linn, 2004, and Popp, 2002). Here, we build on ADHMV, who use firm-level variations in gas prices to show that higher gas prices lead firms in the auto industry to engage more in clean and less in dirty innovations. ${ }^{3}$

In contemporaneous work, Mann and Püttmann (2020) use machine-learning techniques to classify automation patents and Webb (2020) uses a dictionary approach similar to ours to identify robot, software and artificial intelligence patents. We compare our approaches below.

Section 2 contains our first contribution: a classification of automation technologies. Section 3 introduces a simple model to motivate the analysis. Section 4 describes the data and our empirical strategy. Section 5 contains the results of the main analysis on the effect of wages on automation innovations. Section 6 discusses the event study of the Hartz reforms. Section 7 concludes. The Appendix provides additional robustness checks and details on our methodology.

\footnotetext{
${ }^{2}$ Process innovations and automation innovations are not the same: some process innovations reduce other costs than labor (say, materials costs) and many automation innovations are product innovations (a new industrial robot is a product innovation for its maker).

${ }^{3}$ Three other papers have used ADHMV's methodology: Noailly and Smeets (2015) on innovation in electricity generation, Coelli, Moxnes and Ulltveit-Moe (2020) on the effect of trade policy on innovation and Aghion, Bénabou, Martin and Roulet (2020) on the role of environmental preferences and competition in innovation in the auto industry. We methodologically extend this work by including country-year fixed effects and separating the foreign variables.
} 


\section{Classifying Automation Patents}

In this section, we describe the patent data and our method for classifying automation patents. We then show that our measure of automation predicts a decline in routine tasks (reproducing the analysis of Autor et. al., 2003).

\subsection{Our approach to classify patents}

Our goal is to identify automation innovations in machinery: that is innovations embedded in equipment goods, such as machine tools or robots, which allow for the replacement of workers in certain tasks. Non-automation innovations, in contrast, may improve energy efficiency, reduce the costs of producing certain machines or increase reliability. We employ a dictionary method on patent data and proceed in three steps: i) We use the existing literature to identify keywords related to automation. ii) For each technology category in machinery (based on the IPC and CPC codes in patent data), we compute the share of patents at the European Patent Office (EPO), which contain one of our automation keywords. We use this measure to classify technology categories as automation or not. iii) We then classify worldwide patents as automation or not depending on whether they belong to an automation technology category.

This strategy of first classifying technology categories and then patents has two advantages over classifying patents directly. First, it allows us to include non-EPO patents in our analysis, for which our main data source (PATSTAT) does not have the text. ${ }^{4}$ More generally, other researchers can now use our technology category classification to classify patents without text and future patents. Second, the IPC and CPC codes (henceforth $\mathrm{C} / \mathrm{IPC}$ codes $),{ }^{5}$ which we use to define our technology categories, are by themselves informative of the characteristics of patents. The particular wording of a patent is also a signal of these characteristics but patents are written in different styles, and rarely expand on the purpose of the invention, so that the same innovation can often be described with or without using our keywords. Conversely, if a patent uses one of our keywords but does not belong to any C/IPC code where this is common, the inclusion of this keyword is frequently uninformative about the nature of the innovation. That

\footnotetext{
${ }^{4}$ To give an idea of the increase in sample, over the period 1997-2011 there are 3.19 million patent families with patent applications in at least two offices (a condition we will impose in our main analysis). Among those only around 740,000 have an EPO patent with a description in English.

${ }^{5}$ The IPC is the International Patent Classification and the CPC the Cooperative Patent Classification used by the USPTO and the EPO. The CPC is an extension of the IPC and contains around 250,000 codes in its most disaggregated form.
} 
is, the wording of a given patent is a weak signal of whether that patent corresponds to automation but the combined wording of many patents gives a strong signal of whether a technological code corresponds to automation. Therefore, our strategy assumes that technology categories are a better signal of whether a patent is an automation patent or not than the presence of our keywords. Yet, as we do not know which technology categories correspond to automation, we use the text of a subset of patents to classify these first. As a matter of fact, the World Intellectual Property Organization (WIPO) offers on its website a simple tool based on a similar principle: a search engine allows one to identify up to 5 IPC codes most likely to correspond to a set of keywords using the text of the patents in its database.

Alternatively, we could have read and classified a subset of patents and then used machine-learning techniques to classify other patents or technology categories based on patent text. This is the procedure in Mann and Püttmann (2018), whose results we discuss in Section 2.4 and Appendix A.3. Relying on keywords instead of a training set of patents presents several advantages. First, manually classifying patents as automation is a difficult task which cannot be easily systematized and outsourced: often looking at a single patent in isolation is not enough, and one needs to look at several patents within the same technological group to find patterns suggesting that a patent is likely an automation patent. Second, patents are written in a technical language and do not primarily discuss the goal of an innovation, so that only a few words within the text are informative and a machine-learning algorithm would require a very large training set. Third, by using a few keywords instead of a large training set, our approach is more transparent, easily replicable and modifiable and, as researchers, we have fewer degrees of freedom since we pick most of our keywords from the literature.

\section{$2.2 \quad$ Patent data}

We use two patent databases maintained by the EPO. For most of our empirical analysis, we use the World Patent Statistical Database (PATSTAT) from Autumn 2018 which contains the bibliographical information of patents from 90 patent-issuing authorities (covering nearly all patents in the world) but not the text of individual patents. Since text analysis is essential to our approach, we supplement with the EP full-text database from 2018, which contains the full text of EPO patent applications.

PATSTAT allows us to identify "patent families", a set of patent applications across

different patent offices which represent the same innovation. For each patent family, we 
Table 1: Choice of automation keywords

\begin{tabular}{|c|c|c|}
\hline Keywords & Comments & Source \\
\hline Automat* & $\begin{array}{l}\text { Automation, automatization } \\
\text { or automat* at least } 5 \text { times } \\
\text { or (automat* or autonomous) with (secondary words or warehouse or operator or arm or } \\
\text { convey* or handling or inspect* or knitting or manipulat* or regulat* or sensor or storage } \\
\text { or store or vehicle system or weaving or welding) in the same sentence at least twice }\end{array}$ & $\begin{array}{l}\text { Own / Doms, } \\
\text { Dunne and Troske } \\
\text { (DDT) / Acemoglu } \\
\text { and Restrepo (AR) }\end{array}$ \\
\hline Robot* & Not surgical or medical & DDT and AR \\
\hline Numerical Control & CNC or numeric* control* or (NC in the same sentence as secondary words) & DDT and AR \\
\hline $\begin{array}{l}\text { Computer-aided design } \\
\text { and manufacturing }\end{array}$ & $\begin{array}{l}\text { Computer-aided/-assisted/-supported in the same patent as secondary words } \\
\text { CAD or (CAM and not "content addressable memory") in same sentence as secondary words }\end{array}$ & DDT \\
\hline Flexible manufacturing & & DDT \\
\hline $\begin{array}{l}\text { Programmable logic } \\
\text { control }\end{array}$ & Programmable logic control or [PLC and not (powerline or "power line")] & DDT \\
\hline $3 D$ printer & "3D print*" or "additive manufacturing" or "additive layer manufacturing" & Own \\
\hline Labor & Including laborious & Own \\
\hline Secondary words & Machine or manufacturing or equipment or apparatus or machining & \\
\hline
\end{tabular}

know the date of first application (which we use as the year of an innovation), the patent offices where the patent is applied for, the identity of the applicants and the inventors and the number of citations received by the patent family. To identify the technological characteristics of patents we use their C/IPC codes. Importantly each patent usually has several $\mathrm{C} / \mathrm{IPC}$ codes. The $\mathrm{C} / \mathrm{IPC}$ codes form a hierarchical classification systems. Certain types of technologies (for instance fossil fuel engines) can readily be identified to existing groupings of $\mathrm{C} / \mathrm{IPC}$ codes. Such a grouping does not exist for automation and our goal here is to create one.

\subsection{Choosing automation keywords}

To tie our hands, we choose most of our keywords from the automation technologies identified in Doms, Dunne and Troske (DDT, 1997) and Acemoglu and Restrepo (AR, 2018b) and complement with a few additional words as described below. ${ }^{6}$ In fact, most of our search terms (for simplicity "keywords") correspond to the co-occurrence of our several words in the same sentence or patent, or the repetition of these words a sufficient number of times. Table 1 describes the list of our search terms together with their origin.

\footnotetext{
${ }^{6}$ Doms, Dunne and Troske (1997) measure automation using the Survey of Manufacturing Technology (SMT) from 1988 and 1993 conducted by the US Census. The survey asked firms about their use of certain automation and information technologies. Acemoglu and Restrepo (2018b) include imports of automation technology and associate specific HS-categories from Comtrade with automation technology.
} 
We have eight categories of keywords. Five of these, robot*, numerical control, computer-aided design and manufacturing, flexible manufacturing and programmable logic control are automation technologies in DDT or AR. Simply applying these words may result in false positives. For instance "NC" can refer to either "numerical control" or "North Carolina". To address this issue, we require that these words are either in the same patent or the same sentence as a list of secondary words, such as machinery or equipment, which indicate that the text describes a machine. Furthermore, we add "automation" and "automatization". The stem "automat*" gather too many false positives such as "automatic transmission". We resolve this in two ways: either by restricting attention to patents where the frequency is 5 or more or by combining automat* with our secondary words or other words which largely come from technologies described in DDT or AR and often describe tasks (such as manipulat*, regulat* or inspect*). We count patents where automat* and one of these words appear in the same sentence at least twice. Finally, we add 3D printing, which was in its infancy when DDT was written, and "labor" which often indicates that an innovation reduces labor costs. The most important keywords are those associated with "automat*" (see Appendix A.2) and Section 5.6 shows that our main results are robust to only using those.

\subsection{Automation technology categories and patents}

Defining machinery $\mathrm{C} / \mathrm{IPC}$ codes. We base our classification on the set of EPO patent applications from 1978 till 2018 with a description in English (1,538,370 patent applications), which we denote $\Omega_{E P O}$. We use the keywords to associate technology categories, and not patents directly, to automation. These technology categories are defined as: 6-digit C/IPC codes, all pairs of 4-digit C/IPC codes and, inspired by Aschhoff et al. (2010), pairs combining the union of the 3 digit codes G05 and G06 with any 4-digit C/IPC codes. ${ }^{7}$ The code G05 corresponds to "controlling; regulating" and G06 to "computing; calculating; counting" and they use these combinations to identify advanced manufacturing technologies. We restrict attention to categories which contain at least 100 patents (we group 6-digit codes with the same 4-digit code and less than

\footnotetext{
${ }^{7}$ Technically, the structure of the C/IPC classification is as follows: C/IPC "classes" have 3 digit codes (for instance B25: "hand tools; portable power-driven tools; handles for hand implements; workshop equipment and manipulators"), "subclasses" have 4 digit codes (for instance B25J: "manipulators; chambers provided with manipulation devices"), main groups have 5 to 7 digit codes (for instance B25J 9: "programme-controlled manipulators"). In the following, we slightly abuse language and refer to classes, subclasses and main groups as 3 digit, 4 digit and 6 digit codes respectively.
} 
100 patents in $\Omega_{E P O}$ in common artificial 6 digit codes).

Our keywords are best associated with automation in equipment and we accordingly restrict attention to $\mathrm{C} / \mathrm{IPC}$ codes which belong to certain technological fields. There are 34 technological fields (see Figure A.1) and we focus on "machine tools", "handling", "textile and paper machines" and "other special machines" with some adjustments, which we refer to as "machinery" patents (we use machinery and equipment interchangeably). ${ }^{8}$ This leaves us with 1009 6-digit C/IPC codes. For pairs of 4 digit C/IPC codes or pairings of 4 digit $\mathrm{C} / \mathrm{IPC}$ codes with G05 or G06 we classify them as belonging to machinery if at least a 4 digit code belongs to that field.

Formally, a patent $p$ is associated with a set of $\mathrm{C} / \mathrm{IPC}$ codes $C_{p}$ recorded at a highly disaggregated level. Define the functions $S_{3}\left(C_{p}\right)$ which extracts the set of unique 3 digit codes in $C_{p} ; S_{4}\left(C_{p}\right)$ which extracts the set of unique 4 digit codes and $S_{6}\left(C_{p}\right)$ which extracts the set of unique 6-digit codes (grouping 6-digit codes with less than 100 patents in $\Omega_{E P O}$ at the 4 digit level). Further, define the function $m_{4}\left(c_{4}\right)$ which takes the value 1 if a 4 digit $\mathrm{C} / \mathrm{IPC}$ code belongs to the machinery technological fields and 0 otherwise and similarly $m_{6}\left(c_{6}\right)$ for a 6 -digit code. We then define the broad set of machinery technology categories of a patent $p, \widetilde{M T}_{p}$ as

$$
\begin{aligned}
\widetilde{M T}_{p}= & \left\{c_{6} \in S_{6}\left(C_{p}\right) \mid m_{6}\left(c_{6}\right)=1\right\} \\
& \cup\left\{\left\{c_{4}, c_{4}^{\prime}\right\} \mid c_{4}, c_{4}^{\prime} \in S_{4}\left(C_{p}\right) \wedge c_{4} \neq c_{4}^{\prime} \wedge\left(m_{4}\left(c_{4}\right)=1 \vee m_{4}\left(c_{4}^{\prime}\right)=1\right)\right\} \\
& \cup\left\{\left\{c_{3}, c_{4}\right\} \mid\left\{c_{3}, c_{4}\right\} \in\left\{S_{3}\left(C_{p}\right), S_{4}\left(C_{p}\right)\right\} \wedge m_{4}\left(c_{4}\right)=1 \wedge c_{3} \in\{G 05, G 06\}\right\} .
\end{aligned}
$$

We exclude technological categories with less than 100 patents in $\Omega_{E P O}$ and denote the remaining set $M T_{p}$. The overall set of machinery technology categories is $\mathcal{M T}=$ $\cup_{p \in \Omega_{E P O}} M T_{p}$.

Defining automation C/IPC codes. A patent is also associated with a text $T_{p}$, for each keyword category (automat*, robot, CNC, etc.) we define functions $k^{\text {automat* }}\left(T_{p}\right)$, $k^{\text {robot }}\left(T_{p}\right), k^{C N C}\left(T_{p}\right)$, etc. which take value 1 if one of the associated keyword is in the text

\footnotetext{
${ }^{8}$ We exclude F41 and F42 which correspond to weapons and ammunition and are in "other special machines". Otherwise drones and missiles show up as a highly automated technology. Moreover, we include $\mathrm{B} 42 \mathrm{C}$ which corresponds to machines for book production and $\mathrm{B} 07 \mathrm{C}$ which corresponds to machines for postal sorting as both correspond to equipment technologies and contain 6-digit codes with a high prevalence of automation keywords; the 6-digit code G05B19 which corresponds to "programmecontrol systems" and contains a large number of computer numerically controlled machine tool patents without $\mathrm{C} / \mathrm{IPC}$ from the machine tools technological field; and the 6-digit code B62D65 which deals with engine manufacturing even though the rest of the B62D code deals with the vehicle parts themselves. We verify that these additional codes do not qualitatively affect our results.
} 
Table 2: Examples of 6-digit C/IPC codes in machinery

\begin{tabular}{|c|c|c|c|c|c|c|c|c|}
\hline Code & $\begin{array}{l}\text { Description } \\
\text { Den }\end{array}$ & \# patents & Any & 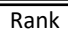 & Robot & Automat* & CNC & labor \\
\hline \multicolumn{9}{|c|}{ High prevalence } \\
\hline B25J5 & Manipulators mounted on wheels or on carriages & 504 & 0.91 & 1 & 0.87 & 0.27 & 0.01 & 0.1 \\
\hline B25J9 & Programme-controlled manipulators. & 2809 & 0.86 & 4 & 0.79 & 0.29 & 0.07 & 0.08 \\
\hline B23Q15 & $\begin{array}{l}\text { Automatic control or regulation of feed movement, } \\
\text { cutting velocity or position of tool or work. }\end{array}$ & 591 & 0.79 & 7 & 0.09 & 0.36 & 0.65 & 0.06 \\
\hline A01J7 & Accessories for milking machines or devices. & 395 & 0.77 & 9 & 0.62 & 0.52 & 0 & 0.1 \\
\hline G05B19 & Programme-control systems. & 7133 & 0.7 & 16 & 0.22 & 0.39 & 0.25 & 0.08 \\
\hline B65G1 & $\begin{array}{l}\text { Storing articles, individually or in orderly arrangement, } \\
\text { in warehouses or magazines }\end{array}$ & 1064 & 0.58 & 29 & 0.18 & 0.46 & 0.01 & 0.11 \\
\hline \multicolumn{9}{|c|}{ Low prevalence } \\
\hline B23P6 & Restoring or reconditioning objects. & 613 & 0.26 & 266 & 0.07 & 0.06 & 0.05 & 0.09 \\
\hline A01B63 & $\begin{array}{l}\text { Lifting or adjusting devices or arrangements for } \\
\text { agricultural machines or implements. }\end{array}$ & 264 & 0.24 & 306 & 0.01 & 0.2 & 0 & 0.04 \\
\hline B66D3 & Portable or mobile lifting or hauling appliances & 215 & 0.13 & 677 & 0.02 & 0.07 & 0 & 0.06 \\
\hline
\end{tabular}

and 0 otherwise. We define $k^{\text {any }}\left(T_{p}\right)=\max \left\{k^{\text {automat* }}\left(T_{p}\right), k^{\text {robot }}\left(T_{p}\right), k^{C N C}\left(T_{p}\right)\right.$, etc. $\}$ which takes value 1 if any of the automation keywords are present. For all machinery technology category $t \in \mathcal{M T}$, we define the prevalence of automation keywords $p(t)$ as the share of patents containing at least one of our keywords:

$$
p(t)=\frac{\sum_{p \in \Omega_{E P O}} 1_{t \in M T_{p}} k^{a n y}\left(T_{p}\right)}{\sum_{p \in \Omega_{E P O}} 1_{t \in M T_{p}}} .
$$

We similarly define the prevalence of specific keyword categories. We extensively checked the $\mathrm{C} / \mathrm{IPC}$ codes and sampled patents from each category to ensure that the procedure delivered reasonable results and adjusted the keywords accordingly. However, we never modified the classification after carrying out any of our regressions.

Table 2 gives some examples of 6 -digit C/IPC codes in machinery with their prevalence of automation keywords $p(t)$ and their rank according that measure. It also shows the prevalence of the most important subcategories (automat*, robots, CNC and labor). $\mathrm{C} / \mathrm{IPC}$ codes associated with robotics (B25J) have the highest prevalence numbers with up to $91 \%$ patents in B25J5 which contain at least one of the keywords. There are also codes associated with machine tools at the top of the distribution such as B23Q15 and codes associated with devices used in the agricultural sector such as A01J7. The last three $\mathrm{C} / \mathrm{IPC}$ codes are examples with a low prevalence of automation keywords: machine-tools and processes for repairing or reconditioning objects (B23P6), devices typically mounted on tractors (A01B63), and lifting or hauling appliances such as hoists 


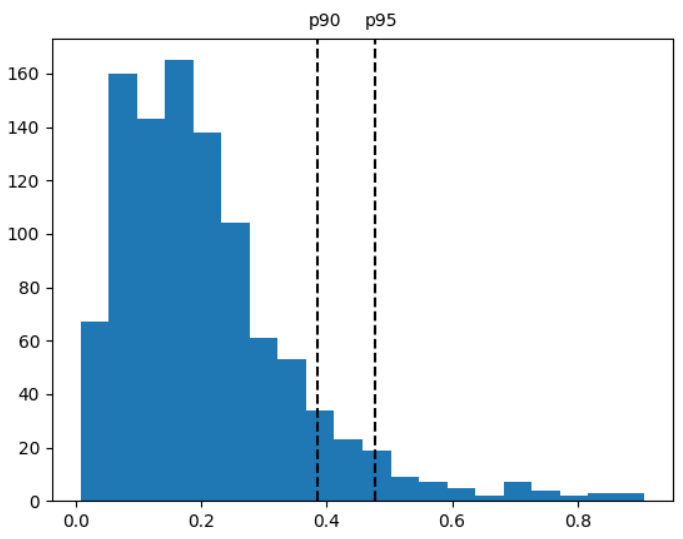

Figure 1: Prevalence of automation keywords for C/IPC 6 digit codes in machinery

(B66D3). The table also shows that the different sub-measures do not capture the same technologies: the robotic codes are ranked highly thanks to their share of patents with the word "robot", B23Q15 is high because a lot of patents contain words related to CNC, and B65G1, because a lot of patents contain words associated with automation directly.

Figure 1 gives the histogram of the prevalence of automation keywords for all C/IPC 6 digit codes in machinery. It shows that most $\mathrm{C} / \mathrm{IPC}$ codes have a low prevalence of automation keywords but a few codes have a very high value. Appendix A.2 gives additional statistics on the prevalence measures.

We define automation technology categories as those with a prevalence measure above some threshold. As our baselines, we choose thresholds at the $90^{\text {th }}$ and $95^{\text {th }}$ percentiles of distribution of the 6 digit code distribution (within machinery), which are given by 0.386 and 0.477 , respectively. ${ }^{9}$ Therefore a technology category $t$ belongs to the set of auto90 categories $T^{90}$ if $p(t)>0.386$ and to the set of auto95 category $T^{95}$ if $p(t)>0.477$. We then define a patent as an automation patent if it belongs to at least one automation technology category. That is we classify a patent family $p$ from the PATSTAT dataset $\Omega_{P A T S T A T}$ as an auto90 patent if $\exists t_{p} \in M T_{p}$ such that $t_{p} \in T^{95}$, and similarly for an auto90 patent. Note that close to $80 \%$ of automation patents are identified by the 6 digit alone (see Appendix A.2). ${ }^{10}$

\footnotetext{
${ }^{9}$ Choosing different thresholds is easy and we investigate how robust our results are in Section 5.6.

${ }^{10}$ In Appendix A.2.3, we show that the technology categories with a high prevalence of automation keywords remain the same throughout the period considered. In particular, the correlation between the
} 


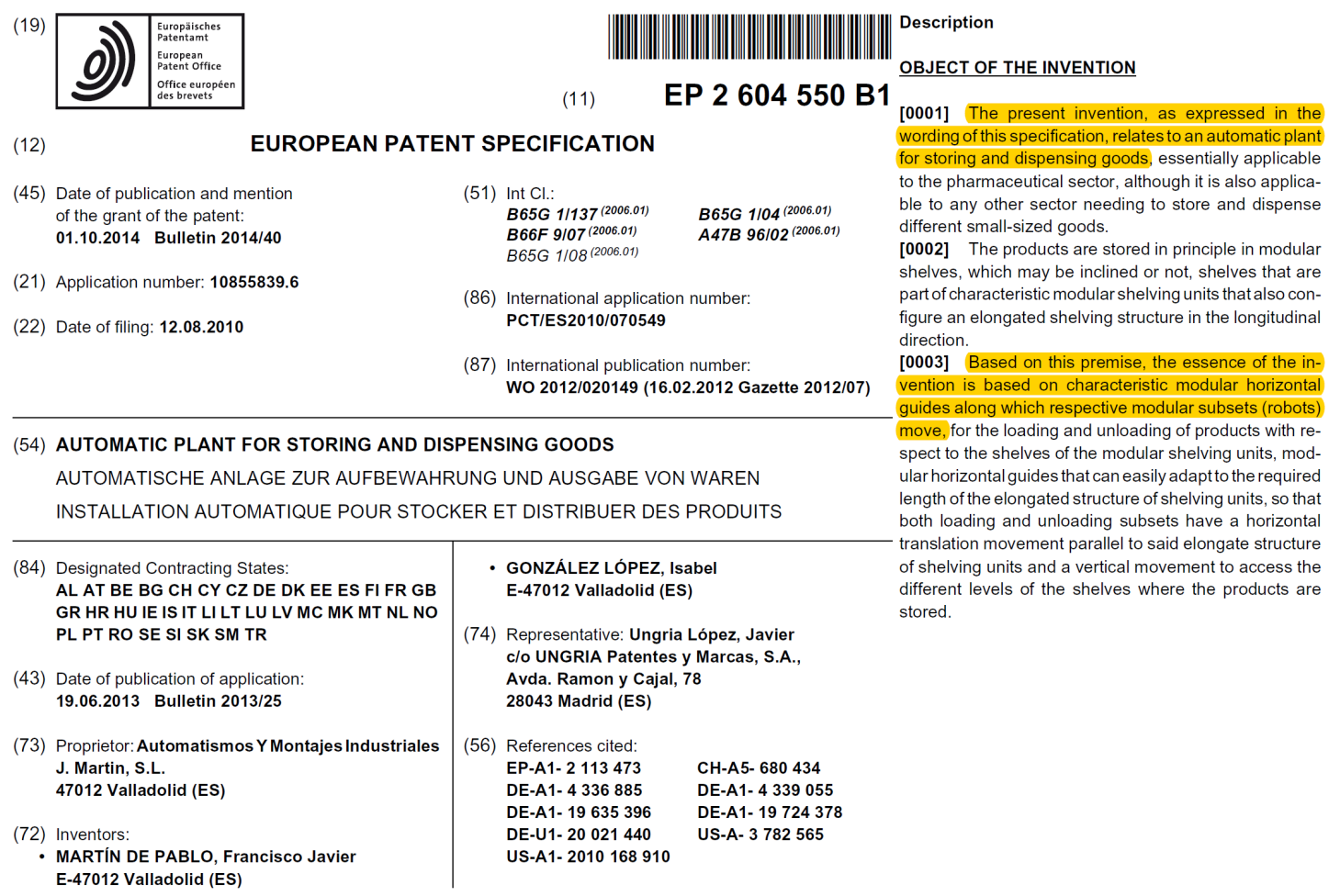

Figure 2: Example of an automation patent

Figure 2 shows an automated storage cabinet patent. We classify it as automation because it contains the 6 digit code B65G 1 which has a high prevalence measure $(0.58$, see Table 2). This patent itself contains several keywords: a sentence with the words "automatic" and "storing," and another sentence with "robot". Appendix Figure A.2 shows an automation patent of a similar storage cabinet that belongs to the same $\mathrm{C} / \mathrm{IPC}$ code but does not contain any keywords and still describes a labor-saving innovation. The supplemental material on our website provides more examples.

Comparison with Mann and Püttmann (2018). Mann and Püttmann (2018) also classify patents as automation versus non-automation. Our approaches differ in three ways. First, they classify all patents while we focus on machinery. Second, they manually classify a training set and use machine learning to classify US patents in a given period, while we identify technology categories thanks to a dictionary method, so that we (or others) can classify any patent in machinery. Third, they define as automation "a device that carries out a process independently of human intervention", while we seek to identify innovations that replace workers in existing tasks. Therefore, they classify prevalence measures computed for the first half of the sample and the second half is 0.92 . 
a number of patents related to elevators and printing machines as automation patents, which we do not (see Appendix A.3 where we compare the two approaches in details). ${ }^{11}$

\subsection{Trends in automation innovations}

We generally restrict attention to patent families with applications in at least two countries (referred to as biadic patents). Several studies (e.g. De Rassenfosse et al., 2013, and Dechezleprêtre, Ménière and Mohnen, 2017),) have shown that such patents are of higher quality than others. ${ }^{12}$ Focusing on biadic patents is also consistent with our empirical strategy which relies on firms' exposure to international markets.

Figure 3 plots the evolution of automation biadic patent families. Panel (a) shows that worldwide the share of automation patents in machinery slightly declined between the mid1980s (9.5\% in 1985 for auto95) and the mid1990s (7.6\% in 1994 for auto95) before increasing quickly (reaching 18.9\% in 2015 for auto95 in 2015). Appendix Figure A.3 shows that auto95 patents represent $2.7 \%$ of all patents in 2015 , a share that has doubled since 1997. It also reports the raw numbers of auto90 and auto95 patents. Figure 3.b shows the trends for auto95 by applicant nationality. The trend for Japan is somewhat distinct: it is initially considerably higher, but declines in the 80s and 90 s before picking up in the 2000s though slower than in the other countries. Germany has the highest automation share in 2015 .

\subsection{Automation and routine tasks}

Autor et. al. (2003) (henceforth ALM) show that computerization has been associated with a decrease in routine tasks at the industry level on U.S. data from 1960 to 1998. Here, we briefly analyze how our measure of automation relates to routinization, in part as a way to validate our measure of automation before focusing on our main topic: the effect of wages on induced automation innovation.

\footnotetext{
${ }^{11}$ Bessen and Hunt (2007) also use keywords to identify software patents. Webb (2020) focuses on matching three technologies (robotics, software and AI) to the occupations that they may replace. To identify the associated patents, he also uses keywords: he uses the algorithm of Bessen and Hunt (2007) for software patents, while robotics patents are defined as those with "robot" or "manipulat" in the title or abstract but exclude the CPC classes A61 or B01 (to avoid surgical robots). We instead focus on all automation innovation in machinery and since our classification is available at the C/IPC level, it can easily be used and extended by other researchers.

${ }^{12}$ We count applications and not granted patents because in certain patent offices, notably Japan, a patent is only formally granted if the rights of the applicant are challenged. To restrict attention to patent families of even higher quality, we carry out robustness checks where we use patent citations.
} 


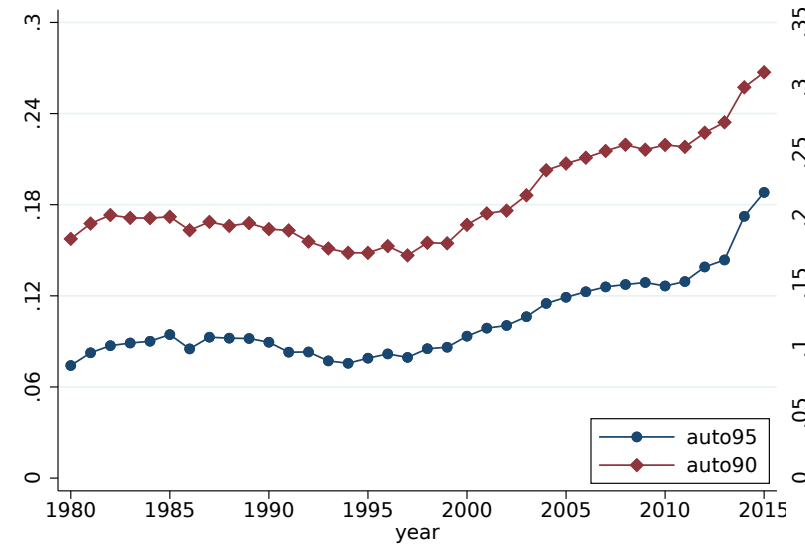

(a) Share of automation patents in machinery worldwide.

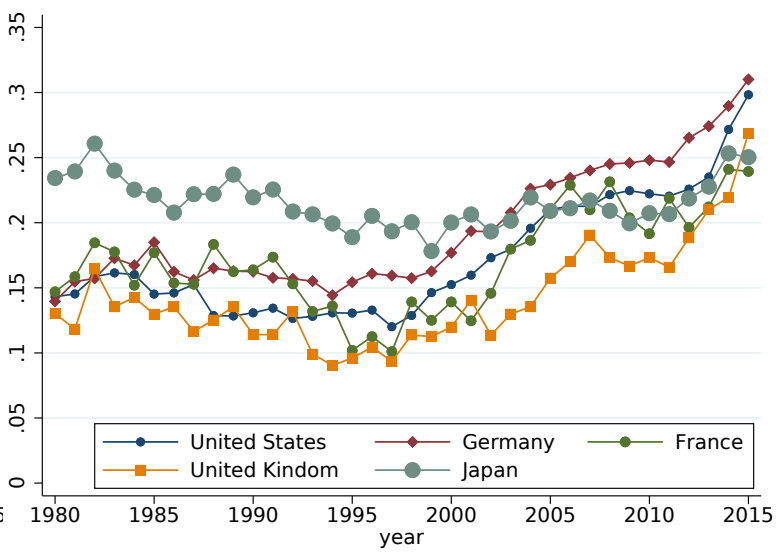

(b) Share of automation patents (auto95) in machinery by applicant's nationality.

Figure 3: Share of automation patents in machinery for biadic families.

As ALM, we run industry level regressions of the type:

$$
\Delta T_{j k \tau}=\beta_{0}+\beta_{C} \Delta C_{j}+\beta_{a u t} a u t_{j \tau} .
$$

$\Delta T_{j k \tau}$ represents the change in tasks of type $k$ in industry $j$ during period $\tau$ and $\Delta C_{j}$ is the measure of the change of computerization in sector $j$ (it is computed over the years 1984-1997 and used for all time periods $\tau$ ). aut $t_{j \tau}$ is our patent-based measure of automation intensity in sector $j$, period $\tau$. We do not first-difference this measure since patenting is already a measure of the flow of knowledge. We take our task measures directly from ALM, and therefore consider 5 types of tasks: nonroutine analytic, nonroutine interactive, routine cognitive, routine manual and nonroutine manual. $\Delta T_{j k \tau}$ is measured as 10 times the annual within-industry change in task input measured in percentile of the 1960 task distribution.

To construct $a u t_{j \tau}$, we allocate patents in machinery to their sector of use, focusing here on USPTO granted patents. Autor, Dorn, Hanson, Pisano and Shu (2020) match USPTO patents with firm-level data from Compustat and thereby provide detailed sectoral information for corporate patents. We use their data to create a (weighted) concordance table from C/IPC 4 digit codes to 4 digit SIC industries. This mapping can be used to allocate patents to sectors of invention. To get the sector of use, we then combine their mapping with the 1997 capital flow table from the BEA (the capital flow table is similar to an input output table but reports the flows in investment goods in- 


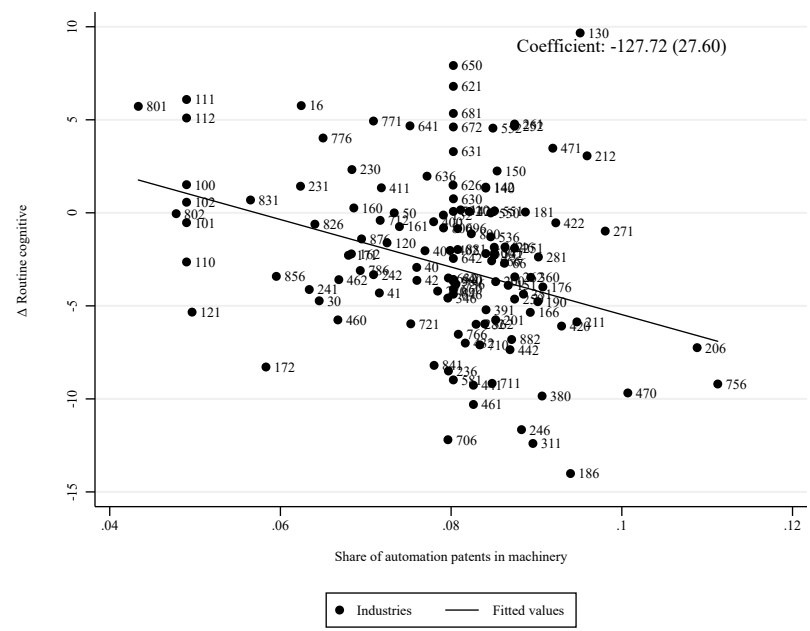

(a) Change in routine cognitive tasks and automation intensity

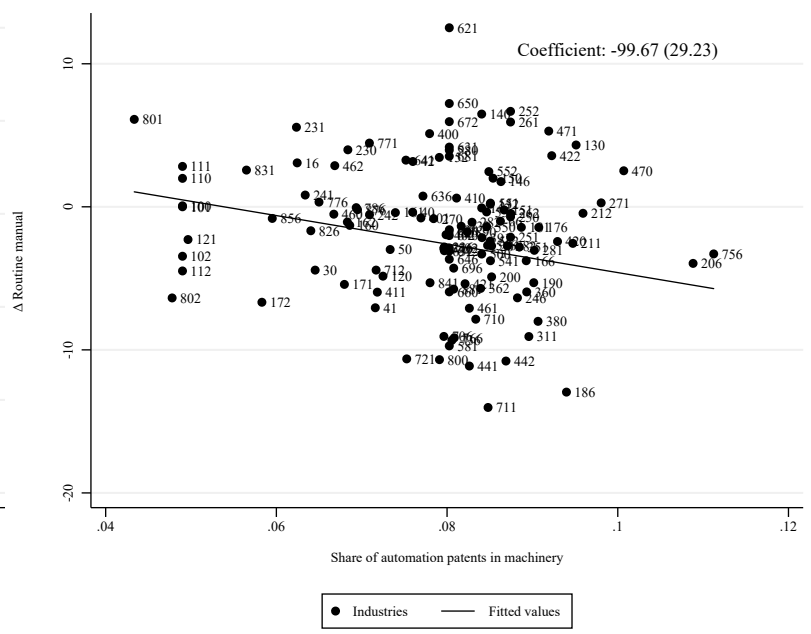

(b) Change in routine manual tasks and automation intensity

Figure 4: Scatter plots of routine tasks changes and automation intensity (auto 95) in 19801998 in the United States. The list of sectors is given in Table A.24

stead of intermediate inputs). For each sector $j$ and period $\tau$, we compute $a u t_{j \tau}$ as the share of automation patents among machinery patents applied for during this period. We consider 4 time periods: 1970-1980, 1980-1990 and 1990-1998 and the joint time period 1980-1998. We restrict attention to sectors with at least 50 machinery patents over the period. We can then measure automation intensity for 124 sectors in 1980-1998. Our automation measure auto95 is only weakly correlated with computerization with a coefficient of 0.17 (and -0.19 when we weigh industries by employment). See Appendix A.4 for further details on the data.

Figure 4 provides simple scatter plots of the changes in routine tasks and the share of automation patents in machinery over the years 1980-1998 (according to the auto95 definition). There is a clear relationship: sectors with a high share of automation patents experience a larger decline in routine cognitive and routine manual tasks. Given our focus on automation in machinery a decline in routine cognitive tasks might seem surprising at first sight, but several machines replace workers in tasks such as inspection and control (such an example is given in Figure A.2).

Table 3 reports the results of regressions (1) for the auto95 measure. Columns (3) and (4) show that sectors with a high share of automation patents in machinery experienced a large reduction in both cognitive and manual routine tasks in each decade (in the 90 s, the coefficient on routine manual tasks is non significant). For instance, Panel B 
Table 3: Correlation between changes in task intensity or skill ratio across sectors and automation (auto95)

\begin{tabular}{|c|c|c|c|c|c|}
\hline & $\begin{array}{c}(1) \\
\Delta \text { Nonroutine } \\
\text { analytic }\end{array}$ & $\begin{array}{c}\text { (2) } \\
\Delta \text { Nonroutine } \\
\text { interactive }\end{array}$ & $\begin{array}{c}(3) \\
\Delta \text { Routine } \\
\text { cognitive }\end{array}$ & $\begin{array}{c}(4) \\
\Delta \text { Routine } \\
\text { manual }\end{array}$ & $\begin{array}{c}(5) \\
\Delta \text { Nonroutine } \\
\text { manual }\end{array}$ \\
\hline \multicolumn{6}{|c|}{ Panel A: $1970-80, n=115$} \\
\hline $\begin{array}{l}\text { Share of automation } \\
\text { patents in machinery }\end{array}$ & $\begin{array}{l}-16.51 \\
(37.17)\end{array}$ & $\begin{array}{c}119.56^{\star *} \\
(50.18)\end{array}$ & $\begin{array}{l}-81.66^{*} \\
(46.02)\end{array}$ & $\begin{array}{l}-62.89 \\
(43.35)\end{array}$ & $\begin{array}{c}124.64^{* * *} \\
(43.09)\end{array}$ \\
\hline $\begin{array}{l}\Delta \text { Computer use } \\
1984-1997\end{array}$ & $\begin{array}{c}6.38 \\
(4.98)\end{array}$ & $\begin{array}{l}10.17 \\
(6.72)\end{array}$ & $\begin{array}{l}-8.04 \\
(6.16)\end{array}$ & $\begin{array}{l}-7.33 \\
(5.80)\end{array}$ & $\begin{array}{l}-4.91 \\
(5.77)\end{array}$ \\
\hline Intercept & $\begin{array}{c}0.90 \\
(2.29)\end{array}$ & $\begin{array}{l}-4.04 \\
(3.10)\end{array}$ & $\begin{array}{l}5.63^{\star *} \\
(2.84)\end{array}$ & $\begin{array}{l}5.64^{* *} \\
(2.67)\end{array}$ & $\begin{array}{l}-6.53^{* *} \\
(2.66)\end{array}$ \\
\hline$R^{2}$ & 0.02 & 0.06 & 0.04 & 0.03 & 0.08 \\
\hline Weighted mean $\Delta$ & 1.22 & 4.27 & -0.25 & 0.89 & -0.79 \\
\hline \multicolumn{6}{|c|}{ Panel B: 1980 - 90, n=115 } \\
\hline $\begin{array}{l}\text { Share of automation } \\
\text { patents in machinery }\end{array}$ & $\begin{array}{l}88.81^{* * *} \\
(29.21)\end{array}$ & $\begin{array}{l}82.67^{* *} \\
(36.90)\end{array}$ & $\begin{array}{c}-195.57^{\star * *} \\
(29.78)\end{array}$ & $\begin{array}{c}-138.69^{* * *} \\
(31.89)\end{array}$ & $\begin{array}{l}35.49 \\
(29.50)\end{array}$ \\
\hline $\begin{array}{l}\Delta \text { Computer use } \\
1984-1997\end{array}$ & $\begin{array}{c}18.84^{* * *} \\
(5.56)\end{array}$ & $\begin{array}{c}21.39^{* * *} \\
(7.02)\end{array}$ & $\begin{array}{c}-17.70^{* * *} \\
(5.67)\end{array}$ & $\begin{array}{c}-11.54^{*} \\
(6.07)\end{array}$ & $\begin{array}{l}-1.86 \\
(5.61)\end{array}$ \\
\hline Intercept & $\begin{array}{l}-8.39^{\star \star *} \\
(2.71)\end{array}$ & $\begin{array}{l}-5.64 \\
(3.42)\end{array}$ & $\begin{array}{c}16.62^{\star * \star} \\
(2.76)\end{array}$ & $\begin{array}{c}11.53^{* * *} \\
(2.96)\end{array}$ & $\begin{array}{l}-3.74 \\
(2.73)\end{array}$ \\
\hline$R^{2}$ & 0.14 & 0.10 & 0.30 & 0.15 & 0.02 \\
\hline Weighted mean $\Delta$ & 2.14 & 4.89 & -2.01 & -1.48 & -1.33 \\
\hline \multicolumn{6}{|c|}{ Panel C: 1990 - 98, n=115 } \\
\hline $\begin{array}{l}\text { Share of automation } \\
\text { patents in machinery }\end{array}$ & $\begin{array}{c}21.71 \\
(31.82)\end{array}$ & $\begin{array}{c}42.74 \\
(36.19)\end{array}$ & $\begin{array}{l}-77.53^{\star \star} \\
(36.65)\end{array}$ & $\begin{array}{l}-99.72^{\star *} \\
(38.65)\end{array}$ & $\begin{array}{c}40.21 \\
(26.37)\end{array}$ \\
\hline $\begin{array}{l}\Delta \text { Computer use } \\
1984-1997\end{array}$ & $\begin{array}{c}12.97^{\star *} \\
(5.36)\end{array}$ & $\begin{array}{c}16.30^{* * *} \\
(6.10)\end{array}$ & $\begin{array}{c}-16.91^{* * *} \\
(6.18)\end{array}$ & $\begin{array}{c}-29.51^{\star * *} \\
(6.51)\end{array}$ & $\begin{array}{l}9.40^{\star *} \\
(4.44)\end{array}$ \\
\hline Intercept & $\begin{array}{l}-1.63 \\
(2.83)\end{array}$ & $\begin{array}{l}-2.31 \\
(3.22)\end{array}$ & $\begin{array}{l}5.90^{*} \\
(3.26)\end{array}$ & $\begin{array}{l}9.86^{* * *} \\
(3.43)\end{array}$ & $\begin{array}{l}-5.28^{* *} \\
(2.34)\end{array}$ \\
\hline $\mathrm{R}^{2}$ & 0.05 & 0.06 & 0.08 & 0.17 & 0.05 \\
\hline Weighted mean $\Delta$ & 2.54 & 4.10 & -3.26 & -3.43 & -0.41 \\
\hline
\end{tabular}

Standard errors are in parentheses. Colums (1) to (5) of Panels A to $C$ each presents a separate OLS regression of ten times the annual change in industry-level task input between the endpoints of the indicated time interval (measured in centiles of the 1960 task distribution) on the share of automation patents in machinery (defined with the 95th percentile threshold) and the annual percentage point change in industry computer use during $1984-1997$ as well as a constant. In Column (6), the dependent variable is the ratio of high-skill (college graduates) to low-skill (highschool graduates and dropouts) workers. Estimates are weighted by mean industry share of total employment in FTEs over the endpoints of the years used to form the dependent variable. ${ }^{*} p<0.1 ;{ }^{* \star} p<0.05 ;{ }^{* \star *} p<0.01$ 
indicates that a $1 \mathrm{pp}$ increase in the share of automation patents is associated with a 2 and 1.4 centiles decrease in routine cognitive and manual tasks in the 80s. The standardized beta coefficients are larger than for computerization since they correspond to 2.7 and 1.9 centiles in routine cognitive and manual tasks versus 1.3 and 0.8 though the effect of computerization is larger in the $90 \mathrm{~s} .{ }^{13}$ We obtain similar results when we restrict attention to biadic patents. In Appendix A.4, we also get similar results but with a lower magnitude when we compute the share of automation patents with the auto90 measure. We also allocate patents to their sector of invention and include this measure as a control in our regressions. We still find a negative effect of the use of automation technologies on routine tasks.

Our classification of machinery patents as automation or non-automation is a prerequisite for our main empirical exercise where we focus on the effect of an increase in labor costs on the innovations of equipment producers. Importantly, given a mapping between $\mathrm{C} / \mathrm{IPC}$ codes and sectors, it can also deliver a measure of automation at a more detailed sectoral level than alternatives such as robotization. And we have now showed that this measure is uncorrelated with computer use but is associated with a reduction in routine tasks at the sectoral level.

\section{A Simple Model}

Before carrying out our empirical analysis, we present a simple model to clarify our argument. The model is motivated by the business structure of the largest automation innovators. In 2018, Siemens, the biggest innovator in our sample, had $31 \%$ of its workforce in Germany but only $14 \%$ of its revenues from there. Its strongest growing division was the Digital Factory Division which provides a broad range of automation technology to manufacturers across the globe. The annual report describes how "The Digital Factory Division offers a comprehensive product portfolio and system solutions for automation technologies used in manufacturing industries, such as automation systems and software for factory automation, industrial controls and numerical control systems, motors, drives and inverters and integrated automation systems for machine tools and production machines...". Note that this sentence includes a lot of our keywords. The report is centrally interested in how "Changes in customer demand [for automation technology by down-

\footnotetext{
${ }^{13}$ The employment-weighted standard deviation in the share of automation patents in the 80 s for the included industry is $1.4 \%$ and the mean $7.8 \%$, while the standard deviation for computerization is 0.07 . Meanwhile routine tasks decline by 2 and 1.5 centiles on average for these sectors.
} 
stream manufacturers] are strongly driven by macroeconomic cycles". Interestingly, it never mentions "cost of labor" as a reason for automation, but instead uses a number of euphemisms such as "increase competitiveness", "enhance efficiency", "improve cost position" and "streamline production". Siemens further discusses how such macroeconomic trends affect its $R \& D$ decisions.

We incorporate these business features into a model built on Hémous and Olsen (forthcoming). A manufacturing good is produced with a continuum of intermediate inputs according to the Cobb-Douglas production function $Y=\exp \left(\int_{0}^{1} \ln y(i) d i\right)$, where $y(i)$ denotes the quantity of intermediate input $i$. The manufacturing good is the numéraire. Each intermediate input is produced competitively with high-skill labor $\left(h_{1, i}\right.$ and potentially $h_{2, i}$ ), low-skill labor, $l_{i}$, and potentially machines, $x_{i}$, according to:

$$
y_{i}=h_{1, i}^{1-\beta}\left(\gamma(i) l_{i}+\alpha(i) \nu^{\nu}(1-\nu)^{1-\nu} x_{i}^{\nu} h_{2, i}^{1-\nu}\right)^{\beta}
$$

$\gamma(i)$ is the productivity of low-skill workers, $\alpha(i)$ is an index which takes the value 0 for non-automated intermediates and 1 for automated intermediates and $\nu$ and $\beta$ are parameters in $(0,1)$. Machines are specific to the intermediate input $i$. If a machine is invented, it is produced monopolistically, 1 for 1 with the final good so that the monopolist charges a price $p_{x}(i) \geq 1$. At the beginning of the period, for each nonautomated intermediate $i$, there is an innovator. The innovator creates a machine specific to intermediate $i$ with probability $\lambda$ if she spends $\theta \lambda^{2} Y / 2$ units of manufacturing good.

For an automated intermediate input $(\alpha(i)=1)$, the downstream producer is indifferent between using low-skill workers or machines together with high-skill workers in production whenever $w_{H}^{\nu} p_{x}^{1-\nu}=w_{L} / \gamma(i)$. Therefore, the machine producer is in "Bertrand competition" with low-skill workers. As a machine costs 1, the machine producer charges a price $p_{x}(i)=\max \left\{\left(w_{L} / \gamma(i)\right)^{\frac{1}{1-\nu}} w_{H}^{-\frac{\nu}{1-\nu}}, 1\right\}$, such that machines are used if $w_{L} / \gamma(i)>w_{H}^{\nu}$. Since the manufacturing good is produced according to a CobbDouglas production function, we get $p(i) y(i)=Y$ for all intermediates. We can then derive the profits of the machine producer as $\pi_{i}^{A}=\max \left(1-\left(\gamma(i) / w_{L}\right)^{\frac{1}{1-\nu}} w_{H}^{\frac{\nu}{1-\nu}}, 0\right) \nu \beta Y$.

In turn, at the beginning of the period, the potential innovator solves $\max \lambda \pi_{i}^{A}-$ $\theta \lambda^{2} Y / 2$, giving the equilibrium innovation rate $\lambda=\pi_{i}^{A} /(\theta Y)$. As a result, the number of automation innovations is equal to:

$$
\text { Aut }=\frac{\nu \beta}{\theta} \int_{0}^{1}(1-\alpha(i)) \max \left(\left(1-\left(\frac{\gamma(i)}{w_{L}}\right)^{\frac{1}{1-\nu}} w_{H}^{\frac{\nu}{1-\nu}}\right), 0\right) d i
$$


This expression is increasing in the low-skill wage $w_{L}$ and decreasing in the high-skill wage $w_{H}$. Intuitively, the incentive to replace low-skill workers with machines (and highskill workers) increases with low-skill wages, leading to a higher demand for machines. The reverse holds for high-skill wages. An upward shift in low-skill worker productivity, $\gamma(i)$, also reduces the number of automation innovations.

To contrast automation with other types of innovations, assume that the production of an intermediate takes place according to:

$$
y_{i}=\left(q_{i} m_{i}\right)^{\delta} h_{1, i}^{1-\beta-\delta}\left(\gamma(i) l_{i}+\alpha(i) \nu^{\nu}(1-\nu)^{1-\nu} x_{i}^{\nu} h_{2, i}^{1-\nu}\right)^{\beta}
$$

where $m_{i}$ denotes non-automation "Hicks" machines with quality $q_{i}$. Hicks machines are also produced one-for-one with the final good. Each period one innovator may improve on the available quality of Hicks machines for intermediate $i$ by a factor $\mu$ by investing in R\&D. If she spends $\theta_{m} \lambda_{m}^{2} Y / 2$ units of the final good, she is successful with probability $\lambda_{m}$. In that case, the innovator becomes the monopolistic provider of Hicks machine $i$ under the pressure of a competitive fringe which has access to the previous technology, and the technology diffuses after one period. Otherwise, the good is produced competitively. The previous analysis on automation innovations remains identical. A successful Hicks innovator can charge a mark-up $\mu$ leading to profits $\pi_{i}^{H}=\left(1-\mu^{-1}\right) \delta Y$. The innovation rate is then $\lambda_{m}=\left(1-\mu^{-1}\right) \delta / \theta_{m}$, so that the number of Hicks innovations is a constant given by $N$ on $A u t=\delta\left(1-\mu^{-1}\right) / \theta_{m}$. In contrast to automation innovations, the number of non-automation innovations is independent of low- or high-skill wages.

\section{Empirical Strategy and Data}

We now take the predictions of our model to the data. In this section, we present the regression framework and the data construction. Section 5 will discuss results and identification assumptions.

\subsection{Empirical strategy}

As mentioned above, innovators in automation technologies are often large companies (e.g. Siemens) which sell their automation equipment internationally. Following the logic of our model, the incentives of the downstream producers to adopt automation technology is determined by wages in their local market. As a result, the decision of 
innovators such as Siemens to pursue automation research in the first place depends on the wages that their potential customers face in different countries. ${ }^{14}$ To link patents with their owners, we use Orbis Intellectual Property. ${ }^{15}$

In our baseline regression, we assume that a firm's innovation in automation is given by the following Poisson specification:

$=\exp \left(\begin{array}{c}P A T_{A u t, i, t} \\ \beta_{w_{L}} \ln w_{L, i, t-2}+\beta_{w_{H}} \ln w_{H, i, t-2}+\beta_{X} X_{i, t-2}+\beta_{K a} \ln K_{A u t, i, t-2} \\ +\beta_{K o} \ln K_{\text {other }, i, t-2}+\beta_{S a} \ln S P I L L_{A u t, i, t-2}+\beta_{S o} \ln S P I L L_{o t h e r, i, t-2}+\delta_{i}+\delta_{j, t}\end{array}\right)+\epsilon_{i, t}$.

$P A T_{A u t, i, t}$ denotes the number of automation patents applied for by firm $i$ in year $t$. $w_{L, i, t-2}$ and $w_{H, i, t-2}$ denote the average low-skill and high-skill wages (more generally labor costs) faced by the customers of firm $i$ at time $t-2$ (we explain below how we proxy for them). Section 3 predicts that $\beta_{w_{L}}>0$ : an increase in the average lowskill wage faced by the customers of firm $i$ leads firm $i$ to undertake more automation innovations. It also predicts that $\beta_{w_{H}}<0$ since high-skill workers are complements to machines. $X_{i, t}$ represents a vector of additional controls (average GDP per capita, GDP gap and labor productivity). Labor productivity can capture technology or human capital shocks in the country where machines may be sold, GDP per capita can capture similar shocks but also demand shocks and the GDP gap business cycles fluctuations and changes in demand.

Ideally, one may want to measure the cost of labor for automatable tasks or occupations (as identified by Webb, 2000, for instance) instead of low-skill and high-skill workers. Unfortunately, in the absence of good international occupational labor costs data, we cannot pursue this approach. Insofar as low-skill and middle-skill workers are those whose tasks have been more intensely automated, our low-skill wage measure can be used as a proxy for the cost of automatable tasks. This proxy will be particularly good

\footnotetext{
${ }^{14}$ If the automation innovation is internal to the firm, then the argument follows if one interprets the innovator's customers as the different downstream production sites of the same firm.

${ }^{15}$ For companies in the same business group, $R \& D$ decisions could happen at the group level, though treating a group as one agent is often too aggressive (for instance because subsidiaries might be in different sectors). Therefore, for firms within the same business group, we normalize company names by removing non-firm specific words such as country names or legal entity types and then merge firms with the same normalized name. All other firms are treated as separate entities. Therefore, Siemens S.A., Siemens Ltd. or Belgian Siemens S.A. are merged, but Primetals Technologies Germany Gmbh which belongs to the same group remains a separate entity in our regressions.
} 
if labor markets are flexible across occupations within education groups or if the labor shocks which move low-skill wages affect low-skill workers similarly across occupations. Otherwise, our use of a noisy measure should result in downward bias.

Following ADHMV, we include controls for knowledge stocks at the firm and country level. $K_{A u t, i, t-2}$ and $K_{\text {other }, i, t-2}$ denote the stocks of knowledge in automation and in other technologies of firm $i$ at time $t-2$. These knowledge stocks are computed using the perpetual inventory method. ${ }^{16} S P I L L_{A u t, i, t-2}$ and $S P I L L_{\text {other }, i, t-2}$ similarly denote the stocks of external knowledge (spillovers) in automation and in other technologies which firm $i$ has access to at time $t-2$ (we explain below how these are constructed). These controls ensure that we are not simply capturing the fact that some firms or countries are on different automation trends. $\delta_{i}$ are firm fixed effects. $\delta_{j, t}$ are industry-year fixed effects (in some specifications we only have year fixed effects). The industry $j$ of a firm is the industry of manufacturing and corresponds to its 2 digit industry in Orbis. Appendix Table A.2 gives the distribution of firms and patents across the main industries in our sample. Finally, $\epsilon_{i, t}$ is an error term. The right-hand side variables are lagged by 2 years in the baseline regressions to reflect the delay between changes in R\&D investments and patent applications - Section 5.6 considers alternative timing assumptions. ${ }^{17}$ We use the ppmlhdfe command from Correia, Guimaraes and Zylkin (2020), which allows to run Poisson regression models with high dimensional fixed effects.

\subsection{Macroeconomic data}

Our macroeconomic variables come primarily from the 2013 release of the World Input Output Tables, henceforth, WIOD (Timmer et al. 2015). The database contains information on hourly labor costs across groups of educational attainment (low-, middleand high-skill workers) for the manufacturing sector from 1995 to 2009 for 40 countries including all major markets (US, Japan, all EU countries of 2009, China, India, Brazil, Russia, etc.). We get similar data from the Swiss Federal Statistical Office to

\footnotetext{
${ }^{16}$ We use $\ln (1+K)$, a depreciation rate of $15 \%$ and a dummy for whether the knowledge stock is 0 .

${ }^{17}$ To control for firm-level fixed effects, our baseline specification uses the Hausman, Hall and Griliches (1984, HHG) method which is the count data equivalent to the within-group estimator. Technically, this method is inconsistent with equation (3) as it requires strict exogeneity and hence prevents the lagged dependent variable from appearing on the right-hand side (which it does through the knowledge stock $\left.K_{A u t, i, t-2}\right)$. Yet, we show in Section 5.6, that our coefficients of interest are not affected by Nickell's bias by either removing the stock control or by implementing the Blundell, Griffith and Van Reenen (1999) method, which uses the pre-sample average of the dependent variable to proxy for the fixed effect, in line with the patent literature.
} 
add Switzerland, a large source of patents, to our analysis. For our baseline regressions, we focus on labor costs in manufacturing but check that our results are robust to using labor costs in the entire economy. Although our measures cover all labor costs, we refer to those as wages for simplicity. From the same dataset, we obtain measures of labor productivity (as value added divided by hours) and producer price indices (PPI for the whole economy and manufacturing). We obtain exchange rate and GDP data from UNSTAT and compute the GDP gap to control for business cycles. ${ }^{18}$ All macroeconomic variables are deflated in the same way. In the baseline regression, we first deflate nominal values by the local PPI for manufacturing (indexed to 1995), and then convert everything into dollars using the average exchange rate for 1995 the starting year of our regressions. Appendix A.5 provides further details.

In the data, low-skill workers are defined as those without a high-school diploma or equivalent and high-skill workers as those with at least a college degree. Middleand low-skill wages are very highly correlated so one should interpret our low-skill wage variable as reflecting both. ${ }^{19}$

The countries with the highest low-skill wages (actually labor costs in manufacturing) in 2009 are Belgium, Sweden and Finland with \$41.9, \$42.2 and \$43.6 respectively (in 1995 dollars) and those with the lowest are India, Mexico and Bulgaria with $\$ 0.28$, $\$ 0.61$ and $\$ 0.71$, respectively. The corresponding number for the US is $\$ 13.7$. Table 4 summarizes these values and further shows that the ratio of high-skill to low-skill wages varies considerably across countries, even among those that have relatively similar lowskill wages. The skill-premium in the United States rose from 2.46 to 3.02 during this period while it slightly declined in Belgium from 1.56 to 1.46 .

\subsection{Computing firm's market-specific wages and spillovers}

Ideally, we would like to measure the wages paid by the (actual and potential) customers of automation innovators. Since we do not observe them, we build a proxy which is a weighted average of country-level wages where the weights reflect the market exposure of innovators. We define the average low-skill wage faced by a firm's customers $w_{L, i, t}$ as

\footnotetext{
${ }^{18}$ We use a HP filter with a smoothing parameter of 6.25 on $\ln (G D P)$ to get the trend, and the GDP gap is measured as the difference between $\ln (G D P)$ and its trend.

${ }^{19}$ For our baseline sample of firms, included in Table 6 below, the correlation between low-skill and middle-skill wages is 0.94 controlling for firm and industry-year fixed effects versus 0.6 for low-skill and high-skill wages. See Appendix Table A.3.
} 
Table 4: Low-skill wages and the skill-premium in manufacturing for selected countries

\begin{tabular}{|c|c|c|c|c|c|c|}
\hline \multirow[t]{2}{*}{ Country } & \multicolumn{2}{|c|}{$\begin{array}{c}\text { Low-skill wages } \\
(1995 \$)\end{array}$} & \multicolumn{2}{|c|}{$\begin{array}{c}\text { High-skill wages } \\
(1995 \$)\end{array}$} & \multicolumn{2}{|c|}{$\begin{array}{l}\text { Skill premium } \\
\text { (HSW/LSW) }\end{array}$} \\
\hline & 1995 & 2009 & 1995 & 2009 & 1995 & 2009 \\
\hline India & 0.19 & 0.28 & 0.89 & 1.38 & 4.79 & 4.98 \\
\hline Mexico & 0.89 & 0.61 & 3.46 & 2.56 & 3.90 & 4.21 \\
\hline Bulgaria & 1.29 & 0.71 & 4.27 & 1.60 & 3.32 & 2.25 \\
\hline United States & 11.57 & 13.67 & 28.42 & 41.23 & 2.46 & 3.02 \\
\hline Belgium & 29.50 & 41.89 & 45.98 & 61.24 & 1.56 & 1.46 \\
\hline Sweden & 19.92 & 42.16 & 34.44 & 55.92 & 1.73 & 1.33 \\
\hline Finland & 23.41 & 43.63 & 28.10 & 63.71 & 1.20 & 1.46 \\
\hline
\end{tabular}

Note: Wages data, taken from WIOD. The table shows manufacturing low-skill and high-skill wages (technically labor costs) deflated by (manufacturing) PPI and converted to USD using average 1995 exchange rates. Skill-premium is the ratio of high-skill to low-skill wages. The table shows the three countries with the lowest low-skill wages in 2009 , the three with the highest and the US.

$$
w_{L, i, t} \equiv \sum_{c} \omega_{i, c} w_{L, c, t}
$$

where $w_{L, c, t}$ is the low-skill wage in country $c$ at time $t$ and $\omega_{i, c}$ is the fixed weight of country $c$ for firm $i$. We use the same approach to compute average high-skill wages, productivity or GDP per capita. Firms have different exposure to different markets because of trade barriers, heterogeneous tastes of customers, or various historical accidents if exporting involves sunk costs. This is a shift-share measure. The weights are computed pre-sample to ensure that they are weakly exogenous as patent location could be influenced by innovation shocks. Since the weights are fixed, our identification relies on how country-level shocks affect firms differently. In fact, had we observed the wages of the customers of automation innovators, those would have suffered from reverse causality, and we would have used our measure as an instrument. Our regression should therefore be viewed as the reduced form of this instrumental approach. We discuss the recent literature on shift-share regressions in detail in Section 5.5. ${ }^{20}$

To measure the weights in the absence of sales data, we follow and expand on the methodology of Aghion et al. (2016, ADHMV). We use the firm's pre-sample history of patent filing as a proxy for its market exposure. A patent grants its holder the exclusive right to commercially exploit a technology in a specific country for a limited period of time and inventors must file a patent in each country where they wish to protect their

\footnotetext{
${ }^{20}$ As we keep the weights fixed we look at how wage changes in the countries where a firm already sells affect the firm's automation innovation. A different question would have been to analyze how wage changes affect a firm's decision to enter a new market. This is beyond the scope of this paper.
} 
technology. Patenting is costly: a firm needs to hire lawyers and possibly translators as well as pay the filing costs. Further, the publication of a patent can increase vulnerability to imitation and inventors are therefore unlikely to apply for patent protection in a country unless they are relatively certain of the potential market value for the technology (Eaton and Kortum, 1996). Indeed, empirical evidence suggests that inventors do not patent widely and indiscriminately, with the average invention only patented in two countries (see Dechezleprêtre et al., 2011).

We compute for each firm the fraction of its patents in machinery protected in each country $c$ for which we have wage data, $\tilde{\omega}_{i, c}$, during the pre-sample period 1970-1994. We restrict attention to patent families with at least one citation (not counting selfcitations) to exclude the lowest quality patents. See Appendix A.6 for details notably on EPO patents. Patenting indicates whether the firm intends to sell in that market. However, a patent in Belgium and one in the U.S. are unlikely to reflect the same market size. At the same time, a larger market attracts more firms so that the market size per firm will generally not grow 1 for 1 with country size. To account for this we weigh each market $c$ by $G D P_{0, c}^{0.35}$, where $G D P_{0, c}$ is the 5 year average GDP of country $c$ at the end of the pre-sample period. ${ }^{21}$ As a result, the weight of country $c$ for firm $i$ is given by:

$$
\omega_{i, c}=\frac{\tilde{\omega}_{i, c} G D P_{0, c}^{0.35}}{\sum_{c^{\prime}} \tilde{\omega}_{i, c^{\prime}} G D P_{0, c^{\prime}}^{0.35}} .
$$

We use alternative weighting schemes in Section 5.6.

ADHMV verify that a similar method accounts well for the sales distribution of major auto manufacturers. Coelli, Moxnes and Ulltveit-Moe (2020) carry out a more systematic exercise and verify such a method accounts well for aggregate bilateral trade flows and firm exports across 8 country groups in a representative panel of 15,000 firms from 7 European countries (regressing patent weights on sales weights gives a coefficient of 0.89 with a s.e. of 0.008$)$. In supplemental material available on our web page, we also show that our patent weights correlate well with trade flows.

Given that knowledge spillovers have a geographical component, we use the location of firms' innovators to build a measure of the stock of knowledge to which a firm is exposed. We follow ADHMV and compute the stocks of automation patents and of

\footnotetext{
${ }^{21}$ Eaton, Kortum and Kramarz (2011) estimate the elasticity of French exports to GDP of the destination country to be 1 and the elasticity of the number of French exporters to be 0.65 . This gives an elasticity of the average export by firm of 0.35 . ADHMV use a power of 1 on GDP instead of 0.35 .
} 
Table 5: Descriptive statistics for firms in our baseline regression

\begin{tabular}{|c|c|c|c|c|c|c|c|}
\hline Variable & \multicolumn{2}{|c|}{ Auto95 } & \multicolumn{2}{|c|}{$\overline{~ A u t o 90}$} & \multirow[b]{2}{*}{ Weights } & $\overline{\text { Auto95 }}$ & Auto90 \\
\hline Automation pantents & per year & $1997-2011$ & per year & $1997-2011$ & & & \\
\hline Mean & 0.78 & 11.65 & 0.92 & 13.79 & Largest country & 0.47 & 0.46 \\
\hline Standard deviation & 3.97 & 52.60 & 4.71 & 62.55 & Second largest & 0.17 & 0.18 \\
\hline p50 & 0 & 2 & 0 & 2 & US & 0.21 & 0.21 \\
\hline p75 & 0 & 6 & 0 & 7 & Japan & 0.17 & 0.15 \\
\hline p90 & 1 & 19 & 2 & 22 & Germany & 0.2 & 0.21 \\
\hline p95 & 3 & 42 & 4 & 49 & France & 0.08 & 0.09 \\
\hline p99 & 13 & 184 & 15 & 216 & UK & 0.09 & 0.09 \\
\hline Number of firms & \multicolumn{2}{|c|}{3341} & \multicolumn{2}{|c|}{4903} & & & \\
\hline
\end{tabular}

other patents in each country. Then, for each firm, we build a weighted average of country-level knowledge stocks, where the weights correspond to the location of their innovators pre-sample in 1970-1994. ${ }^{22}$

\subsection{Descriptive statistics}

Our basic dataset consists of applicants who have applied to at least one biadic automation patent between 1997 and 2011, who have at least one patent prior to 1995 which can be used to compute weights, and who are not fully domestic (we exclude firms which have only patented in one country pre-sample). For the auto95 measure this corresponds to 3,341 firms, which are responsible for 35,803 or $58 \%$ of the total number of biadic auto95 innovations. Table 5 gives some descriptive statistics on the number of automation patents per year and the country weights for the firms in our sample. Over the period 1997-2011, the median firm in the sample filed 2 auto95 and auto90 patent applications. The distribution is very skewed and the $99^{\text {th }}$ percentile firm in the sample has filed 184 auto95 patents. The largest country for a given firm has on average a weight of 0.47 (for auto95). To ensure that our results are not driven solely by the largest country, which we refer to as the "home country" of a firm, we will include in some regressions home country-year fixed effects. The second largest country has on average a weight of 0.17 . The three countries with the largest weights on average are the United States, Germany and Japan. Appendix Table A.4 gives the list of the ten biggest automation patenters in our sample.

\footnotetext{
${ }^{22}$ The country stocks are built using the perpetual inventory method with a depreciation rate of $15 \%$. We add dummy variables indicating when the spillover stocks are zero.
} 


\section{Global Wages and Induced Automation}

We present our main results in three steps: First, our baseline regressions use the full variation of firm low-skill wages to estimate the effect of an increase in low-skill wages on automation innovations. Second, we use country-year fixed effects to isolate the contribution of foreign wages. Third, we contrast the results on automation innovations with those on other types of machinery innovations. The rest of the section discusses identification assumptions, contains robustness checks and additional results including on the minimum wage.

\subsection{Baseline results}

Table 6 contains our baseline results. The dependent variable is the number of automation (auto95) biadic patents. We use the years 1997-2011 for the dependent variable and, due to the lag structure, 1995-2009 for the independent variables. Recall that skilldependent wages are measured in the manufacturing sector and deflated by the PPI in that sector.

Table 6: Baseline regressions: effect of wages on automation innovations (auto95)

\begin{tabular}{|c|c|c|c|c|c|c|c|c|c|}
\hline \multirow[t]{2}{*}{ Dependent variable } & \multicolumn{9}{|c|}{ Auto95 } \\
\hline & (1) & (2) & (3) & (4) & (5) & (6) & (7) & (8) & (9) \\
\hline Low-skill wage & $\begin{array}{c}2.21^{* * *} \\
(0.51)\end{array}$ & $\begin{array}{c}2.83^{* * *} \\
(0.73)\end{array}$ & $\begin{array}{l}1.80^{* *} \\
(0.74)\end{array}$ & $\begin{array}{c}2.46^{* * *} \\
(0.75)\end{array}$ & $\begin{array}{c}2.32^{* * * *} \\
(0.81)\end{array}$ & $\begin{array}{c}2.54^{* * *} \\
(0.84)\end{array}$ & $\begin{array}{c}2.90^{* * *} \\
(0.78)\end{array}$ & $\begin{array}{c}2.67^{* * *} \\
(0.84)\end{array}$ & $\begin{array}{c}3.59^{* * * *} \\
(0.94)\end{array}$ \\
\hline High-skill wage & & $\begin{array}{l}-0.92 \\
(0.71)\end{array}$ & $\begin{array}{l}-0.88 \\
(0.67)\end{array}$ & $\begin{array}{c}-1.56^{* *} \\
(0.64)\end{array}$ & $\begin{array}{c}-1.73^{* *} \\
(0.72)\end{array}$ & $\begin{array}{c}-1.43^{* *} \\
(0.71)\end{array}$ & $\begin{array}{c}-2.22^{* * *} \\
(0.72)\end{array}$ & $\begin{array}{c}-2.61^{* * *} \\
(0.79)\end{array}$ & $\begin{array}{l}-1.52^{*} \\
(0.80)\end{array}$ \\
\hline Stock automation & & & $\begin{array}{c}-0.13^{* *} \\
(0.05)\end{array}$ & $\begin{array}{c}-0.13^{* * * *} \\
(0.05)\end{array}$ & $\begin{array}{c}-0.13^{* * *} \\
(0.05)\end{array}$ & $\begin{array}{c}-0.13^{* * *} \\
(0.05)\end{array}$ & $\begin{array}{c}-0.15^{* * *} \\
(0.05)\end{array}$ & $\begin{array}{c}-0.15^{* * *} \\
(0.05)\end{array}$ & $\begin{array}{c}-0.15^{* * *} \\
(0.05)\end{array}$ \\
\hline Stock other & & & $\begin{array}{c}0.63^{* * *} \\
(0.06)\end{array}$ & $\begin{array}{c}0.64^{* * * *} \\
(0.05)\end{array}$ & $\begin{array}{c}0.64^{* * * *} \\
(0.05)\end{array}$ & $\begin{array}{c}0.64^{* * *} \\
(0.05)\end{array}$ & $\begin{array}{c}0.65^{* * *} \\
(0.05)\end{array}$ & $\begin{array}{c}0.65^{* * *} \\
(0.05)\end{array}$ & $\begin{array}{c}0.65^{* * *} \\
(0.05)\end{array}$ \\
\hline GDP gap & & & & $\begin{array}{l}-3.30 \\
(2.52)\end{array}$ & $\begin{array}{l}-3.50 \\
(2.59)\end{array}$ & $\begin{array}{l}-3.00 \\
(2.65)\end{array}$ & $\begin{array}{l}-4.30^{*} \\
(2.57)\end{array}$ & $\begin{array}{l}-4.82^{*} \\
(2.66)\end{array}$ & $\begin{array}{l}-2.69 \\
(2.74)\end{array}$ \\
\hline Labor productivity & & & & & $\begin{array}{c}0.40 \\
(0.92)\end{array}$ & & & $\begin{array}{c}0.91 \\
(0.92)\end{array}$ & \\
\hline GDP per capita & & & & & & $\begin{array}{l}-0.31 \\
(1.14)\end{array}$ & & & $\begin{array}{l}-1.94 \\
(1.29)\end{array}$ \\
\hline Spillovers automation & & & & & & & $\begin{array}{l}0.60^{*} \\
(0.31)\end{array}$ & $\begin{array}{l}0.63^{* *} \\
(0.31)\end{array}$ & $\begin{array}{l}0.76^{* *} \\
(0.32)\end{array}$ \\
\hline Spillovers other & & & & & & & $\begin{array}{l}-0.27 \\
(0.22)\end{array}$ & $\begin{array}{l}-0.32 \\
(0.22)\end{array}$ & $\begin{array}{c}-0.41^{*} \\
(0.24)\end{array}$ \\
\hline Fixed effects & $\mathrm{F}+\mathrm{Y}$ & $\mathrm{F}+\mathrm{Y}$ & $\mathrm{F}+\mathrm{Y}$ & $\mathrm{F}+\mathrm{IY}$ & $\mathrm{F}+\mathrm{IY}$ & $\mathrm{F}+\mathrm{IY}$ & $\mathrm{F}+\mathrm{IY}$ & $\mathrm{F}+\mathrm{IY}$ & $\mathrm{F}+\mathrm{IY}$ \\
\hline Observations & 50115 & 50115 & 50115 & 49174 & 49174 & 49174 & 49174 & 49174 & 49174 \\
\hline Firms & 3341 & 3341 & 3341 & 3329 & 3329 & 3329 & 3329 & 3329 & 3329 \\
\hline
\end{tabular}

Note: Marginal effects; Standard errors in parentheses. The independent variables are lagged by two periods. Estimation is done by conditional Poisson fixed effects regressions (HHG). All regressions include firm and year or yearindustry fixed effects. All regressions with stock variables (resp. spillover variables) include a dummy for no stock (resp. no spillover). Standard errors are clustered at the firm-level. ${ }^{*} p<0.1{ }^{* *} p<0.05 ;{ }^{* * *} p<0.01$ 
Column (1) shows the results with only firm and year fixed effects. A higher low-skill manufacturing wage for the customers of an innovating firm predicts more automation innovation. The estimated coefficient is an elasticity so that an increase of $1 \%$ in the low-skill wage is associated with $2.2 \%$ more automation patents. Column (2) introduces high-skill wages as a control. In all specifications, high-skill wages have a negative (though not always significant) coefficient. Column (3) adds controls for the firm's stock of knowledge: a higher stock of automation knowledge predicts less automation innovations. Column (4) adds industry-year fixed effects and controls for the GDP gap. Columns (5) and (6) add controls for labor productivity in manufacturing and GDP per capita. None of these macroeconomic controls have consistent significant effects. Columns (7) to (9) repeat columns (4) to (6) but include knowledge spillovers and find that firms which are exposed to more knowledge in automation technologies innovate more in automation. In all specifications, the coefficient on low-skill wages is highly significant with elasticities between 1.8 and 2.9 for columns (1) to (8) and a larger elasticity of 3.6 in column (9). From column (4) onwards, we also control for industryyear fixed effects (where the industry is that of the innovating firm).

In the baseline specification, we cluster at the firm-level to account for auto-correlation in errors. As firms in the same country might be affected by common shocks, we cluster standard errors at the home country (i.e. the country of largest weight) level in Appendix Table A.5. If anything, this tends to reduce the standard error on low-skill wages, a pattern that repeats itself throughout the specifications. ${ }^{23}$

\subsection{Country-year Fixed Effects and Foreign wages}

Country-level shocks which we have not controlled for may impact both wages and innovation, by affecting the cost of innovation or the demand for automation machines through other channels than wages. A tax reform in Germany, for instance, could affect both German low-skill wages and the incentive to innovate. Shocks that mainly affect firms through their home country can be captured through home country-year fixed effects in which case our estimation procedure relies on variation in foreign wages.

\footnotetext{
${ }^{23} \mathrm{~A}$ potential explanation for the negatively correlated error terms, is that a successful innovation by one firm reduces the innovation of its competitors as the market is already captured. In addition, standard errors may overstate confidence levels if the number of clusters is small or the size distribution of clusters is skewed. To address this, Appendix Table A.5 also includes p-values for low-skill wages using the BDM bootstrap-t approach of Cameron, Gelbach and Miller (2008). All coefficients remain strongly significant.
} 
Table 7: Country-year fixed effects

\begin{tabular}{|c|c|c|c|c|c|c|}
\hline \multirow[t]{3}{*}{ Dependent variable } & \multicolumn{6}{|c|}{ Auto95 } \\
\hline & \multicolumn{3}{|c|}{ Domestic+Foreign } & \multicolumn{3}{|c|}{ Foreign } \\
\hline & (1) & $(2)$ & (3) & (4) & (5) & (6) \\
\hline Low-skill wage & $2.21^{* *}$ & $2.55^{* *}$ & $3.56^{* * *}$ & $4.14^{* * *}$ & $5.08^{* * *}$ & $4.14^{* *}$ \\
\hline High-skill wage & $\begin{array}{c}(0.99) \\
-2.89^{* * *}\end{array}$ & $\begin{array}{c}(1.13) \\
-2.16^{* *}\end{array}$ & $\begin{array}{l}(1.24) \\
-1.98^{*}\end{array}$ & $\begin{array}{c}(1.31) \\
-4.29^{* * *}\end{array}$ & $\begin{array}{c}(1.54) \\
-2.95^{* *}\end{array}$ & $\begin{array}{c}(1.77) \\
-4.29^{* * *}\end{array}$ \\
\hline & $(0.94)$ & $(1.05)$ & $(1.05)$ & $(1.29)$ & $(1.46)$ & $(1.39)$ \\
\hline GDP gap & $\begin{array}{c}4.01 \\
(6.85)\end{array}$ & $\begin{array}{c}4.94 \\
(6.89)\end{array}$ & $\begin{array}{c}6.31 \\
(7.16)\end{array}$ & $\begin{array}{c}-0.72 \\
(4.49)\end{array}$ & $\begin{array}{c}1.29 \\
(4.84)\end{array}$ & $\begin{array}{l}-0.73 \\
(5.12)\end{array}$ \\
\hline Stock automation & $\begin{array}{c}-0.16^{* * *} \\
(0.05)\end{array}$ & $\begin{array}{c}-0.16^{* * *} \\
(0.05)\end{array}$ & $\begin{array}{c}-0.16^{* * *} \\
(0.05)\end{array}$ & $\begin{array}{c}-0.16^{* * *} \\
(0.05)\end{array}$ & $\begin{array}{c}-0.16^{* * *} \\
(0.05)\end{array}$ & $\begin{array}{c}-0.16^{* * *} \\
(0.05)\end{array}$ \\
\hline Stock other & $\begin{array}{c}0.66^{* * *} \\
(0.06)\end{array}$ & $\begin{array}{c}0.66^{* * *} \\
(0.06)\end{array}$ & $\begin{array}{c}0.66^{* * *} \\
(0.05)\end{array}$ & $\begin{array}{c}0.65^{* * *} \\
(0.05)\end{array}$ & $\begin{array}{c}0.65^{* * *} \\
(0.05)\end{array}$ & $\begin{array}{c}0.65^{* * *} \\
(0.05)\end{array}$ \\
\hline Spillovers automation & $\begin{array}{c}1.39^{* * *} \\
(0.47)\end{array}$ & $\begin{array}{c}1.38^{* * *} \\
(0.47)\end{array}$ & $\begin{array}{c}1.37^{* * *} \\
(0.47)\end{array}$ & $\begin{array}{c}1.35^{* * *} \\
(0.46)\end{array}$ & $\begin{array}{c}1.32^{* * *} \\
(0.46)\end{array}$ & $\begin{array}{c}1.35^{* * * *} \\
(0.47)\end{array}$ \\
\hline Spillovers other & $\begin{array}{c}-1.07^{* * *} \\
(0.36)\end{array}$ & $\begin{array}{c}-1.04^{* * *} \\
(0.37)\end{array}$ & $\begin{array}{c}-1.09^{* * *} \\
(0.36)\end{array}$ & $\begin{array}{c}-1.09^{* * *} \\
(0.35)\end{array}$ & $\begin{array}{c}-1.08^{* * *} \\
(0.35)\end{array}$ & $\begin{array}{c}-1.09^{* * *} \\
(0.35)\end{array}$ \\
\hline Labor productivity & & $\begin{array}{l}-1.68 \\
(1.76)\end{array}$ & & & $\begin{array}{l}-2.15 \\
(1.58)\end{array}$ & \\
\hline GDP per capita & & & $\begin{array}{l}-3.33^{*} \\
(1.88) \\
\end{array}$ & & & $\begin{array}{c}0.00 \\
(2.07) \\
\end{array}$ \\
\hline Fixed effects & $\mathrm{F}+\mathrm{IY}+\mathrm{CY}$ & $\mathrm{F}+\mathrm{IY}+\mathrm{CY}$ & $\mathrm{F}+\mathrm{IY}+\mathrm{CY}$ & $\mathrm{F}+\mathrm{IY}+\mathrm{CY}$ & $\mathrm{F}+\mathrm{IY}+\mathrm{CY}$ & $\mathrm{F}+\mathrm{IY}+\mathrm{CY}$ \\
\hline Observations & 48773 & 48773 & 48773 & 48773 & 48773 & 48773 \\
\hline Firms & 3324 & 3324 & 3324 & 3324 & 3324 & 3324 \\
\hline
\end{tabular}

Note: Marginal effects; Standard errors in parentheses. The independent variables are lagged by two periods. Estimation is done by conditional Poisson fixed effects regressions (HHG). All regressions include firm, industry-year, and country-year fixed effects. Columns (4) to (6) use normalized foreign macroeconomic variables. Normalized foreign low-skill wages are defined as the $\log$ of foreign low-skill wages interacted with a measure of the importance of foreign markets in the total wage. This measure is computed at the beginning of the sample period and equals the foreign weight times the foreign low-skill wage divided by total low-skill wages. Normalized foreign high-skill wages, labor productivity and GDP per capita are defined similarly. Normalized foreign GDP gap is the foreign GDP gap interacted with the foreign weight. See text for details. All regressions include dummies for no stock and no spillover. Standard errors are clustered at the firm-level. ${ }^{*} p<0.1 ; * * p<0.05 ;{ }^{* * *} p<0.01$

Moreover country-year fixed effects are useful to address reverse causality: a technology shock that leads German firms to introduce more automation innovations and therefore lower German wages is unlikely to affect non-German wages since each firm is small for foreign countries. Our identification assumption is then that foreign wages are exogenous to the automation innovation of the firm given our set of controls. We discuss a number of potential confounding factors below.

Columns (1) to (3) of Table 7 reproduce Columns (7) to (9) of Table 6 but add country-year fixed effects, where the country of a firm is still defined as the country with the largest weight (using the headquarters' location to define the home country gives similar results). We still obtain a positive effect of low-skill wages on automation innovations with similar elasticities (between 2.2 and 3.6).

Columns (4) to (6) go further and only consider the foreign component of wages (and of the other macroeconomic variables). To do so, we decompose total low-skill wages 
$w_{L, i, t}$ into their home and foreign components as $w_{L, i, t}=\omega_{i, D} w_{L, D, t}+\omega_{i, F} w_{L, F, t}$ where $\omega_{i, D}$ is the home weight, $w_{L, D, t}$ the home wage, $\omega_{i, F}=1-\omega_{i, D}$ the foreign weight and $w_{L, F, t}$ the average foreign wage. We use the normalized foreign low-skill wage which is defined as $\frac{\omega_{i, F} w_{L, F, 0}}{w_{L, i, 0}} \log w_{L, F, t}$. The ratio $\frac{\omega_{i, F} w_{L, F, 0}}{w_{L, i, 0}}$ captures the fact that more internationally exposed firms are more affected by foreign wages and is computed at the beginning of the sample - though we obtain similar results when we use the average value over the whole sample. This specification ensures that our coefficient can be interpreted as an elasticity on total wages: Since $d \log w_{L, i, t}=\frac{\omega_{i, D} w_{L, D, 0}}{w_{L, i, 0}} d \log w_{L, D, t}+\frac{\omega_{i, F} w_{L, F, 0}}{w_{L, i, 0}} d \log w_{L, F, t}$, an increase in the normalized low-skill wage by 0.01 corresponds to an increase in total wages by $1 \%$ (recall that we have firm fixed effects). Normalized foreign high-skill wages, GDP per capita and labor productivity are defined similarly (as GDP gap is already an average of logs, we directly interact the foreign variables with $\omega_{i, F}$ ). Once again we find a positive effect of low-skill wages on automation innovation, with somewhat larger elasticities between 4.1 and 5.1. High-skill wages are the only other macro variable with a consistently significant effect, which is negative between -2 and -4 .3. No other paper using the ADHMV methodology controls for country-year fixed effects and separates foreign wages.

Appendix Table A.6 reproduces the regressions of columns (7) to (9) in Table 6 and of Table 7 but for the auto90 measure of automation. The results are very similar but the coefficients on low-skill wages tend to be of a smaller magnitude, in line with auto95 being a stricter measure of automation. This also helps explain the magnitude of our elasticities in the previous tables: our analysis focuses on innovations with a high automation content (and therefore most likely to respond to an increase in wages) and one should not take our estimates directly to measure the average macro response of the economy to an increase in wages.

Skill-premium. In the previous regressions, the coefficients on low-skill and highskill wages are of a similar magnitude but opposite signs suggesting that a driver of automation innovations is the skill premium. Table 8 directly regresses automation innovation on the log of the inverse of the skill premium. The coefficient on the inverse skill premium is always of the same magnitude as that on low-skill wages in previous specifications and highly significant. To illustrate the magnitude of our coefficients and the effect of spillovers and stock variables, we run a simulation in Appendix A.7 where we uniformly and permanently decrease the global skill-premium by $10 \%$. This increases the average share of automation innovations in machinery by 4.8 p.p. over the time 
Table 8: Skill premium

\begin{tabular}{|c|c|c|c|c|c|c|c|c|c|}
\hline \multirow[t]{3}{*}{ Dependent variable } & \multicolumn{9}{|c|}{ Auto95 } \\
\hline & \multicolumn{6}{|c|}{ Domestic+Foreign } & \multicolumn{3}{|c|}{ Foreign } \\
\hline & (1) & $(2)$ & (3) & (4) & $(5)$ & (6) & (7) & (8) & (9) \\
\hline Low-skill / High-skill wages & $\begin{array}{c}2.49^{* * *} \\
(0.69)\end{array}$ & $\begin{array}{c}2.64^{* * *} \\
(0.69)\end{array}$ & $\begin{array}{c}2.48^{* * *} \\
(0.68)\end{array}$ & $\begin{array}{c}2.56^{* * *} \\
(0.87)\end{array}$ & $\begin{array}{c}2.40^{* * *} \\
(0.86)\end{array}$ & $\begin{array}{r}2.65^{* * *} \\
(0.87)\end{array}$ & $\begin{array}{c}4.25^{* * *} \\
(1.25)\end{array}$ & $\begin{array}{c}4.11^{* * *} \\
(1.22)\end{array}$ & $\begin{array}{c}4.24^{* * *} \\
(1.24)\end{array}$ \\
\hline GDP gap & $\begin{array}{l}-4.59^{*} \\
(2.55)\end{array}$ & $\begin{array}{l}-4.86^{*} \\
(2.57)\end{array}$ & $\begin{array}{l}-4.57^{*} \\
(2.57)\end{array}$ & $\begin{array}{c}4.24 \\
(6.77)\end{array}$ & $\begin{array}{c}4.67 \\
(6.71)\end{array}$ & $\begin{array}{c}5.02 \\
(6.83)\end{array}$ & $\begin{array}{l}-0.76 \\
(4.50)\end{array}$ & $\begin{array}{l}-0.25 \\
(4.56)\end{array}$ & $\begin{array}{l}-0.57 \\
(4.60)\end{array}$ \\
\hline Labor productivity & & $\begin{array}{c}0.96 \\
(0.64)\end{array}$ & & & $\begin{array}{l}-1.28 \\
(1.09)\end{array}$ & & & $\begin{array}{l}-0.43 \\
(0.72)\end{array}$ & \\
\hline GDP per capita & & & $\begin{array}{c}-0.04 \\
(0.72)\end{array}$ & & & $\begin{array}{l}-1.71 \\
(1.11)\end{array}$ & & & $\begin{array}{c}-0.14 \\
(0.88)\end{array}$ \\
\hline Stocks / Spillovers & Yes & Yes & Yes & Yes & Yes & Yes & Yes & Yes & Yes \\
\hline Fixed effects & $\mathrm{F}+\mathrm{IY}$ & $\mathrm{F}+\mathrm{IY}$ & $\mathrm{F}+\mathrm{IY}$ & $\mathrm{F}+\mathrm{IY}+\mathrm{CY}$ & $\mathrm{F}+\mathrm{IY}+\mathrm{CY}$ & $\mathrm{F}+\mathrm{IY}+\mathrm{CY}$ & $\mathrm{F}+\mathrm{IY}+\mathrm{CY}$ & $\mathrm{F}+\mathrm{IY}+\mathrm{CY}$ & $\mathrm{F}+\mathrm{IY}+\mathrm{CY}$ \\
\hline Observations & 49174 & 49174 & 49174 & 48773 & 48773 & 48773 & 48773 & 48773 & 48773 \\
\hline Firms & 3329 & 3329 & 3329 & 3324 & 3324 & 3324 & 3324 & 3324 & 3324 \\
\hline
\end{tabular}

Note: Marginal effects; Standard errors in parentheses. The independent variables are lagged by two periods. Estimation is done by conditional Poisson fixed-effects regressions (HHG). Columns (1)-(3) include firm and industry-year fixed effects. Columns (4)-(9) include firm, industry-year, and country-year fixed effects. Columns (7)-(9) compute the normalized foreign (log) inverse skill premium as the difference between the normalized $(\log )$ foreign low-skill wages and the normalized $(\log )$ foreign high-skill wages previously defined. In these columns, GDP gap, GDP per capita and labor productivity also correspond to their normalized foreign values. All regressions include dummies for no stock and no spillovers. Standard errors are clustered at the firm-level. ${ }^{*} p<0.1 ;{ }^{* *} p<0.05 ;{ }^{* *} p<0.01$

period, with 2.7 p.p. coming from the adjustment of stocks and spillovers.

\subsection{Non-automation innovations}

Is the effect of wages on automation innovations specific to automation or does it affect machinery patents in general? To answer this question, we now look at "placebo" regressions. Specifically, we consider the set of machinery patents and exclude any patent which has a technology category with a prevalence measure above the $60^{\text {th }}$ percentile of the distribution of $\mathrm{C} / \mathrm{IPC}$ 6-digit codes in the machinery (0.2091). We refer to these as "placebo machinery" innovations. We recompute knowledge stocks and spillover variables for these innovations ("own") and for all innovations except those ("other"). Table 9 reports the results. Columns (1) to (3) correspond to the baseline regressions with firm and industry-year fixed effects. Low-skill wages only have a positive and significant effect in column (3), but even in that case the coefficient is statistically significantly smaller than with automation (and loses significance with other deflators). Columns (4) to (6) repeat the same regressions but add country-year fixed effects and columns (7) to (9) focus on foreign wages. Neither low-skill wages nor any other macroeconomic control variable has an effect on placebo machinery innovations. The sign of low-skill wages even flip in columns (7) to (9). ${ }^{24}$ We view this exercise as validating both our empirical

\footnotetext{
${ }^{24}$ Conditioning on the $60^{\text {th }}$ percentile is not important and we obtain similar results with machinery innovations excluding auto95 or auto90. Further, replacing low-skill and high-skill wages with the skill
} 
Table 9: Non-automation innovations

\begin{tabular}{|c|c|c|c|c|c|c|c|c|c|}
\hline \multirow[t]{3}{*}{ Dependent variable } & \multicolumn{9}{|c|}{ Placebo Machinery } \\
\hline & \multicolumn{6}{|c|}{ Domestic+Foreign } & \multicolumn{3}{|c|}{ Foreign } \\
\hline & (1) & (2) & $(3)$ & (4) & (5) & (6) & (7) & (8) & (9) \\
\hline Low-skill wage & $\begin{array}{c}0.51 \\
(0.60)\end{array}$ & $\begin{array}{c}0.68 \\
(0.69)\end{array}$ & $\begin{array}{l}1.73^{* *} \\
(0.69)\end{array}$ & $\begin{array}{l}-0.07 \\
(0.80)\end{array}$ & $\begin{array}{l}-0.03 \\
(0.91)\end{array}$ & $\begin{array}{c}0.77 \\
(0.95)\end{array}$ & $\begin{array}{c}-0.64 \\
(1.19)\end{array}$ & $\begin{array}{l}-1.22 \\
(1.29)\end{array}$ & $\begin{array}{l}-0.80 \\
(1.23)\end{array}$ \\
\hline High-skill wage & $\begin{array}{l}-0.18 \\
(0.71)\end{array}$ & $\begin{array}{c}0.12 \\
(0.65)\end{array}$ & $\begin{array}{c}0.79 \\
(0.75)\end{array}$ & $\begin{array}{l}-0.27 \\
(0.97)\end{array}$ & $\begin{array}{l}-0.19 \\
(0.91)\end{array}$ & $\begin{array}{c}0.20 \\
(1.02)\end{array}$ & $\begin{array}{c}0.33 \\
(1.18)\end{array}$ & $\begin{array}{l}-0.39 \\
(1.30)\end{array}$ & $\begin{array}{c}0.24 \\
(1.33)\end{array}$ \\
\hline GDP gap & $\begin{array}{c}-3.39^{* *} \\
(1.51)\end{array}$ & $\begin{array}{l}-3.04^{*} \\
(1.59)\end{array}$ & $\begin{array}{l}-0.07 \\
(1.90)\end{array}$ & $\begin{array}{l}-1.15 \\
(3.61)\end{array}$ & $\begin{array}{l}-1.06 \\
(3.64)\end{array}$ & $\begin{array}{c}0.31 \\
(3.67)\end{array}$ & $\begin{array}{l}-2.72 \\
(2.62)\end{array}$ & $\begin{array}{l}-3.87 \\
(2.78)\end{array}$ & $\begin{array}{l}-3.02 \\
(2.76)\end{array}$ \\
\hline Stock own & $\begin{array}{l}0.03 \\
(0.04)\end{array}$ & $\begin{array}{c}0.03 \\
(0.04)\end{array}$ & $\begin{array}{c}0.03 \\
(0.04)\end{array}$ & $\begin{array}{c}0.03 \\
(0.04)\end{array}$ & $\begin{array}{c}0.03 \\
(0.04)\end{array}$ & $\begin{array}{c}0.03 \\
(0.04)\end{array}$ & $\begin{array}{c}0.03 \\
(0.04)\end{array}$ & $\begin{array}{c}0.03 \\
(0.04)\end{array}$ & $\begin{array}{c}0.03 \\
(0.04)\end{array}$ \\
\hline Stock other & $\begin{array}{c}0.55^{* * *} \\
(0.04)\end{array}$ & $\begin{array}{c}0.55^{* * *} \\
(0.04)\end{array}$ & $\begin{array}{c}0.55^{* * * *} \\
(0.04)\end{array}$ & $\begin{array}{c}0.56^{* * *} \\
(0.04)\end{array}$ & $\begin{array}{c}0.56^{* * *} \\
(0.04)\end{array}$ & $\begin{array}{c}0.56^{* * *} \\
(0.04)\end{array}$ & $\begin{array}{c}0.56^{* * *} \\
(0.04)\end{array}$ & $\begin{array}{c}0.57^{* * * *} \\
(0.04)\end{array}$ & $\begin{array}{c}0.56^{* * *} \\
(0.04)\end{array}$ \\
\hline Spillovers own & $\begin{array}{c}2.63^{* * *} \\
(0.40)\end{array}$ & $\begin{array}{c}2.66^{* * *} \\
(0.41)\end{array}$ & $\begin{array}{c}2.07^{* * * *} \\
(0.45)\end{array}$ & $\begin{array}{c}1.39^{* * *} \\
(0.50)\end{array}$ & $\begin{array}{c}1.39^{* * *} \\
(0.50)\end{array}$ & $\begin{array}{c}1.33^{* * *} \\
(0.50)\end{array}$ & $\begin{array}{c}1.39^{* * *} \\
(0.50)\end{array}$ & $\begin{array}{c}1.35^{* * *} \\
(0.50)\end{array}$ & $\begin{array}{c}1.40^{* * *} \\
(0.50)\end{array}$ \\
\hline Spillovers other & $\begin{array}{c}-2.31^{* * *} \\
(0.46)\end{array}$ & $\begin{array}{c}-2.32^{* * *} \\
(0.46)\end{array}$ & $\begin{array}{c}-1.79^{* * *} \\
(0.49)\end{array}$ & $\begin{array}{c}-1.32^{* *} \\
(0.54)\end{array}$ & $\begin{array}{c}-1.32^{* *} \\
(0.54)\end{array}$ & $\begin{array}{c}-1.26^{* *} \\
(0.54)\end{array}$ & $\begin{array}{c}-1.33^{* *} \\
(0.53)\end{array}$ & $\begin{array}{c}-1.28^{* *} \\
(0.54)\end{array}$ & $\begin{array}{c}-1.33^{* *} \\
(0.53)\end{array}$ \\
\hline Labor productivity & & $\begin{array}{l}-0.66 \\
(0.72)\end{array}$ & & & $\begin{array}{l}-0.17 \\
(1.10)\end{array}$ & & & $\begin{array}{l}1.18 \\
(1.14)\end{array}$ & \\
\hline GDP per capita & & & $\begin{array}{c}-3.08^{* * *} \\
(0.99)\end{array}$ & & & $\begin{array}{l}-1.85 \\
(1.35)\end{array}$ & & & $\begin{array}{c}0.27 \\
(1.35)\end{array}$ \\
\hline Fixed effects & $\mathrm{F}+\mathrm{IY}$ & $\mathrm{F}+\mathrm{IY}$ & $\mathrm{F}+\mathrm{IY}$ & $\mathrm{F}+\mathrm{IY}+\mathrm{CY}$ & $\mathrm{F}+\mathrm{IY}+\mathrm{CY}$ & $\mathrm{F}+\mathrm{IY}+\mathrm{CY}$ & $\mathrm{F}+\mathrm{IY}+\mathrm{CY}$ & $\mathrm{F}+\mathrm{IY}+\mathrm{CY}$ & $\mathrm{F}+\mathrm{IY}+\mathrm{CY}$ \\
\hline Observations & 114724 & 114724 & 114724 & 114478 & 114478 & 114478 & 114478 & 114478 & 114478 \\
\hline Firms & 7696 & 7696 & 7696 & 7693 & 7693 & 7693 & 7693 & 7693 & 7693 \\
\hline
\end{tabular}

Note: Marginal effects; Standard errors in parentheses. The independent variables are lagged by two periods. Estimation is done by conditional Poisson fixed-effects regressions (HHG). Columns (1)-(3) include firm and industry-year fixed effects, while (4)-(9) include firm, industry-year, and country-year fixed effects. In Columns (7)-(9) the macroeconomic variables are the normalized foreign variables previously defined. Stock and spillover variables are calculated with respect to the dependent variable (placebo machinery). Standard errors are clustered at the firm-level. ${ }^{*} p<0.1 ;{ }^{* *} p<0.05 ;{ }^{* * *} p<0.01$

approach and our measure of automation.

\subsection{Threats to identification}

The previous results establish a correlation between the development of automation technology by a firm and the wages faced by its customers. This relationships is persistent and stable to the inclusion of a number of control variables. Adding country-year fixed effects controls for unobservable shocks to the home country and make it unlikely that reverse causality is the driver. Ideally, we are interested in the effect of an increase in wages on the firm's propensity to introduce automation innovation (in the spirit of our model, we would like to identify $\partial \lambda / \partial w_{L}$ ). Of course, wages are an equilibrium outcome, but what matters for identification is that they are exogenous to the inventor. Labor market shocks in manufacturing, such as changes to labor supply or labor costs from regulation, demand for labor in other sectors or demographics, present ideal variation from this perspective. In Section 6, we will therefore focus on a specific labor-market premium in these regressions gives insignificant coefficients. (Results not shown). 
shock namely the Hartz reforms in Germany. Consequently, threats to identification arise from other foreign shocks which are correlated with wages and other drivers of automation. We now look at these in detail.

Foreign demand shocks in manufacturing. The biggest threat to identification comes from foreign demand shocks in manufacturing which might drive both wages and the demand for automation equipment. Some aspects of this have already been captured by the controls in Table 7 (GDP gap, GDP per capita and labor productivity). We look at additional controls in Table 10. i) Columns (1) and (5) further control for the share of the manufacturing sector built in the same manner as wages in regressions with countryyear fixed effects and either total wages or only foreign wages. The manufacturing share has no consistent effect by itself and does not alter the other coefficients significantly. ii) Conversely, increased offshoring in the foreign country might reduce both wages and the willingness to buy automation technology. We construct a measure of offshoring at the country-level based on the methodology of Timmer et al. (2014): the share of foreign value added in the gross value added in manufacturing. Then, as for other variables, we build a firm-specific value by taking a weighted average. As can be seen from Columns (2) and (6), this does not materially alter the coefficients. iii) In addition, the real interest rate covaries with the business cycle and is a potential important determinant of the cost of purchasing equipment. Columns (3) and (7) show that including the real yield on 10-year government bonds does not alter the coefficients much. ${ }^{25}$

Labor productivity shocks. We already control for overall labor productivity. An additional concern might come from low-skill specific labor productivity shocks such as $\gamma(i)$ in Section 3, but a positive shock to $\gamma(i)$ would be associated with higher wages and less automation innovation and would correspondingly bias our estimates downwards.

Innovation shocks. A recent period of higher than usual automation innovation might leave both wages and the incentive for further innovation low, creating a spurious positive correlation. To address this, we construct a measure of recent innovation in the same manner as we do for the low-skill wages: for each country we compute the number of automation innovations (from our set of firms or others) applied for in the last three years and then build firm-specific measures. We build a similar control for other innovations. The results in Columns (4) and (8) of Table 10 show that our results carry through (the low-skill wage coefficient in column (4) is just at the margin of significance).

Shocks to the inventing firm. Labor costs also affect the inventing firms through

\footnotetext{
${ }^{25}$ We get data for 21 countries (AT AU BE CA CH DE DK ES FI FR GB GR IE IT JP KR LU NL PT SE US) from the IMF and the OECD and deflate nominal yields using the manufacturing PPI.
} 
Table 10: Additional controls

\begin{tabular}{|c|c|c|c|c|c|c|c|c|}
\hline \multirow[t]{3}{*}{ Dependent variable } & \multicolumn{8}{|c|}{ Auto95 } \\
\hline & \multicolumn{4}{|c|}{ Domestic+Foreign } & \multicolumn{4}{|c|}{ Foreign } \\
\hline & (1) & (2) & (3) & (4) & (5) & (6) & (7) & (8) \\
\hline Low-skill wage & $\begin{array}{l}2.84^{* *} \\
(1.41)\end{array}$ & $\begin{array}{c}2.97^{* * *} \\
(1.15)\end{array}$ & $\begin{array}{l}2.49^{* *} \\
(1.14)\end{array}$ & $\begin{array}{c}2.01 \\
(1.24)\end{array}$ & $\begin{array}{c}4.58^{* * *} \\
(1.75)\end{array}$ & $\begin{array}{c}4.97^{* * *} \\
(1.50)\end{array}$ & $\begin{array}{c}5.06^{* * *} \\
(1.53)\end{array}$ & $\begin{array}{c}7.04^{* * *} \\
(1.72)\end{array}$ \\
\hline High-skill wage & $\begin{array}{l}-1.90 \\
(1.18)\end{array}$ & $\begin{array}{l}-1.46 \\
(0.99)\end{array}$ & $\begin{array}{l}-1.98^{*} \\
(1.04)\end{array}$ & $\begin{array}{l}-1.26 \\
(0.99)\end{array}$ & $\begin{array}{c}-3.24^{* *} \\
(1.48)\end{array}$ & $\begin{array}{c}-3.02^{* *} \\
(1.45)\end{array}$ & $\begin{array}{l}-2.79^{*} \\
(1.44)\end{array}$ & $\begin{array}{c}-3.97^{* * *} \\
(1.46)\end{array}$ \\
\hline GDP gap & $\begin{array}{c}4.30 \\
(6.78)\end{array}$ & $\begin{array}{c}5.04 \\
(6.87)\end{array}$ & $\begin{array}{c}5.83 \\
(6.98)\end{array}$ & $\begin{array}{c}7.02 \\
(6.78)\end{array}$ & $\begin{array}{c}2.88 \\
(5.32)\end{array}$ & $\begin{array}{c}1.99 \\
(5.27)\end{array}$ & $\begin{array}{c}2.07 \\
(4.82)\end{array}$ & $\begin{array}{c}3.21 \\
(4.93)\end{array}$ \\
\hline Labor productivity & $\begin{array}{l}-2.19 \\
(2.21)\end{array}$ & $\begin{array}{l}-2.69 \\
(1.67)\end{array}$ & $\begin{array}{l}-1.56 \\
(1.78)\end{array}$ & $\begin{array}{l}-2.45 \\
(1.85)\end{array}$ & $\begin{array}{l}-1.99 \\
(1.63)\end{array}$ & $\begin{array}{l}-1.71 \\
(1.54)\end{array}$ & $\begin{array}{l}-2.37 \\
(1.58)\end{array}$ & $\begin{array}{c}-5.14^{* *} \\
(2.09)\end{array}$ \\
\hline Manufacturing share & $\begin{array}{c}3.69 \\
(9.34)\end{array}$ & & & & $\begin{array}{l}-6.03 \\
(8.72)\end{array}$ & & & \\
\hline Offshoring & & $\begin{array}{l}10.33^{*} \\
(5.51)\end{array}$ & & & & $\begin{array}{l}-1.93 \\
(4.49)\end{array}$ & & \\
\hline Long-term interest rate & & & $\begin{array}{c}0.09 \\
(0.11)\end{array}$ & & & & $\begin{array}{l}-0.03 \\
(0.06)\end{array}$ & \\
\hline Recent innovation own & & & & $\begin{array}{c}-2.77^{* *} \\
(1.27)\end{array}$ & & & & $\begin{array}{c}1.24 \\
(0.92)\end{array}$ \\
\hline Recent innovation other & & & & $\begin{array}{l}1.79^{* *} \\
(0.77)\end{array}$ & & & & $\begin{array}{l}-0.34 \\
(0.79)\end{array}$ \\
\hline Stocks / Spillovers & Yes & Yes & Yes & Yes & Yes & Yes & Yes & Yes \\
\hline Fixed effects & $\mathrm{F}+\mathrm{IY}+\mathrm{CY}$ & $\mathrm{F}+\mathrm{IY}+\mathrm{CY}$ & $\mathrm{F}+\mathrm{IY}+\mathrm{CY}$ & $\mathrm{F}+\mathrm{IY}+\mathrm{CY}$ & $\mathrm{F}+\mathrm{IY}+\mathrm{CY}$ & $\mathrm{F}+\mathrm{IY}+\mathrm{CY}$ & $\mathrm{F}+\mathrm{IY}+\mathrm{CY}$ & $\mathrm{F}+\mathrm{IY}+\mathrm{CY}$ \\
\hline Observations & 48773 & 48773 & 48467 & 48773 & 48773 & 48773 & 48356 & 48773 \\
\hline Firms & 3324 & 3324 & 3299 & 3324 & 3324 & 3324 & 3294 & 3324 \\
\hline
\end{tabular}

Note: Marginal effects; Standard errors in parentheses. The independent variables are lagged by two periods. Estimation is done by conditional Poisson fixed-effects regressions (HHG). All columns include firm, industry-year, and country-year fixed effects. "Recent innovation own" denotes the log of a weighted average of automation innovations in the customer's countries in the last 3 years and "recent innovation other" the same value for all other innovations in these countries. In Columns (4) and (8), wages, GDP gap, labor productivity, and the long-term interest rate are recomputed using weights for the limited set of countries for which interest rates are available (see text). In columns (5)-(8) wages, GDP gap, and labor productivity correspond to their normalized foreign values as previously defined. Normalized foreign recent innovation is defined like the normalized foreign low-skill wages as the interaction between the foreign value and a measure of the importance of foreign markets in the total variable. This measure is computed at the beginning of the sample period and equals the foreign weight times the foreign recent innovation divided by total recent innovation. Normalized foreign manufacturing share, offshoring and long-term interest rates are defined similarly to the normalized foreign GDP gap as the interaction between their foreign component and the foreign weight. Standard errors are clustered at the firm-level. ${ }^{*} p<0.1 ;{ }^{* *} p<0.05 ;{ }^{* *} p<0.01$

its production and R\&D costs. Country-year fixed effects alleviate this concern as long as production and R\&D are concentrated in the home country. For production costs, if a firm serves a foreign market through offshoring instead of exporting, higher foreign low-skill wages in production would increase the price of machines and therefore bias our coefficient on low-skill wages toward 0. For R\&D costs, we can address the potential issue by re-building our firm-specific macro variable using weights based on the location of inventors instead of patent offices. Appendix Table A.7 shows that the coefficient on the baseline low-skill wages remains positive and significant but the coefficient on lowskill wages weighted by inventor weights is small and insignificant. These regressions provide an additional placebo test as they treat firms with the same macroeconomic shocks but weigh them differently.

Placebo. Throughout, our coefficient on low-skill wages should be compared to that from regressions with the placebo machinery innovations, which show persistently little 
effect from low-skill wages on innovation. Therefore, if our result on the effect of lowskill wages on automation innovations came from a bias, then that bias would have to be absent for other types of machinery innovations.

\subsection{Shift Share}

A recent literature addresses the identifying assumptions behind the shift-share set-up in linear regressions. In this respect, it is important for our identification strategy that the weights are pre-determined; that is firms do not choose where to patent based on their expectation of future wages. Appendix Table A.8 demonstrates that country-level growth rates in low- and high-skill wages between 1995 and 2000 have no predictive power on firm weights in 1995. Appendix Table A.9 shows that our results are robust to using weights computed only up to 1989 or to dropping the first 5 years of the regression. ${ }^{26}$

We interpret our results through the lens of Borusyak, Hull and Jaravel (2018) who show, in the language of our setting, that the random assignment of wage shocks conditional on weights can be sufficient for identification. The inference is valid if either there is a large number of countries (such that the Herfindahl index tends toward 0) affected by independent shocks (controlling for year and firm fixed effects); or the correlation of shocks within a country decays sufficiently rapidly that a large number of country-years is sufficient (see Appendix A2 in their paper). ${ }^{27}$ They advise practitioners to use appropriate controls to capture omitted variables. We follow this approach by including a large set of controls and country-year fixed effects in our regressions. They recommend applying the standard error correction of Adão, Kolesár and Morales (2019). ${ }^{28}$

Adão et. al. (2019) show that applications with the shift-share design often lead to an over-rejection of the null. In the language of our application, the problem arises when the residual errors of firms with similar country-distributions are correlated and is not solved by standard clustering. They derive a formula for correcting standard errors in an OLS, which we cannot use directly since we employ a Poisson estimator. Deriving

\footnotetext{
${ }^{26}$ Appendix Table A.9 also shows that the results are robust to dropping the earlier years from the weights. It looks at alternatives to premultiplying our patents weights with $G D P_{c}^{0.35}$ : with no multiplication, multiplying by $G D P$ or by total payment to low-skill workers raised to the power of $0.35,\left(w_{L} L\right)^{0.35}$, which may be a better measure of the potential market for technology designed to automate low-skill work. The results are very similar.

${ }^{27}$ The Herfindahl index is 0.13 and 0.09 when only foreign weights are included. At the country-year level, the corresponding values are 0.009 and 0.006 .

${ }^{28}$ Goldsmith-Pinkham, Sorking and Swift (2020) show that the shift-share setup is valid if the weights are exogenous. In our context, this would require that no unobserved shock-even one uncorrelated with low-skill wages-can affect automation through the weights, which would be a strong assumption.
} 
Table 11: Monte-Carlo simulations

\begin{tabular}{|c|c|c|c|c|c|c|c|c|c|}
\hline \multirow[t]{3}{*}{ Dependent variable } & \multicolumn{9}{|c|}{ Auto95 } \\
\hline & \multicolumn{6}{|c|}{ Domestic+Foreign } & \multicolumn{3}{|c|}{ Foreign } \\
\hline & $(1)$ & $(2)$ & $(3)$ & $(4)$ & $(5)$ & (6) & (7) & $(8)$ & $(9)$ \\
\hline \multirow[t]{2}{*}{ Low-skill wage } & 2.90 & $2.67^{*}$ & $3.59^{* *}$ & $2.21^{* * *}$ & $2.55^{* * *}$ & $3.56^{* *}$ & $4.14^{* *}$ & $5.08^{* *}$ & $4.14^{* * *}$ \\
\hline & {$[0.105]$} & {$[0.072]$} & {$[0.015]$} & {$[0.006]$} & {$[0.003]$} & {$[0.019]$} & {$[0.018]$} & {$[0.023]$} & {$[0.000]$} \\
\hline \multirow[t]{2}{*}{ High-skill wage } & $-2.22^{* *}$ & -2.61 & -1.52 & $-2.89^{* * * *}$ & $-2.16^{*}$ & $-1.98^{* *}$ & $-4.29^{*}$ & $-2.95^{* *}$ & -4.29 \\
\hline & {$[0.046]$} & {$[0.125]$} & {$[0.156]$} & {$[0.005]$} & {$[0.065]$} & {$[0.010]$} & {$[0.062]$} & {$[0.029]$} & {$[0.205]$} \\
\hline Stocks / Spillovers & Yes & Yes & Yes & Yes & Yes & Yes & Yes & Yes & Yes \\
\hline GDP gap & Yes & Yes & Yes & Yes & Yes & Yes & Yes & Yes & Yes \\
\hline Labor productivity & & Yes & & & Yes & & & Yes & \\
\hline GDP per capita & & & Yes & & & Yes & & & Yes \\
\hline Fixed effects & $\mathrm{F}+\mathrm{IY}$ & $\mathrm{F}+\mathrm{IY}$ & $\mathrm{F}+\mathrm{IY}$ & $\mathrm{F}+\mathrm{IY}+\mathrm{CY}$ & $\mathrm{F}+\mathrm{IY}+\mathrm{CY}$ & $\mathrm{F}+\mathrm{IY}+\mathrm{CY}$ & $\mathrm{F}+\mathrm{IY}+\mathrm{CY}$ & $\mathrm{F}+\mathrm{IY}+\mathrm{CY}$ & $\mathrm{F}+\mathrm{IY}+\mathrm{CY}$ \\
\hline Observations & 49174 & 49174 & 49174 & 48773 & 48773 & 48773 & 48773 & 48773 & 48773 \\
\hline Firms & 3329 & 3329 & 3329 & 3324 & 3324 & 3324 & 3324 & 3324 & 3324 \\
\hline
\end{tabular}

Note: Marginal effects; P-values in brackets. The independent variables are lagged by two periods. Estimation is done by conditional Poisson regressions fixed-effects (HHG). Columns (1)-(3) include firm and industry-year fixed effects. Columns (4)-(9) add countryyear fixed effects. Columns (7)-(9) use the normalized foreign macro variables previously defined. All regressions include controls for stocks and spillovers. P-values are computed by sampling with replacement the entire path of macroeconomic variables for each firm with 1000 draws. ${ }^{*} p<0.1 ; * * p<0.05 ; * * * p<0.01$

the corresponding correction for the Poisson estimator is beyond the scope of this paper. Instead we implement a Monte Carlo simulation similar to what they do and show that we do not have the same problem of over-rejection.

Specifically, we replicate the regressions of Columns (7) to (9) in Table 6 and of Table 7. For each firm we keep the automation activity, the stocks of innovations, the spillover variables, as well as the distribution of country-weights based on actual data. For each country, we sample with replacement the entire path of macroeconomics variables (wages, labor productivity, GDP per capita and GDP gap) from the existing set with 1000 draws. Table 11 reports the p-values of the coefficients on low-skill wages and high-skill wages based on the simulated distribution of coefficients. The p-values are not markedly different than the ones obtained assuming the standard normal distribution. In particular, the coefficients of interest on low-skill wages are significant at least at the $10 \%$ level (except in column 1 with a p-value of 0.105 ) and at the $2.5 \%$ level when we focus on foreign wages. In the language of Adão et al. (2019) the set of controls soaks up most country-specific shocks affecting the outcome variable and, consequently, no shift-share structure is left in the regression residuals.

Finally, Appendix Table A.10 checks that our results are not driven by a single country by sequentially excluding countries in our preferred set-up (with foreign wages and controlling for labor productivity). Excluding a country means that we treat it like the home country when computing normalized foreign wages. We also include the weight of the excluded country times a year dummy as a control. We successively remove the six 
largest countries by average weight (US, JP, DE, GB, FR, IT and ES). The coefficient on low-skill wages always remains negative and significant. ${ }^{29}$

\subsection{Additional Robustness Checks and Results}

Timing. We look at alternative lags for the dependent variables in Appendix Table A.11 (we keep a lag of 2 for the stock variables, otherwise the dependent variable would be included in the RHS in the lead and contemporaneous cases). The largest coefficient on low-skill wages is obtained for a 2 year lag. It remains relatively stable without country-year fixed effects, while it is more clearly centered around lag 2 with countryyear fixed effects. ${ }^{30}$ Of course, innovators would not be interested in wages 2 years in the past per se, but only inasmuch as they are indicative of future wages. This is our interpretation throughout of our regressions, with the 2 year lag corresponding roughly to the time spent between an effect on $R \& D$ and the first results materialized by a patent application. In Appendix Table A.13, we compute predicted future wages at time $t-2$ based on an $\mathrm{AR}(1)$ process with country-specific trends and find similar results.

Innovation types. We look at other definitions or subcategories of automation innovations in Table 12 which reproduces regressions similar to Column (5) of Table 7 with foreign wages and controlling for labor productivity. Column (1) verifies that the results are not driven by the codes that we added to the definition of the machinery technological field listed in footnote 8 (though, we still exclude the weapons categories). Column (2) presents a laxer definition of automation using the $80^{\text {th }}$ percentile of the distribution of the C/IPC 6 digit codes. The effect of low-skill wages is still positive but smaller than for auto90 or auto95. Columns (3) and (4) show that the results are similar for Automat*90 and Automat*80 patents. Automat*90 patents are those which belong to technological categories with a frequency of only the "automat*" group of keywords above the threshold used to define auto90 and automat*80, robot90 or CNC90 are defined analogously. By definition automat*80 patents are all auto80 but $91.5 \%$ of

\footnotetext{
${ }^{29}$ Goldsmith-Pinkham, Sorking and Swift (2020) advise carrying out a similar exercise by excluding countries with a large Rotemberg weight. Yet, this requires computing our macrovariables as weighted averages of log country-level variables instead of log of weighted averages of country-level variables. We checked that the six countries with the largest Rotemberg weights are the UK, FR, SE, DE, US and BE. Our results are also robust to excluding Belgium and Sweden.

${ }^{30}$ Appendix Table A.12 carries out placebo regressions where we regress automation innovation on 5,10 or 15 year leads of wages. We do not find a significant effect of leading low-skill wages (except a negative effect in one column). As expected, given the large number of coefficients a few of the other coefficients are significant but never in a systematic way across specifications.
} 
Table 12: Innovation categories

\begin{tabular}{|c|c|c|c|c|c|c|c|c|}
\hline \multirow[t]{2}{*}{ Dependent variable } & AutoX95 & 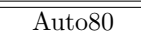 & Automat*90 & Automat*80 & Robot90 & Robot 80 & CNC90 & CNC80 \\
\hline & (1) & $(2)$ & (3) & (4) & (5) & (6) & (7) & (8) \\
\hline \multicolumn{9}{|l|}{ Foreign: } \\
\hline Low-skill wage & $\begin{array}{c}5.22^{* * *} \\
(1.59)\end{array}$ & $\begin{array}{l}2.62^{* *} \\
(1.29)\end{array}$ & $\begin{array}{c}6.90^{* * *} \\
(2.13)\end{array}$ & $\begin{array}{c}5.53^{* * *} \\
(1.94)\end{array}$ & $\begin{array}{l}5.83^{*} \\
(3.23)\end{array}$ & $\begin{array}{c}7.09^{* * *} \\
(2.49)\end{array}$ & $\begin{array}{c}-1.71 \\
(4.01)\end{array}$ & $\begin{array}{l}-1.15 \\
(3.10)\end{array}$ \\
\hline High-skill wage & $\begin{array}{l}-1.57 \\
(1.60)\end{array}$ & $\begin{array}{c}-1.82 \\
(1.33)\end{array}$ & $\begin{array}{c}-2.05 \\
(1.92)\end{array}$ & $\begin{array}{c}-1.96 \\
(1.77)\end{array}$ & $\begin{array}{c}-0.09 \\
(2.91)\end{array}$ & $\begin{array}{l}-3.27 \\
(2.32)\end{array}$ & $\begin{array}{c}5.02 \\
(5.40)\end{array}$ & $\begin{array}{c}0.89 \\
(3.59)\end{array}$ \\
\hline GDP gap & $\begin{array}{l}-0.07 \\
(4.50)\end{array}$ & $\begin{array}{c}1.01 \\
(3.03)\end{array}$ & $\begin{array}{c}7.76 \\
(5.08)\end{array}$ & $\begin{array}{c}3.90 \\
(4.64)\end{array}$ & $\begin{array}{c}4.83 \\
(8.19)\end{array}$ & $\begin{array}{c}0.21 \\
(6.77)\end{array}$ & $\begin{array}{c}-1.11 \\
(11.20)\end{array}$ & $\begin{array}{l}-0.03 \\
(9.34)\end{array}$ \\
\hline Labor productivity & $\begin{array}{c}-3.51^{* *} \\
(1.69)\end{array}$ & $\begin{array}{c}-1.09 \\
(1.22) \\
\end{array}$ & $\begin{array}{c}-5.16^{* * * *} \\
(1.87)\end{array}$ & $\begin{array}{c}-4.12^{* *} \\
(1.73)\end{array}$ & $\begin{array}{c}-6.71^{* *} \\
(2.73)\end{array}$ & $\begin{array}{c}-5.10^{* *} \\
(2.21)\end{array}$ & $\begin{array}{c}-3.20 \\
(4.85)\end{array}$ & $\begin{array}{c}-0.60 \\
(3.15)\end{array}$ \\
\hline Stocks / Spillovers & Yes & Yes & Yes & Yes & Yes & Yes & Yes & Yes \\
\hline Fixed effects & $\mathrm{F}+\mathrm{IY}+\mathrm{CY}$ & $\mathrm{F}+\mathrm{IY}+\mathrm{CY}$ & $\mathrm{F}+\mathrm{IY}+\mathrm{CY}$ & $\mathrm{F}+\mathrm{IY}+\mathrm{CY}$ & $\mathrm{F}+\mathrm{IY}+\mathrm{CY}$ & $\mathrm{F}+\mathrm{IY}+\mathrm{CY}$ & $\mathrm{F}+\mathrm{IY}+\mathrm{CY}$ & $\mathrm{F}+\mathrm{IY}+\mathrm{CY}$ \\
\hline Observations & 46980 & 96695 & 32738 & 48950 & 15927 & 23060 & 7609 & 13417 \\
\hline Firms & 3224 & 6494 & 2264 & 3331 & 1156 & 1619 & 582 & 987 \\
\hline
\end{tabular}

Marginal effects; Standard errors in parentheses. The independent variables are lagged by two periods. Estimation is done by conditional Poisson regressions fixed-effects (HHG). All regressions include firm fixed effects, industry-year and country-year fixed effects. AutoX95 excludes the C/IPC codes which we added when defining the machinery technological field. Auto80 lowers the threshold to define automation innovation to the 80 th percentile of the $\mathrm{C} / \mathrm{IPC} 6$ digit distribution. Automat* 90 and Automat*80 only count words associated with automat. Robot90 and Robot80 only count words associated with robot. CNC90 and CNC80 words associated with CNC. 90 and 80 refer to the threshold used to delimit patents which is the 90th or the 80th percentile of the distribution of automation keywords for 6 digit $\mathrm{C} / \mathrm{IPC}$ codes. The macroeconomic variables are the normalized foreign variables previously defined. Stocks and spillovers are computed with respect to the dependent variable. Standard errors are clustered at the firm-level. ${ }^{*} p<0.1 ;{ }^{* *} p<0.05 ;{ }^{* * *} p<0.01$

them are also auto90. Column (5) and (6) shows that our results extend to robot90 and robot80 patents (which are also all auto95). The results differ for CNC patents in columns (7) and (8) perhaps because the sample size is much smaller.

Minimum wage. Given its policy relevance, we also look at the effect of minimum wages using data on 22 countries in regressions where we replace low-skill wages with the minimum wage in Appendix Table A.14. ${ }^{31}$ We find a positive effect of the minimum wage on automation innovations but the coefficients tend to be smaller in the foreign wage regressions and in one specification the coefficient is insignificant. Therefore lowskill wages are a better predictor of automation than the minimum wage. This is not surprising: first, the minimum wage only captures part of the labor costs, second we focus on automation innovations that often happen in manufacturing where low-skill wages tend to be substantially above it, and third we lose nearly half of our countries. An analysis on automation in service industries might show a stronger relationship.

Long-difference. For most of our regressions, we follow the large patent literature and rely on the Poisson estimator, which best handles the count data nature of our dependent variable. In Appendix Table A.15, we conduct a long-difference estimation.

\footnotetext{
${ }^{31}$ We use data from the OECD. Importantly, not all countries have government-mandated minimum wages and for some countries, we follow the literature and use sectorally bargained minimum wages. See details in Appendix A.5. We do not use the minimum wage as an instrument for low-skill wages because it would be inconsistent: if low-skill wages are endogenous, then high-skill wages are likely endogenous too so that we would need a second instrument.
} 
To allow for zeros in the number of patents, we use the arcsinh transformation and we construct ten 5-year overlapping differences from our 15 years of data. Panel A focuses on firms which patented at least once over the time period considered (now 1995-2013), mirroring what a Poisson regression would do. We find a positive effect of low-skill wages and a negative effect of high-skill wages, although in some specifications the positive effect of low-skill wage is non-significant (in unreported regressions we find that the inverse skill premium always has a positive and significant effect). The diminished significance of low-skill wages reflects the noisy behavior of one-time patenters: Panel $B$ restricts attention to firms which have patented at least twice and recovers the same results as in our Poisson regressions: the change in low-skill wages has a large and significant positive effect on the change of automation innovations. These results suggest that automation responds to medium-run changes in wages.

Additional robustness checks. Our regressions include the stock of automation innovations and therefore may suffer from Nickell's bias. Appendix Table A.16 removes this variable or uses the usual method of Blundell, Griffith and van Reenen (1999)

method, which proxies for the fixed effect with the firm's pre-sample average of the dependent variable. We obtain very similar results.

Appendix Table A.17 investigates whether our results are robust when focusing on patents of higher quality and weighs patents by citations. We add to each patent the number of citations received within 5 years normalized by technological field and year of application. The results are weaker with total wages and country-year fixed effects but are very similar to the case without weighing patents in our preferred specification with foreign wages and country-year fixed effects.

Appendix Table A.18 shows that our results (using foreign wages and country-year fixed effects) are robust to using different deflators, converting in USD every year or replacing manufacturing wages by total wages. Firms of different sizes may be on different trends in automation innovation. In Appendix Table A.19, we group firms into four bins according to their number of automation patents in 1995, allow for bin-year fixed effects and find similar results.

\section{Event study: the Hartz reforms in Germany}

To complement our previous analysis on global wages, we now focus on one specific exogenous labor-market shock: the Hartz reforms. The Hartz reforms were a series of 
labor-market reforms in Germany designed from 2002 onward and implemented between January 1st 2003 and January 1st 2005. These reforms were the major macroeconomic shock in Germany at the time. They aimed at reducing unemployment and increasing labor-market flexibility by reforming employment agencies to provide better job-search assistance, deregulating temporary work, offering wage subsidies for hard-to-place workers, reducing or removing social contributions on low-paid jobs and reducing long-term unemployment benefits. The reforms have been widely credited with playing a major role in the remarkable performance of the German labor market since, in particular, for increasing labor supply and improving matching efficiency (see e.g. Krause and Uhlig, 2012). In line with the framework of Section 3, such reforms are predicted to reduce the incentive to automate low-skill labor by reducing labor costs (directly through social contribution and indirectly through an increase in labor supply) but also by allowing for more flexible contracts and reducing the expected cost of vacancies.

We use an analogous approach as before to measure innovation and firm's exposure to international markets, but we exclude German firms as they are likely to have been affected by the Hartz reforms through other channels than the labor costs faced by their customers. We run the following regression, over the years 1997-2014:

$$
P A T_{A u t, i, t}=\exp \left(\beta_{D E} \cdot \delta_{t} \omega_{i, D E}+\beta_{K a} \ln K_{A u t, i, t-2}+\beta_{K o} \ln K_{o t h e r, i, t-2}+\delta_{i}+\delta_{c, t}\right)+\epsilon_{i, t} .
$$

We keep a 2-year lag to the innovation stocks. As before $P A T_{A u t, i, t}$ is a count of automation patents, $K_{A u t, i, t-2}$ and $K_{\text {other }, i, t-2}$ represent firm knowledge stocks, $\delta_{i}$ a firm fixed effect and $\delta_{c, t}$ a country-year fixed effect. $\omega_{i, D E}$ is the fixed firm weight on Germany and $\delta_{t}$ is a set of year dummies (with 2005 as the excluded year). $\beta_{D E}$ is the full vector of coefficients of interest which determines by how much more a firm exposed to Germany tends to do more automation patents in a given year relative to 2005 .

Figure 5.a reports the results. The value of -2.3 in 2010 means that on average a firm with a German weight of 0.1 (the mean value is 0.106 ) engaged in a $20 \%$ smaller increase in automation innovations between 2005 and 2010 than a firm with no German exposure. From 2000 till 2004, firms highly exposed to Germany increased their propensity to introduce automation innovations, such a pre-trend is not surprising in this context since firms exposed to Germany are by definition exposed to different shocks than others. This trend reversed between 2006 and 2009 and resumed from 2010. This is consistent with the Hartz reform increasing labor supply from 2003 onwards and therefore decreasing the incentive to introduce automation innovations from 2005. 2008 marks the beginning 


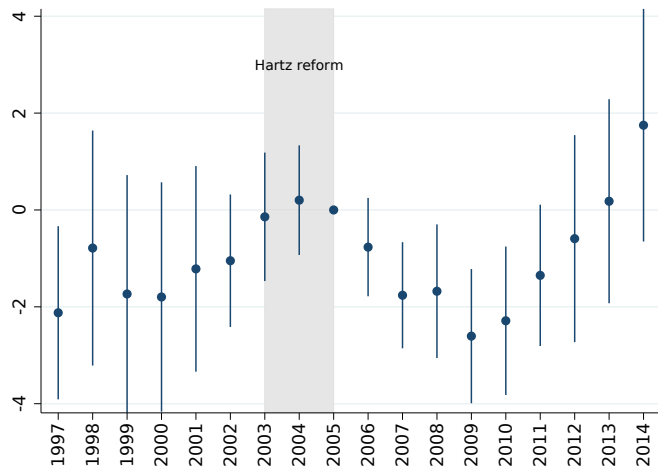

(a) Effect of German exposure on automation innovations

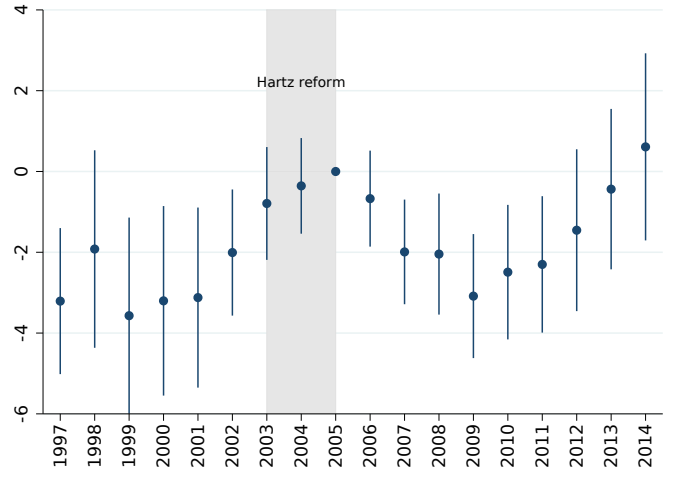

(b) Effect of German exposure on automation innovations relative to other machinery innovations.

Figure 5: Effect of German exposure on automation innovations. Panel (a) reports coefficients on the interaction between the German weight and a set of year fixed effects in a Poisson regression of auto95 innovations controlling for a full set of fixed effects and firm innovation stocks with 2153 firms. Panel (b) reports coefficients on the triple interaction between the German weight, a dummy for auto95 innovations and a set of year fixed effects in a Poisson regression of auto95 and other machinery innovations controlling for a full set of fixed effects, firm innovation stocks and the interaction between the German weight and a set of year fixed effects with 6452 firms.

of the Great Recession which had a lower impact on German labor markets than in other countries potentially increasing the relative incentive to undertake automation innovations (with an effect 2 years later).

The previous figure clearly shows that the behavior of firms highly exposed to Germany differs over time from that of other firms. To show that the trends above are specific to automation innovations, we run the following regression:

$$
P A T_{k, i, t}=\exp \left(\begin{array}{c}
\beta_{D E} \cdot \delta_{t} \omega_{i, D E}+\beta_{D E}^{a u t} \cdot \delta_{t} \omega_{i, D E} 1_{k=a u t} \\
+\beta_{K a} \cdot \delta_{k} \ln K_{A u t, i, t-2}+\beta_{K o} \cdot \delta_{k} \ln K_{\text {other }, i, t-2}+\delta_{k, i}+\delta_{k, c, t}
\end{array}\right)+\epsilon_{k, i, t} .
$$

$k$ denotes the type of an innovation which is either auto95 or another machinery innovation, $\delta_{k, i}$ represents a full set of innovation type firm fixed effects, $\delta_{k, c, t}$ innovation type country year fixed effects and $1_{k=a u t}$ is a dummy for an auto95 innovation. Standard errors are clustered at the firm level. $\beta_{D E}^{\text {aut }}$ is the vector of coefficients of interests. For each year, they measure how much exposure to Germany increases the relative propensity to introduce automation innovations instead of other forms of machinery innovations compared to 2005. Figure 5.b reports the results: the pattern is, if anything, more 
Table 13: Innovation and exposure to Germany

\begin{tabular}{|c|c|c|c|c|c|c|}
\hline \multirow[t]{2}{*}{ Dependent variables } & \multicolumn{4}{|c|}{ Auto 95 and other + low auto } & \multirow{2}{*}{$\begin{array}{c}\begin{array}{c}\text { Auto95 and } \\
\text { low auto }\end{array} \\
(5)\end{array}$} & \multirow{2}{*}{$\begin{array}{c}\begin{array}{l}\text { Auto95, low auto } \\
\text { and other mach. }\end{array} \\
(6)\end{array}$} \\
\hline & (1) & $(2)$ & $(3)$ & (4) & & \\
\hline time trend*dummy auto95*German exposure & $\begin{array}{c}0.6035^{* * *} \\
(0.2294)\end{array}$ & $\begin{array}{c}0.6037^{* * * *} \\
(0.2089)\end{array}$ & $\begin{array}{c}0.7453^{* *} \\
(0.3703)\end{array}$ & $\begin{array}{c}0.0935^{* * *} \\
(0.0345)\end{array}$ & $\begin{array}{c}0.6331^{* * *} \\
(0.2266)\end{array}$ & $\begin{array}{c}0.6034^{* * *} \\
(0.2137)\end{array}$ \\
\hline time trend*dummy auto95* post_ $2003^{*}$ German exposure & $\begin{array}{c}-1.2012^{* * *} \\
(0.3965)\end{array}$ & $\begin{array}{c}-1.2039^{* * * *} \\
(0.3776)\end{array}$ & $\begin{array}{c}-1.2942^{* * *} \\
(0.4775)\end{array}$ & $\begin{array}{c}-0.1791^{* * *} \\
(0.0727)\end{array}$ & $\begin{array}{c}-1.2580^{* * *} \\
(0.4075)\end{array}$ & $\begin{array}{c}-1.1875^{* * * *} \\
(0.3840)\end{array}$ \\
\hline dummy auto $95^{*}$ post_2003*German exposure & & & $\begin{array}{c}-0.6836 \\
(1.0374)\end{array}$ & & & \\
\hline time trend*dummy low auto*German exposure & & & & & & $\begin{array}{l}-0.0260 \\
(0.1236)\end{array}$ \\
\hline time trend*dummy low auto*post_2003*German exposure & & & & & & $\begin{array}{c}0.0647 \\
(0.1768)\end{array}$ \\
\hline year dummy*German exposure & $\mathrm{Y}$ & $\mathrm{Y}$ & $\mathrm{Y}$ & $\mathrm{Y}$ & $\mathrm{Y}$ & $\mathrm{Y}$ \\
\hline firm innovation stocks $*$ innovation types & $\mathrm{N}$ & $\mathrm{Y}$ & $\mathrm{Y}$ & $\mathrm{Y}$ & $\mathrm{Y}$ & $\mathrm{Y}$ \\
\hline firm *innovation types fixed effects & $\mathrm{Y}$ & $\mathrm{Y}$ & $\mathrm{Y}$ & $\mathrm{Y}$ & $\mathrm{Y}$ & $\mathrm{Y}$ \\
\hline country $*$ year $*$ innovation types fixed effects & $\mathrm{Y}$ & $\mathrm{Y}$ & $\mathrm{Y}$ & $\mathrm{Y}$ & $\mathrm{Y}$ & $\mathrm{Y}$ \\
\hline Observations & 77456 & 77456 & 77456 & 77456 & 62173 & 107284 \\
\hline Firms & 5427 & 5427 & 5427 & 5427 & 4350 & 5427 \\
\hline
\end{tabular}

Note: Marginal effects; Standard errors in parentheses. Estimation is by conditional Poisson regressions fixed-effects (HHG). All regressions control for year dummies times the measure of German exposure, innovation stocks (and dummies for no stocks) times the innovation types, firm innovation types fixed effects and country year innovation types fixed effects. The innovation stocks are lagged by two periods. Innovation types are auto95 and all other machinery innovations (low auto and other machinery together) in columns (1) to (4), auto95 and low auto in column (5), and auto95, low auto and other machinery in column (6). German exposure is measured by the German weights in all regressions except for column (4) where it is replaced by a dummy signaling that the firm is in the top quartile of Germany exposed firms. Standard errors are clustered at the firm-level. ${ }^{*} \mathrm{p}<0.1 ;{ }^{* *} \mathrm{p}<0.05 ;{ }^{* * *} \mathrm{p}<0.01$ ${ }^{*} \mathrm{p}<0.1 ; * * \mathrm{p}<0.05 ;{ }^{* * *} \mathrm{p}<0.01$

pronounced than in Figure 5.a.

To formally test that the Hartz reform created a trend break in the relative propensity of firms highly exposed to Germany to introduce automation innovation relative to other machinery innovation, we replace the full set of year fixed-effects $\delta_{t}$ in $\beta_{D E}^{a u t} \cdot \delta_{t} \omega_{i, D E} 1_{k=a u t}$ in equation (5) with a time trend $t-2005$ and a time trend interacted with a post 2005 dummy $(t-2005)_{t>2005}$. We focus on the years 2000-2010 to have a panel centered on 2005 and avoid the Great Recession. This exercise is akin to a triple diff except that our treatment is distributed continuously (depending on the exposure of each firm to Germany). Table 13 reports the result. Column (2) corresponds exactly to (5): there is a significant time trend in the effect of German exposure on the relative propensity to carry automation innovation between 2000 and 2005, but this trend sharply reverses in the following five years. Column (1) omits the controls for the stock variables. Columns (3) tests whether there is also a shift in level and does not find one. Column (4) replaces the German weight by a dummy indicating that the firm is in the top quartile of German exposure. Column (5) uses the low-automation innovations of section 5.3 instead of all other machinery innovations. Finally, column (6) considers three types of innovations by separating non-auto95 machinery innovations into the low-automation innovations of the previous columns and the rest. In all cases, the trend break remains with a consistent 
magnitude (since the $75^{\text {th }}$ percentile of German weight is 0.16). Overall, this exercise shows that, in line with our theory, the Hartz reforms reduced automation innovation of foreign firms highly exposed to Germany, both in absolute terms and relative to other types of machinery innovation.

\section{Conclusion}

In this paper, we identify automation patents and thereby provide a new measure of automation. Our measure is available at a highly disaggregated level and covers a broad range of technologies. Further, it predicts a decline in routine tasks across US sectors. We then use our classification to analyze the effect of labor market conditions on automation innovations in machinery. We first use global data and find that automation innovations are very responsive to changes in low-skill wages with elasticities between 2 and 5 . We proceed to show that the German Hartz reforms led to a relative decrease in automation innovations by foreign firms with a high exposure to Germany. Though using different variations in the data, both exercises emphasize that automation innovations are much more responsive to changes in labor market conditions than other innovations.

These results suggest that policies which increase labor costs for low-skill workers will lead to an increase in innovations which save on them. Therefore, with endogenous technological change, such policies are likely to be less costly for the economy in terms of overall welfare, but also to introduce additional negative effects for low-skill workers. Our paper provides a building block toward estimating by how much a policy-induced increase in low-skill wages would be undone in a couple of years through innovation.

Future research could also adapt our classification method to automation patents beyond machinery. This would allow for an analysis of automation in the service industry or automation of high-skill tasks through Artificial Intelligence.

\section{References}

Acemoglu, D. and Linn, J. (2004). Market size in innovation: Theory and evidence from the pharmaceutical industry. Quarterly Journal of Economics, 119(3):1049-1090.

Acemoglu, D. and Restrepo, P. (2018a). The race between machine and man: Implications of technology for growth, factor shares and employment. American Economic Review, 108(6):1488-1542. 
Acemoglu, D. and Restrepo, P. (2018b). Demographics and automation. NBER Working Paper 24421.

Acemoglu, D. and Restrepo, P. (2020). Robots and jobs: Evidence from US labor markets. Journal of Political Economy, 128(6):2188-2244.

Adão, R., Kolesár, M., and Morales, E. (2019). Shift-share designs: Theory and inference. The Quarterly Journal of Economics, 134(4):1949-2010.

Aghion, P., Bénabou, R., Martin, R., and Roulet, A. (2020). Environmental preferences and technological choices: Is market competition clean or dirty? NBER wp 26921.

Aghion, P., Dechezleprêtre, A., Hémous, D., Martin, R., and Van Reenen, J. (2016). Carbon taxes, path dependency, and directed technical change: Evidence from the auto industry. Journal of Political Economy, 214(1):1-51.

Andersson, D., Karadja, M., and Prawitz, E. (2020). Mass migration and technological change.

Aschhoff, B., Crass, D., Cremers, K., Grimpe, C., Rammer, C., Brandes, F., DiazLopez, F., Klein Woolthuis, R., Mayer, M., and Montalvo, C. (2010). European competitiveness in key enabling technologies. Technical report, Centre for European Economic Research (ZEW) and TNO.

Autor, D. and Dorn, D. (2013). The Growth of Low-Skill Service Jobs and the Polarization of the U.S. Labor Market. American Economic Review, 103(5):1553-1597.

Autor, D., Dorn, D., Hanson, G., Pisano, G., and Shu, P. (2020). Foreign competition and domestic innovation: Evidence from u.s. patents. American Economic Review: Insights, 2(3):357-374.

Autor, D., Levy, F., and Murnane, R. (2003). The Skill Content of Recent Technological Change: An Empirical Exploration. The Quarterly Journal of Economics, 118(4):1279-1333.

Bena, J. and Simintzi, E. (2019). Machines could not compete with Chinese labor: Evidence from U.S. firms' innovation. mimeo.

Bessen, J., Goos, M., Salomons, A., and van der Berge, W. (2019). Automatic reaction - what happens to workers at firms that automate?

Bessen, J. and Hunt, R. (2007). An empirical look at software patents. Journal of Economics and Management Strategy, 16(1):157-189.

Blundell, R., Griffith, R., and Van Reenen, J. (1999). Market share, market value and innovation in a panel of British manufacturing firms. The Review of Economic Studies, $66(3): 529-554$. 
Borusyak, K., Hull, P., and Jaravel, X. (2018). Quasi-experimental shift-share research designs.

Cameron, A. C., Gelbach, J., and Miller, D. (2008). Boostrap-based improvements for inference with clustered errors. The Review of Economics and Statistics, 90(3):414427.

Clemens, M., Lewis, E., and Postel, H. (2018). Immigration restrictions as active labor market policy: Evidence from the Mexican bracero exclusion. American Economic Review, 108(6):1468-87.

Coelli, F., Moxnes, A., and Ulltveit-Moe, K. (2020). Better, faster, stronger: Global innovation and trade liberalization. The Review of Economics and Statistics.

Correia, S., Guimarães, P., and Zylkin, T. (2020). Fast poisson estimation with highdimensional fixed effects. The Stata Journal, 20(1):95-115.

Danzer, A., Feuerbaum, C., and Gaessler, F. (2020). Labor supply and automation innovation. BGPE DIscussion Paper No 198.

de Rassenfosse, G., Dernis, H., Guellec, D., Picci, L., and van Pottelsberghe de la Potterie, B. (2013). The worldwide count of priority patents: A new indicator of inventive activity. Research Policy, 42(3):720-737.

Dechezleprêtre, A., Glachant, M., Hascic, I., Johnstone, N., and Ménière, Y. (2011). Invention and transfer of climate change-mitigation technologies: a global analysis. Review of Environmental Economics and Policy, 5:109-130.

Dechezleprêtre, A., Ménière, Y., and Mohnen, M. (2017). International patent families: from application strategies to statistical indicators. Scientometrics, 111(2):793-828.

Doms, M., Dunne, T., and Troske, K. (1997). Workers, Wages, and Technology. Quarterly Journal of Economics, 112(1):253-290.

Eaton, J. and Kortum, S. (1996). Trade in ideas: patenting and productivity in the OECD. Journal of International Economics, 40:251-278.

Eaton, J., Kortum, S., and Kramarz, F. (2011). An anatomy of international trade: evidence from French firms. Econometrica, 79(5):1453-1498.

Gaggl, P. and Wright, G. (2017). A short-run view of what computers do: Evidence from a UK tax incentive. American Economic Journal: Applied Economics, 9(3):262-94.

Goldsmith-Pinkham, P., Sorkin, I., and Swift, H. (2020). Bartik instruments: What, when, why, and how. The American Economic Review, 110(8):2586-2624.

Graetz, G. and Michaels, G. (2018). Robots at work. Review of Economics and Statistics, $100(5): 753-768$. 
Hausman, J., Hall, B., and Griliches, Z. (1984). Econometric models for count data with an application to the patents-R\&D relationship. Econometrica, 52(4):909-938.

Hémous, D. and Olsen, M. (forthcoming). The rise of the machines: Automation, horizontal innovation and income inequality. American Economic Journal: Macroeconomics.

Hornbeck, R. and Naidu, S. (2014). When the levee breaks: Black migration and economic development in the American South. American Economic Review, 104(3):963990.

Krause, M. and Uhlig, H. (2012). Transitions in the German labor market: Structure and crisis. Journal of Monetary Economics, 59(1):64-79.

Krusell, P., Ohanian, L., Ríos-Rull, J.-V., and Violante, G. (2000). Capital-Skill Complementarity and Inequality: A Macroeconomic Analysis. Econometrica, 68(5):10291053.

Lewis, E. (2011). Immigration, skill mix and capital skill complementarity. Quarterly Journal of Economics, 126 (2):1029-1069.

Lordan, G. and Neumark, D. (2018). People versus machines: The impact of minimum wages on automatable jobs. Labour Economics, 52(40-53).

Mann, K. and Puettmann, L. (2018). Benign effects of automation: New evidence from patent texts.

Noailly, J. and Smeets, R. (2015). Directing technical change from fossil-fuel to renewable energy innovation: An application using firm-level patent data. Journal of Environmental Economics and Management, 72:15-37.

Popp, D. (2002). Induced innovation and energy prices. The American Economic Review, $92(1): 160-180$.

Timmer, M., Dietzenbacher, E., Los, B., Stehrer, R., and de Vries, G. J. (2015). An illustrated user guide to the world input-output database: the case of global automotive production. Review of International Economics, 23(3).

Timmer, M., Erumban, A. A., Los, B., Stehrer, R., and de Vries, G. (2014). Slicing up global value chains. Journal of Economic Perspectives, 28(2):99-118.

Webb, M. (2020). The impact of artificial intelligence on labor market.

Zeira, J. (1998). Workers, Machines, and Economic Growth. Quarterly Journal of Economics, 113(4):1091-1117. 


\section{A Online Appendix}

\section{A.1 Additional Figures and Tables}

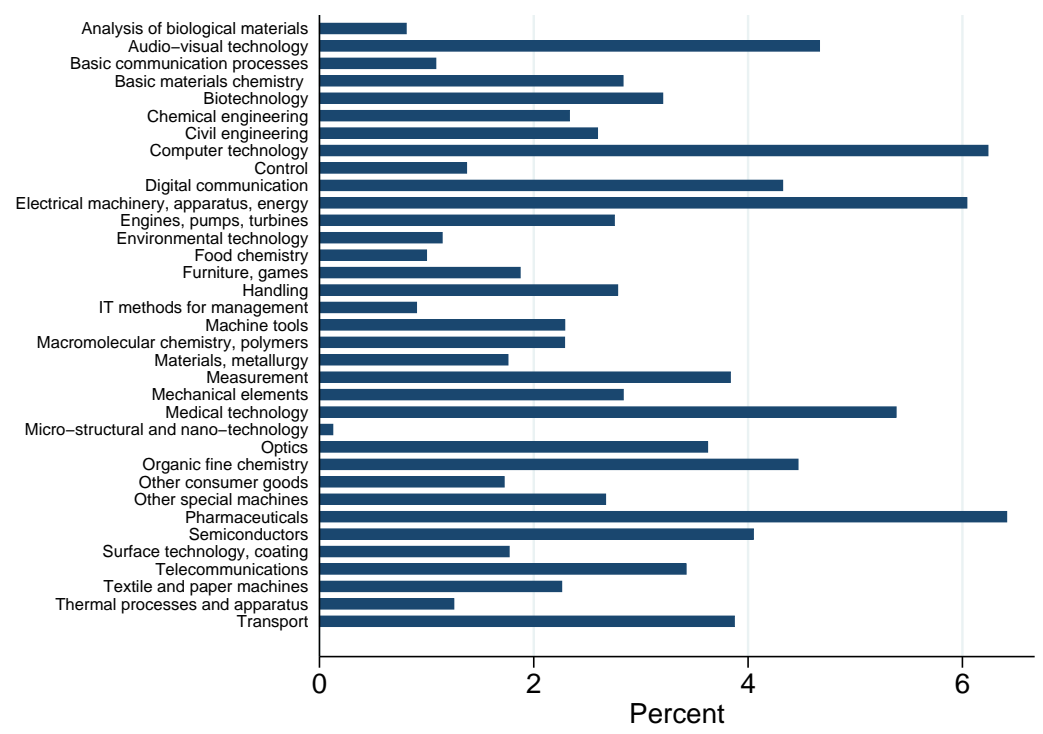

Figure A.1: Share of biadic patent applications in the different technical fields in 1997-2011

(19)

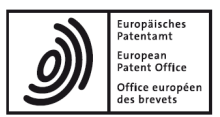

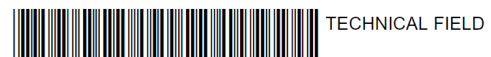

(11)
The present invention relates to a storage cabinet that stores contents (items) such as products and goods.

BACKGROUND ART

[0002] A storage cabinet is known that manages contents (items) by using radio frequency identification (RFID) technology. The patent literature 1 for example describes that scanning is performed in a cabinet for monitoring a product including a RF tag for the purpose of searching for an expired product or a product that have been manufactured in a recalled lot.

(86) International application number: PCT/JP2016/063339

(87) International publication number: WO 2016/175280 (03.11.2016 Gazette 2016/44)

(84) Designated Contracting States: AL AT BE BG CH CY 1 (72) Inventors: GR HR HUE GR HR HU IE IS IT LI LT LU LV MC MK MT NL NO PL PT RO RS SE SI SK SM TR Designated Extension States: BA ME

Designated Validation States: MA MD

(30) Priority: 28.04.2015 JP 2015091125

(71) Applicant: Sato Holdings Kabushiki Kaisha Tokyo 153-0064 (JP)

\section{- UNO, Yoshiaki} Singapore 408723 (SG)

- KASDANI, Yusita Singapore 408723 (SG)

(74) Representative: Grünecker Patent- und Rechtsanwälte PartG mbB

Leopoldstraße 4 80802 München (DE)
[0004] The conventional storage cabinet such as one described above may be able to perform scanning an item such as a product in the cabinet by using RFID technology; however, it is necessary for an operator to visually check an expired product or a product that have been manufactured in a recalled lot and remove them from the cabinet. Thus, there is a drawback in the conventional storage storage cabinet that, in a case in which many products are stored in the storage cabinet for example, the operator cannot immediately recognize whether all products to be removed have been actually retrieved from the storage cabinet.

[0005] Particularly, in a case in which the storage cabinet is not connected to a network, the operator cannot check whether all products to be removed have been actually retrieved from the storage cabinet. [0006] In view of the above, one of the aspects of the present invention is to provide a storage cabinet from which one can surely retrieve a desired item.

(54) STORAGE CABINET

Figure A.2: Example of an automation patent without keywords 


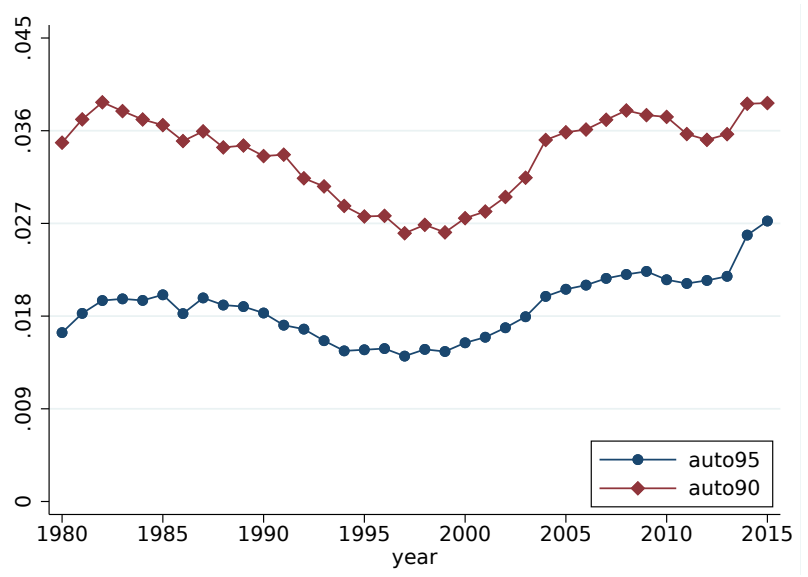

(a) Share of automation patents in machinery out of total patents according to the auto90 and auto95 definitions.

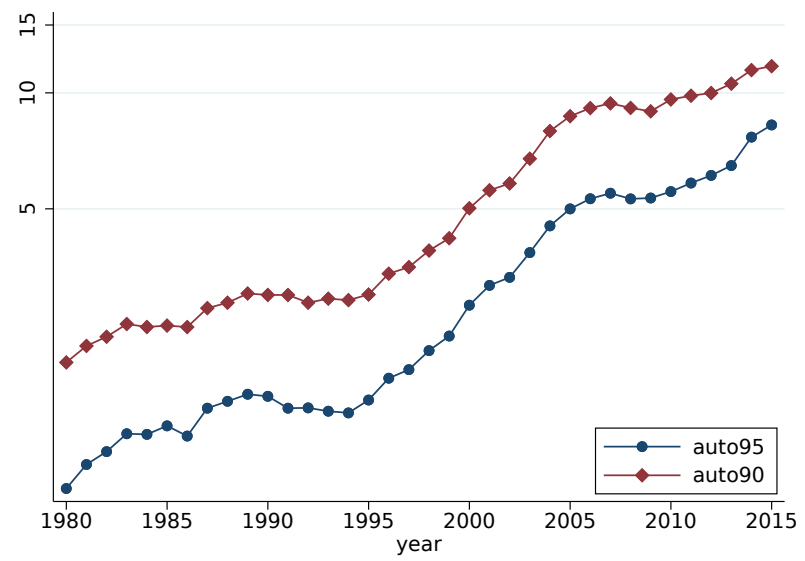

(b) Number of automation patents worldwide according to the auto90 and auto95 definitions

Figure A.3: Trends in automation (for biadic applications)

Table A.1: Summary statistics on the prevalence of keywords

\begin{tabular}{|c|c|c|c|c|c|c|c|c|c|c|c|c|c|c|c|}
\hline \multirow[b]{2}{*}{ Share } & \multicolumn{5}{|c|}{ IPC/CPC 6 digit } & \multicolumn{5}{|c|}{ IPC4 + (G05 or G06) } & \multicolumn{5}{|c|}{ IPC4 pairs } \\
\hline & all & robot & automat* & $\mathrm{CNC}$ & labor & all & robot & automat* & $\mathrm{CNC}$ & labor & all & robot & automat* & $\mathrm{CNC}$ & labor \\
\hline Mean & 20.9 & 4.3 & 11.2 & 2.4 & 5.9 & 53.2 & 15.4 & 32.4 & 11.2 & 9.5 & 18.5 & 4.5 & 8.8 & 1.8 & 5.4 \\
\hline S. d. & 14.4 & 8.4 & 9.5 & 5.8 & 3.7 & 19.3 & 17.7 & 11 & 16.5 & 3.8 & 16.3 & 10 & 9.9 & 4.7 & 3.8 \\
\hline p25 & 10.5 & 0.8 & 4.2 & 0 & 3.3 & 40 & 6.7 & 26.6 & 0.8 & 2.6 & 7.7 & 0.6 & 2.5 & 0 & 2.6 \\
\hline p50 & 18 & 2 & 8.7 & 0.4 & 5.3 & 54.3 & 10 & 31.9 & 3 & 4.6 & 13.6 & 1.8 & 5.2 & 0.4 & 4.6 \\
\hline p75 & 26.6 & 4.5 & 15.3 & 1.8 & 7.7 & 63.8 & 16 & 40.3 & 15.5 & 7.3 & 23 & 4.2 & 10.7 & 1.4 & 7.3 \\
\hline p90 & 38.7 & 9.1 & 24.3 & 6.1 & 10.4 & 77.9 & 36.4 & 43.3 & 38.2 & 10.4 & 36.8 & 8.9 & 21.7 & 4.4 & 10.4 \\
\hline p95 & 47.7 & 13.7 & 29.4 & 12.7 & 12.7 & 85.6 & 44.3 & 45.2 & 55.3 & 12.3 & 51.8 & 14.5 & 31 & 7.7 & 12.3 \\
\hline p99 & 75 & 35.8 & 43.8 & 33.1 & 17.9 & 90.1 & 82.9 & 59.9 & 56.6 & 17.9 & 84.5 & 60 & 45.3 & 23.1 & 17.9 \\
\hline
\end{tabular}

Note: This table computes summary statistics on the share of patents with any automation keywords, robot keywords, automat* keywords, CNC keywords or labor keywords for each type of technological categories (6 digit codes, pairs of 4 digit codes and combinations of ipc4 codes with G05 or G06) within machinery with at least 100 patents.

Table A.2: Industry of innovators

\begin{tabular}{|c|c|c|c|}
\hline & Industry & Share auto95 $(\%)$ & Share firms (\%) \\
\hline 20 & Manufacture of chemicals and chemical products & 2.18 & 3.45 \\
\hline 25 & Manufacture of fabricated metal products, except machinery and equipment & 1.18 & 4.39 \\
\hline 26 & Manufacture of computer, electronic and optical products & 22.83 & 7.42 \\
\hline 27 & Manufacture of electrical equipment & 9.19 & 2.76 \\
\hline 28 & Manufacture of machinery and equipment n.e.c. & 24.52 & 20.97 \\
\hline 29 & Manufacture of motor vehicles, trailers and semi-trailers & 5.31 & 3.48 \\
\hline 30 & Manufacture of other transport equipment & 4.5 & 1.2 \\
\hline 46 & Wholesale trade, except of motor vehicles and motorcycles & 1.34 & 3.3 \\
\hline 64 & Financial service activities, except insurance and pension funding & 1.75 & 0.96 \\
\hline \multirow[t]{3}{*}{72} & Scientific research and development & 2.04 & 2.37 \\
\hline & Other industries & 13.23 & 27.15 \\
\hline & No information on industry & 11.94 & 22.5 \\
\hline
\end{tabular}

Notes: The table reports the industry of manufacturing of firms included in our baseline regression with industry-year fixed effects at the NACEv2 division level and the share of biadic auto95 families for each industry. Industries representing less than $1 \%$ of patents are summed up in the "Other industries" category. 
Table A.3: Correlation matrix

\begin{tabular}{|c|c|c|c|c|c|c|}
\hline & Low-skill wage & Middle-skill wage & High-skill wage & GDP gap & GDP per capita & Labor productivity \\
\hline Low-skill wage & 1.00 & & & & & \\
\hline Middle-skill wage & 0.94 & 1.00 & & & & \\
\hline High-skill wage & 0.60 & 0.75 & 1.00 & & & \\
\hline GDP gap & -0.06 & -0.05 & -0.03 & 1.00 & & \\
\hline GDP per capita & 0.70 & 0.80 & 0.73 & 0.11 & 1.00 & \\
\hline Labor productivity & 0.67 & 0.73 & 0.77 & 0.04 & 0.66 & 1.00 \\
\hline
\end{tabular}

Note: Correlation of residuals for the auto95 sample controlling for firm and year-industry fixed effects.

Table A.4: Top 10 auto95 innovators in our sample

\begin{tabular}{lc}
\hline \hline Company & $\begin{array}{c}\text { Number of biadic auto95 } \\
\text { patents in 1997-2011 }\end{array}$ \\
\hline Siemens Aktiengesellschaft & 1738 \\
Honda Motor Co., Ltd. & 810 \\
Fanuc Co. & 777 \\
Samsung Electronics Co., Ltd. & 706 \\
Robert Bosch GmbH & 655 \\
Mitsubishi Electric Co. & 652 \\
Tokyo Electron, Ltd. & 578 \\
Murata Machinery, Ltd. & 501 \\
Kabushiki Kaisha Toshiba & 473 \\
General Electric Company & 464 \\
\hline \hline
\end{tabular}

Table A.5: Baseline regressions for auto95 with country-level clustering

\begin{tabular}{lccccccccc}
\hline \hline Dependent variable & \multicolumn{9}{c}{ Auto95 } \\
\cline { 2 - 10 } & $(1)$ & $(2)$ & $(3)$ & $(4)$ & $(5)$ & $(6)$ & $(7)$ & $(8)$ & $(9)$ \\
\hline Low-skill wage & $2.21^{* * *}$ & $2.83^{* * *}$ & $1.80^{* * *}$ & $2.46^{* * *}$ & $2.32^{* * *}$ & $2.54^{* * *}$ & $2.90^{* * *}$ & $2.67^{* * *}$ & $3.59^{* * *}$ \\
& $(0.54)$ & $(0.73)$ & $(0.63)$ & $(0.61)$ & $(0.77)$ & $(0.70)$ & $(0.65)$ & $(0.74)$ & $(1.04)$ \\
& {$[0.000]$} & {$[0.000]$} & {$[0.004]$} & {$[0.000]$} & {$[0.002]$} & {$[0.000]$} & {$[0.000]$} & {$[0.000]$} & {$[0.001]$} \\
& $\{0.000\}$ & $\{0.002\}$ & $\{0.030\}$ & $\{0.031\}$ & $\{0.038\}$ & $\{0.094\}$ & $\{0.008\}$ & $\{0.019\}$ & $\{0.015\}$ \\
\hline High-skill wage & & Yes & Yes & Yes & Yes & Yes & Yes & Yes & Yes \\
GDP gap & & & & Yes & Yes & Yes & Yes & Yes & Yes \\
Labor productivity & & & & & Yes & & & Yes & Yes \\
GDP per capita & & & & & & Yes & & & Yes \\
Stocks & & & Yes & Yes & Yes & Yes & Yes & Yes \\
Spillovers & & & & & & Yes & Yes & Yes \\
Fixed effects & $\mathrm{F}+\mathrm{Y}$ & $\mathrm{F}+\mathrm{Y}$ & $\mathrm{F}+\mathrm{Y}$ & $\mathrm{F}+\mathrm{IY}$ & $\mathrm{F}+\mathrm{IY}$ & $\mathrm{F}+\mathrm{IY}$ & $\mathrm{F}+\mathrm{IY}$ & $\mathrm{F}+\mathrm{IY}$ & $\mathrm{F}+\mathrm{IY}$ \\
\hline Observations & 50115 & 50115 & 50115 & 49174 & 49174 & 49174 & 49174 & 49174 & 49174 \\
Firms & 3341 & 3341 & 3341 & 3329 & 3329 & 3329 & 3329 & 3329 & 3329 \\
\hline \hline
\end{tabular}

Note: This table reproduces the baseline table but clusters standard errors at the country-level. [ ] brackets correspond to the p-value associated with estimated standard errors, \{\} brackets correspond to the p-values associated with the clustered standard errors following Cameron et. (2008). See text for details. ${ }^{*} p<0.1 ;{ }^{* *} p<0.05 ;{ }^{* * *}$ $p<0.01$ 
Table A.6: Auto90 innovations

\begin{tabular}{|c|c|c|c|c|c|c|c|c|c|}
\hline \multirow{3}{*}{ Dependent variable } & \multicolumn{9}{|c|}{ Auto90 } \\
\hline & \multicolumn{6}{|c|}{ Domestic+Foreign } & \multicolumn{3}{|c|}{ Foreign } \\
\hline & (1) & $(2)$ & (3) & (4) & (5) & $(6)$ & $(7)$ & (8) & (9) \\
\hline Low-skill wage & $\begin{array}{c}2.19^{* * *} \\
(0.65)\end{array}$ & $\begin{array}{c}1.95^{* * *} \\
(0.67)\end{array}$ & $\begin{array}{c}3.10^{* * *} \\
(0.77)\end{array}$ & $\begin{array}{l}1.57^{*} \\
(0.81)\end{array}$ & $\begin{array}{l}1.57^{*} \\
(0.87)\end{array}$ & $\begin{array}{l}2.61^{* *} \\
(1.03)\end{array}$ & $\begin{array}{c}3.02^{* * *} \\
(1.12)\end{array}$ & $\begin{array}{c}3.49^{* * *} \\
(1.30)\end{array}$ & $\begin{array}{l}3.46^{* *} \\
(1.42)\end{array}$ \\
\hline High-skill wage & $\begin{array}{c}-1.85^{* * *} \\
(0.59)\end{array}$ & $\begin{array}{c}-2.27^{* * *} \\
(0.65)\end{array}$ & $\begin{array}{l}-0.85 \\
(0.65)\end{array}$ & $\begin{array}{c}-1.78^{* *} \\
(0.80)\end{array}$ & $\begin{array}{l}-1.76^{*} \\
(0.91)\end{array}$ & $\begin{array}{l}-1.09 \\
(0.85)\end{array}$ & $\begin{array}{c}-3.50^{* * *} \\
(1.14)\end{array}$ & $\begin{array}{c}-2.80^{* *} \\
(1.30)\end{array}$ & $\begin{array}{c}-3.24^{* * *} \\
(1.22)\end{array}$ \\
\hline GDP gap & $\begin{array}{l}-3.85^{*} \\
(2.10)\end{array}$ & $\begin{array}{c}-4.41^{* *} \\
(2.14)\end{array}$ & $\begin{array}{l}-1.53 \\
(2.25)\end{array}$ & $\begin{array}{c}4.47 \\
(5.20)\end{array}$ & $\begin{array}{c}4.49 \\
(5.29)\end{array}$ & $\begin{array}{c}6.23 \\
(5.37)\end{array}$ & $\begin{array}{l}-0.95 \\
(3.25)\end{array}$ & $\begin{array}{c}0.06 \\
(3.52)\end{array}$ & $\begin{array}{l}-0.09 \\
(3.66)\end{array}$ \\
\hline Labor productivity & & $\begin{array}{c}0.95 \\
(0.73)\end{array}$ & & & $\begin{array}{l}-0.03 \\
(1.29)\end{array}$ & & & $\begin{array}{l}-1.11 \\
(1.32)\end{array}$ & \\
\hline GDP per capita & & & $\begin{array}{c}-2.60^{* *} \\
(1.03)\end{array}$ & & & $\begin{array}{l}-2.55^{*} \\
(1.45)\end{array}$ & & & $\begin{array}{l}-0.79 \\
(1.53)\end{array}$ \\
\hline Stocks / Spillovers & Yes & Yes & Yes & Yes & Yes & Yes & Yes & Yes & Yes \\
\hline Fixed effects & $\mathrm{F}+\mathrm{IY}$ & $\mathrm{F}+\mathrm{IY}$ & $\mathrm{F}+\mathrm{IY}$ & $\mathrm{F}+\mathrm{IY}+\mathrm{CY}$ & $\mathrm{F}+\mathrm{IY}+\mathrm{CY}$ & $\mathrm{F}+\mathrm{IY}+\mathrm{CY}$ & $\mathrm{F}+\mathrm{IY}+\mathrm{CY}$ & $\mathrm{F}+\mathrm{IY}+\mathrm{CY}$ & $\mathrm{F}+\mathrm{IY}+\mathrm{CY}$ \\
\hline Observations & 72721 & 72721 & 72721 & 72439 & 72439 & 72439 & 72439 & 72439 & 72439 \\
\hline Firms & 4890 & 4890 & 4890 & 4887 & 4887 & 4887 & 4887 & 4887 & 4887 \\
\hline
\end{tabular}

Note: Marginal effects; Standard errors in parentheses. The independent variables are lagged by two periods. Estimation is done by conditional Poisson fixed-effects regressions (HHG). Columns (1)-(3) include firm and industry-year fixed effects, while (4)-(9) include firm, industry-year, and country-year fixed effects. In Columns (7)-(9) the macroeconomic variables are the normalized foreign variables previously defined. Stock and spillover variables are calculated with respect to the dependent variable (auto90). Standard errors are clustered at the firm-level. ${ }^{*} p<0.1 ;{ }^{* *} p<0.05 ;{ }^{* *} p<0.01$

Table A.7: Wages weighted by inventor weights

\begin{tabular}{|c|c|c|c|c|c|c|c|c|c|}
\hline \multirow[t]{3}{*}{ Dependent variable } & \multicolumn{9}{|c|}{ Auto95 } \\
\hline & \multicolumn{6}{|c|}{ Domestic+Foreign } & \multicolumn{3}{|c|}{ Foreign } \\
\hline & (1) & (2) & (3) & (4) & (5) & (6) & (7) & (8) & (9) \\
\hline Low-skill wage & $\begin{array}{c}2.99^{* * *} \\
(0.87)\end{array}$ & $\begin{array}{c}2.39^{* * *} \\
(0.92)\end{array}$ & $\begin{array}{c}3.39^{* * *} \\
(1.08)\end{array}$ & $\begin{array}{l}2.15^{* *} \\
(1.03)\end{array}$ & $\begin{array}{l}2.30^{* *} \\
(1.17)\end{array}$ & $\begin{array}{c}3.44^{* * *} \\
(1.32)\end{array}$ & $\begin{array}{c}5.53^{* * *} \\
(1.63)\end{array}$ & $\begin{array}{c}6.39^{* * *} \\
(1.81)\end{array}$ & $\begin{array}{c}5.37^{* * *} \\
(2.08)\end{array}$ \\
\hline Low-skill wage (iw) & $\begin{array}{l}-0.22 \\
(0.44)\end{array}$ & $\begin{array}{c}0.12 \\
(0.45)\end{array}$ & $\begin{array}{c}0.10 \\
(0.47)\end{array}$ & $\begin{array}{l}-0.02 \\
(0.45)\end{array}$ & $\begin{array}{c}0.26 \\
(0.45)\end{array}$ & $\begin{array}{c}0.14 \\
(0.47)\end{array}$ & $\begin{array}{c}0.00 \\
(0.53)\end{array}$ & $\begin{array}{c}0.74 \\
(0.58)\end{array}$ & $\begin{array}{c}0.71 \\
(0.54)\end{array}$ \\
\hline High-skill wage & $\begin{array}{c}-2.59^{* * *} \\
(0.85)\end{array}$ & $\begin{array}{c}-3.45^{* * *} \\
(0.93)\end{array}$ & $\begin{array}{c}-2.04^{* *} \\
(0.87)\end{array}$ & $\begin{array}{c}-3.02^{* * *} \\
(1.02)\end{array}$ & $\begin{array}{c}-2.60^{* *} \\
(1.09)\end{array}$ & $\begin{array}{c}-2.15^{* *} \\
(1.08)\end{array}$ & $\begin{array}{c}-5.15^{* * *} \\
(1.58)\end{array}$ & $\begin{array}{c}-4.53^{* * *} \\
(1.65)\end{array}$ & $\begin{array}{c}-5.66^{* * *} \\
(1.67)\end{array}$ \\
\hline High-skill wage (iw) & $\begin{array}{c}0.41 \\
(0.39)\end{array}$ & $\begin{array}{l}0.90^{* *} \\
(0.43)\end{array}$ & $\begin{array}{c}0.58 \\
(0.40)\end{array}$ & $\begin{array}{c}0.18 \\
(0.37)\end{array}$ & $\begin{array}{c}0.60 \\
(0.41)\end{array}$ & $\begin{array}{c}0.24 \\
(0.39)\end{array}$ & $\begin{array}{l}-0.27 \\
(0.47)\end{array}$ & $\begin{array}{l}1.01^{*} \\
(0.52)\end{array}$ & $\begin{array}{c}0.21 \\
(0.51)\end{array}$ \\
\hline GDP gap & $\begin{array}{c}-8.38^{* *} \\
(3.67)\end{array}$ & $\begin{array}{c}-9.83^{* * *} \\
(3.66)\end{array}$ & $\begin{array}{l}-6.89^{*} \\
(3.85)\end{array}$ & $\begin{array}{c}1.83 \\
(6.02)\end{array}$ & $\begin{array}{c}1.69 \\
(5.97)\end{array}$ & $\begin{array}{c}4.16 \\
(6.28)\end{array}$ & $\begin{array}{l}-2.28 \\
(4.26)\end{array}$ & $\begin{array}{l}-1.22 \\
(4.27)\end{array}$ & $\begin{array}{l}-3.06 \\
(4.72)\end{array}$ \\
\hline GDP gap (iw) & $\begin{array}{c}3.25 \\
(2.51)\end{array}$ & $\begin{array}{c}3.89 \\
(2.41)\end{array}$ & $\begin{array}{c}3.52 \\
(2.64)\end{array}$ & $\begin{array}{c}1.94 \\
(2.68)\end{array}$ & $\begin{array}{c}2.43 \\
(2.49)\end{array}$ & $\begin{array}{c}2.05 \\
(2.83)\end{array}$ & $\begin{array}{c}2.50 \\
(2.29)\end{array}$ & $\begin{array}{l}3.35^{*} \\
(1.86)\end{array}$ & $\begin{array}{c}3.89 \\
(2.38)\end{array}$ \\
\hline Labor productivity & & $\begin{array}{l}2.10^{*} \\
(1.12)\end{array}$ & & & $\begin{array}{l}-0.91 \\
(1.75)\end{array}$ & & & $\begin{array}{l}-1.54 \\
(1.62)\end{array}$ & \\
\hline Labor productivity (iw) & & $\begin{array}{c}-1.14^{* *} \\
(0.54)\end{array}$ & & & $\begin{array}{l}-1.02^{*} \\
(0.54)\end{array}$ & & & $\begin{array}{c}-2.08^{* * * *} \\
(0.65)\end{array}$ & \\
\hline GDP per capita & & & $\begin{array}{l}-1.27 \\
(1.43)\end{array}$ & & & $\begin{array}{l}-3.16^{*} \\
(1.86)\end{array}$ & & & $\begin{array}{c}0.81 \\
(2.29)\end{array}$ \\
\hline GDP per capita (iw) & & & $\begin{array}{l}-0.66 \\
(0.59) \\
\end{array}$ & & & $\begin{array}{l}-0.29 \\
(0.63) \\
\end{array}$ & & & $\begin{array}{c}-1.41^{* *} \\
(0.61) \\
\end{array}$ \\
\hline Stock automation & Yes & Yes & Yes & Yes & Yes & Yes & Yes & Yes & Yes \\
\hline Stock other & Yes & Yes & Yes & Yes & Yes & Yes & Yes & Yes & Yes \\
\hline Spillovers & Yes & Yes & Yes & Yes & Yes & Yes & Yes & Yes & Yes \\
\hline Fixed effects & $\mathrm{F}+\mathrm{IY}$ & $\mathrm{F}+\mathrm{IY}$ & $\mathrm{F}+\mathrm{IY}$ & $\mathrm{F}+\mathrm{IY}+\mathrm{CY}$ & $\mathrm{F}+\mathrm{IY}+\mathrm{CY}$ & $\mathrm{F}+\mathrm{IY}+\mathrm{CY}$ & $\mathrm{F}+\mathrm{IY}+\mathrm{CY}$ & $\mathrm{F}+\mathrm{IY}+\mathrm{CY}$ & $\mathrm{F}+\mathrm{IY}+\mathrm{CY}$ \\
\hline Observations & 48376 & 48376 & 48376 & 47977 & 47977 & 47977 & 36234 & 36234 & 36234 \\
\hline Firms & 3274 & 3274 & 3274 & 3268 & 3268 & 3268 & 2480 & 2480 & 2480 \\
\hline
\end{tabular}


Table A.8: Predicting weights using subsequent wages

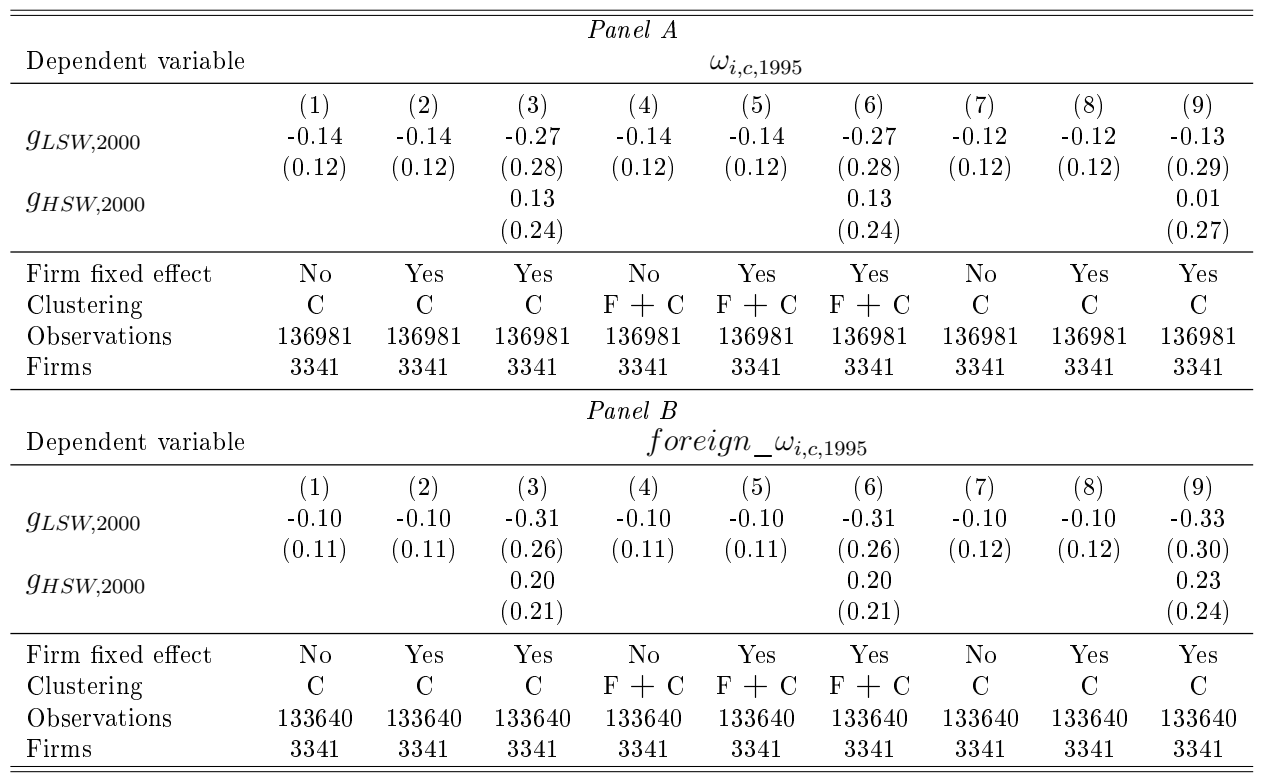

Note: OLS regressions of firm-level weights/foreign weights on country growth rates for low-skill and high-skill wages between 1995 and 2000. Columns (2), (3), (5), (6), (8) and (9) include firm fixed effects. Columns (7)(9) weigh observations by the number of auto95 patents between 1997 and 2011. Standard errors are clustered at the country-level for columns (1)-(3), (7)-(9)and clustered at both the country and firm levels for (4)-(6). * $p<0.1 ;{ }^{* *} p<0.05 ;{ }^{* * *} p<0.01$

Table A.9: Alternative weights

\begin{tabular}{|c|c|c|c|c|c|c|}
\hline \multirow[t]{3}{*}{ Dependent variable } & \multicolumn{6}{|c|}{ Auto95 } \\
\hline & 1970-1989 & $1985-1994$ & start 2000 & $G D P^{0}$ & $G D P^{1}$ & $\left(w_{L} \cdot L\right)^{0.35}$ \\
\hline & (1) & (2) & (3) & (4) & (5) & (6) \\
\hline \multicolumn{7}{|l|}{ Foreign: } \\
\hline Low-skill wage & $\begin{array}{c}5.07^{* * * *} \\
(1.88)\end{array}$ & $\begin{array}{c}4.98^{* * *} \\
(1.48)\end{array}$ & $\begin{array}{c}6.81^{* * * *} \\
(2.10)\end{array}$ & $\begin{array}{c}4.12^{* * * *} \\
(1.37)\end{array}$ & $\begin{array}{c}5.81^{* * *} \\
(1.68)\end{array}$ & $\begin{array}{c}5.11^{* * * *} \\
(1.50)\end{array}$ \\
\hline High-skill wage & $\begin{array}{c}-3.41^{* *} \\
(1.66)\end{array}$ & $\begin{array}{l}-1.51 \\
(1.52)\end{array}$ & $\begin{array}{l}-3.56^{*} \\
(2.03)\end{array}$ & $\begin{array}{c}-3.74^{* * *} \\
(1.32)\end{array}$ & $\begin{array}{c}-3.19^{* *} \\
(1.62)\end{array}$ & $\begin{array}{c}-3.40^{* *} \\
(1.32)\end{array}$ \\
\hline GDP gap & $\begin{array}{c}1.70 \\
(4.13)\end{array}$ & $\begin{array}{c}2.19 \\
(4.72)\end{array}$ & $\begin{array}{l}-0.47 \\
(3.78)\end{array}$ & $\begin{array}{l}-3.44 \\
(3.56)\end{array}$ & $\begin{array}{l}-1.83 \\
(3.85)\end{array}$ & $\begin{array}{l}-1.19 \\
(3.66)\end{array}$ \\
\hline Labor productivity & $\begin{array}{l}-2.03 \\
(1.75)\end{array}$ & $\begin{array}{c}-3.53^{* *} \\
(1.58)\end{array}$ & $\begin{array}{c}-4.38^{* *} \\
(1.74)\end{array}$ & $\begin{array}{l}-1.29 \\
(1.42)\end{array}$ & $\begin{array}{l}-1.59 \\
(1.57)\end{array}$ & $\begin{array}{l}-2.03 \\
(1.55)\end{array}$ \\
\hline Stocks / Spillovers & Yes & Yes & Yes & Yes & Yes & Yes \\
\hline Fixed effects & $\mathrm{F}+\mathrm{IY}+\mathrm{CY}$ & $\mathrm{F}+\mathrm{IY}+\mathrm{CY}$ & $\mathrm{F}+\mathrm{IY}+\mathrm{CY}$ & $\mathrm{F}+\mathrm{IY}+\mathrm{CY}$ & $\mathrm{F}+\mathrm{IY}+\mathrm{CY}$ & $\mathrm{F}+\mathrm{IY}+\mathrm{CY}$ \\
\hline Observations & 34710 & 44476 & 26577 & 48665 & 48802 & 48679 \\
\hline Firms & 2386 & 3031 & 2695 & 3323 & 3322 & 3325 \\
\hline
\end{tabular}

Note: Marginal effects; Standard errors in parentheses. The independent variables are lagged by two periods. Estimation is by conditional Poisson regressions fixed-effects (HHG). All regressions include firm, country-year and industry-year fixed effects. In column (1) firms' country weights for the macroeconomic variables are computed over the period 1970-1989; and over the period 1985-1994 for column (2). Columns (3) to (6) use the baseline pre-sample period of 1970-1994. Column (3) restricts the sample to the years 2000-2009. Column (4) does not adjust for GDP in the computation of the weights; Column (5) uses GDP instead of GDP 0.35 to adjust for country size and Column (6) replaces GDP with total low-skilled payment $w L$ in the baseline formula. In all columns the macroeconomic variables are the normalized foreign variables previously defined. Standard errors are clustered at the firm-level. ${ }^{*} p<0.1 ;{ }^{* *}$ $p<0.05 ;{ }^{* * *} p<0.01$ 
Table A.10: Excluding one country at the time

\begin{tabular}{lcccccccc}
\hline \hline Dependent Variable & \multicolumn{7}{c}{ Auto95 } \\
\hline Excl. country & None & US & DE & JP & GB & FR & IT \\
Average weight & & 0.21 & 0.20 & 0.17 & 0.09 & 0.09 & 0.03 & 0.03 \\
\hline & $(0)$ & $(1)$ & $(2)$ & $(3)$ & $(4)$ & $(5)$ & $(6)$ & $(7)$ \\
\hline Foreign: & & & & & & & \\
Low-skill wage & $5.08^{* * *}$ & $5.41^{* * *}$ & $3.60^{* * *}$ & $3.43^{* * *}$ & $4.78^{* * *}$ & $3.60^{* *}$ & $5.20^{* * *}$ & $4.84^{* * *}$ \\
& $(1.54)$ & $(1.68)$ & $(1.37)$ & $(1.33)$ & $(1.33)$ & $(1.48)$ & $(1.45)$ & $(1.51)$ \\
High-skill wage & $-2.95^{* *}$ & $-2.74^{*}$ & -1.72 & -1.57 & -0.82 & $-2.31^{*}$ & $-4.62^{* *}$ & $-2.51^{*}$ \\
& $(1.46)$ & $(1.46)$ & $(1.26)$ & $(1.29)$ & $(1.34)$ & $(1.33)$ & $(1.90)$ & $(1.48)$ \\
GDP gap & 1.29 & 0.73 & 2.62 & 1.59 & 1.99 & 0.97 & 1.19 & 1.05 \\
& $(4.84)$ & $(5.14)$ & $(5.58)$ & $(3.88)$ & $(4.85)$ & $(5.02)$ & $(5.13)$ & $(4.90)$ \\
Labor productivity & -2.15 & $-3.39^{* *}$ & -2.26 & -1.43 & $-3.24^{* *}$ & -1.49 & -0.73 & -2.35 \\
& $(1.58)$ & $(1.67)$ & $(1.39)$ & $(1.48)$ & $(1.58)$ & $(1.48)$ & $(1.63)$ & $(1.56)$ \\
\hline Stocks / Spillovers & Yes & Yes & Yes & Yes & Yes & Yes & Yes & Yes \\
Fixed effects & $\mathrm{F}+\mathrm{CY}+\mathrm{IY}$ & $\mathrm{F}+\mathrm{CY}+\mathrm{IY}$ & $\mathrm{F}+\mathrm{CY}+\mathrm{IY}$ & $\mathrm{F}+\mathrm{CY}+\mathrm{IY}$ & $\mathrm{F}+\mathrm{CY}+\mathrm{IY}$ & $\mathrm{F}+\mathrm{CY}+\mathrm{IY}$ & $\mathrm{F}+\mathrm{CY}+\mathrm{IY}$ & $\mathrm{F}+\mathrm{CY}+\mathrm{IY}$ \\
Control & & $\omega_{c} * Y$ & $\omega_{c} * Y$ & $\omega_{c} * Y$ & $\omega_{c} * Y$ & $\omega_{c} * Y$ & $\omega_{c} * Y$ & $\omega_{c} * Y$ \\
\hline Observations & 48773 & 47997 & 48319 & 48594 & 48391 & 48713 & 48638 & 48702 \\
Firms & 3324 & 3270 & 3291 & 3312 & 3299 & 3320 & 3315 \\
\hline \hline
\end{tabular}

Notes: Marginal effects; Standard errors in parentheses. The independent variables are lagged by two periods. Estimation is done by conditional Poisson fixed-effects regressions effects (HHG). All columns include firm, industry-year and country-year fixed effects. In Column (0), the macroeconomic variables are the normalized foreign variables previously defined. Columns (1) to (7) further exclude the country in the column header in addition to the domestic country when computing the normalized foreign macroeconomic variables. Columns (1) to (7) also control for the weight of the header-country times year dummies. The average weight is the average country weight for firms in the sample of Column (0). Standard errors are clustered at the firm-level. ${ }^{*} p<0.1$; ${ }^{* *} p<0.05$; $* * * p<0.01$

Table A.16: Addressing Nickell's bias

\begin{tabular}{|c|c|c|c|c|c|c|}
\hline \multirow[t]{3}{*}{$\overline{\text { Dependent variable }}$} & \multicolumn{6}{|c|}{ Auto95 } \\
\hline & \multicolumn{4}{|c|}{ Domestic+Foreign } & \multicolumn{2}{|c|}{ Foreign } \\
\hline & (1) & (2) & (3) & (4) & (5) & (6) \\
\hline Low-skill wage & $\begin{array}{c}2.64^{* * *} \\
(0.79)\end{array}$ & $\begin{array}{c}2.41^{* * * *} \\
(0.83)\end{array}$ & $\begin{array}{l}2.67^{* *} \\
(1.05)\end{array}$ & $\begin{array}{c}2.85^{* * * *} \\
(1.08)\end{array}$ & $\begin{array}{c}4.71^{* * *} \\
(1.42)\end{array}$ & $\begin{array}{c}4.09^{* * *} \\
(1.39)\end{array}$ \\
\hline High-skill wage & $\begin{array}{c}-2.46^{* * * *} \\
(0.77)\end{array}$ & $\begin{array}{l}-0.81 \\
(0.79)\end{array}$ & $\begin{array}{c}-2.30^{* *} \\
(0.99)\end{array}$ & $\begin{array}{l}-1.26 \\
(1.00)\end{array}$ & $\begin{array}{c}-2.78^{* *} \\
(1.39)\end{array}$ & $\begin{array}{l}-1.55 \\
(1.50)\end{array}$ \\
\hline GDP gap & $\begin{array}{c}-4.71^{*} \\
(2.73)\end{array}$ & $\begin{array}{l}-2.66 \\
(3.52)\end{array}$ & $\begin{array}{c}4.51 \\
(7.05)\end{array}$ & $\begin{array}{c}8.28 \\
(7.72)\end{array}$ & $\begin{array}{c}0.73 \\
(4.92)\end{array}$ & $\begin{array}{c}1.20 \\
(5.47)\end{array}$ \\
\hline Labor productivity & $\begin{array}{c}0.81 \\
(0.90)\end{array}$ & $\begin{array}{c}0.09 \\
(1.04)\end{array}$ & $\begin{array}{l}-1.32 \\
(1.67)\end{array}$ & $\begin{array}{l}-1.90 \\
(1.53)\end{array}$ & $\begin{array}{l}-1.66 \\
(1.48)\end{array}$ & $\begin{array}{l}-1.53 \\
(1.52)\end{array}$ \\
\hline Stock automation & No & Yes & No & Yes & No & Yes \\
\hline Stock other & Yes & Yes & Yes & Yes & Yes & Yes \\
\hline Spillovers & Yes & Yes & Yes & Yes & Yes & Yes \\
\hline Fixed effects & $\mathrm{F}+\mathrm{IY}$ & $\mathrm{F}+\mathrm{IY}$ & $\mathrm{F}+\mathrm{IY}+\mathrm{CY}$ & $\mathrm{F}+\mathrm{IY}+\mathrm{CY}$ & $\mathrm{F}+\mathrm{IY}+\mathrm{CY}$ & $\mathrm{F}+\mathrm{IY}+\mathrm{CY}$ \\
\hline Estimator & HHG & BGVR & HHG & BGVR & HHG & BGVR \\
\hline Observations & 49174 & 49174 & 48773 & 48787 & 48773 & 48787 \\
\hline Firms & 3329 & 3329 & 3324 & 3326 & 3324 & 3326 \\
\hline
\end{tabular}

Note: Marginal effects; Standard errors in parentheses. The independent variables are lagged by two periods. Estimation is by conditional Poisson regressions fixed-effects (HHG) in columns (1), (3), and (5). In columns (2), (4), and (6), estimation is done by Poisson regressions where the firm fixed effects are replaced by the pre-sample mean, following Blundell, Griffith and Van Reenen (1999, BGVR). Columns (1) and (2) include year-industry fixed effects and columns (3) to (6) include year-industry and country-year fixed effects. In Columns (5) and (6) the macroeconomic variables are the normalized foreign variables previously defined. Standard errors are clustered at the firm-level. ${ }^{*} p<0.1 ;{ }^{* *} p<0.05 ; * * * p<0.01$ 
Table A.11: Lags and leads

\begin{tabular}{|c|c|c|c|c|c|c|c|c|}
\hline \multirow{2}{*}{$\begin{array}{l}\text { Dependent variable } \\
\text { Lags (Leads) }\end{array}$} & \multicolumn{8}{|c|}{ Auto95 } \\
\hline & $\begin{array}{l}-5 \\
(1)\end{array}$ & $\begin{array}{l}-4 \\
(2)\end{array}$ & $\begin{array}{l}-3 \\
(3)\end{array}$ & $\begin{array}{l}-2 \\
(4)\end{array}$ & $\begin{array}{l}-1 \\
(5)\end{array}$ & $\begin{array}{c}0 \\
(6)\end{array}$ & $\begin{array}{c}1 \\
(7)\end{array}$ & $\begin{array}{c}2 \\
(8)\end{array}$ \\
\hline Low-skill wage & $\begin{array}{c}2.08^{* * *} \\
(0.76)\end{array}$ & $\begin{array}{c}2.53^{* * *} \\
(0.78)\end{array}$ & $\begin{array}{c}2.66^{* * *} \\
(0.81)\end{array}$ & $\begin{array}{c}2.67^{* * *} \\
(0.84)\end{array}$ & $\begin{array}{c}2.34^{* * *} \\
(0.83)\end{array}$ & $\begin{array}{c}2.60^{* * *} \\
(0.82)\end{array}$ & $\begin{array}{c}2.45^{* * *} \\
(0.84)\end{array}$ & $\begin{array}{l}1.48^{*} \\
(0.82)\end{array}$ \\
\hline High-skill wage & $\begin{array}{l}-1.23^{*} \\
(0.74)\end{array}$ & $\begin{array}{c}-2.16^{* * *} \\
(0.76)\end{array}$ & $\begin{array}{c}-3.04^{* * *} \\
(0.78)\end{array}$ & $\begin{array}{c}-2.61^{* * *} \\
(0.79)\end{array}$ & $\begin{array}{c}-2.75^{* * *} \\
(0.76)\end{array}$ & $\begin{array}{c}-3.12^{* * *} \\
(0.81)\end{array}$ & $\begin{array}{c}-2.94^{* * *} \\
(0.76)\end{array}$ & $\begin{array}{c}-2.80^{* * *} \\
(0.72)\end{array}$ \\
\hline Labor productivity & $\begin{array}{c}1.17 \\
(0.81)\end{array}$ & $\begin{array}{l}1.46^{*} \\
(0.84)\end{array}$ & $\begin{array}{l}2.11^{* *} \\
(0.88)\end{array}$ & $\begin{array}{c}0.91 \\
(0.92)\end{array}$ & $\begin{array}{c}0.54 \\
(0.89)\end{array}$ & $\begin{array}{c}0.11 \\
(0.91)\end{array}$ & $\begin{array}{c}0.03 \\
(0.93)\end{array}$ & $\begin{array}{c}0.51 \\
(0.92)\end{array}$ \\
\hline Fixed effects & $\mathrm{F}+\mathrm{IY}$ & $\mathrm{F}+\mathrm{IY}$ & $\mathrm{F}+\mathrm{IY}$ & $\mathrm{F}+\mathrm{IY}$ & $\mathrm{F}+\mathrm{IY}$ & $\mathrm{F}+\mathrm{IY}$ & $\mathrm{F}+\mathrm{IY}$ & $\mathrm{F}+\mathrm{IY}$ \\
\hline Observations & 46783 & 47422 & 48514 & 49174 & 49657 & 50216 & 51262 & 52659 \\
\hline \multirow[t]{2}{*}{ Firms } & 3156 & 3202 & 3279 & 3329 & 3368 & 3412 & 3490 & 3587 \\
\hline & \multicolumn{8}{|c|}{ Panel B: country-year fixed effects } \\
\hline Low-skill wage & $\begin{array}{l}1.81^{*} \\
(1.03)\end{array}$ & $\begin{array}{l}1.89^{*} \\
(1.10)\end{array}$ & $\begin{array}{l}2.15^{*} \\
(1.10)\end{array}$ & $\begin{array}{l}2.55^{* *} \\
(1.13)\end{array}$ & $\begin{array}{l}2.27^{* *} \\
(1.13)\end{array}$ & $\begin{array}{l}2.04^{*} \\
(1.12)\end{array}$ & $\begin{array}{c}1.85 \\
(1.15)\end{array}$ & $\begin{array}{c}0.88 \\
(1.10)\end{array}$ \\
\hline High-skill wage & $\begin{array}{l}-0.05 \\
(1.20)\end{array}$ & $\begin{array}{l}-1.32 \\
(1.12)\end{array}$ & $\begin{array}{l}-1.98^{*} \\
(1.03)\end{array}$ & $\begin{array}{c}-2.16^{* *} \\
(1.05)\end{array}$ & $\begin{array}{c}-2.51^{* *} \\
(1.15)\end{array}$ & $\begin{array}{c}-3.17^{* * *} \\
(1.15)\end{array}$ & $\begin{array}{c}-2.95^{* * *} \\
(1.06)\end{array}$ & $\begin{array}{c}-2.19^{* *} \\
(1.07)\end{array}$ \\
\hline \multirow[t]{2}{*}{ Labor productivity } & $\begin{array}{l}-1.91 \\
(1.65) \\
\end{array}$ & $\begin{array}{l}-1.03 \\
(1.58) \\
\end{array}$ & $\begin{array}{l}-0.70 \\
(1.58) \\
\end{array}$ & $\begin{array}{l}-1.68 \\
(1.76) \\
\end{array}$ & $\begin{array}{l}-0.92 \\
(1.85) \\
\end{array}$ & $\begin{array}{l}-0.17 \\
(1.75) \\
\end{array}$ & $\begin{array}{c}0.13 \\
(1.69) \\
\end{array}$ & $\begin{array}{l}-0.13 \\
(1.57) \\
\end{array}$ \\
\hline & \multicolumn{8}{|c|}{ Panel C: country-year fixed effects and foreign variables } \\
\hline Low-skill wage & $\begin{array}{c}2.41 \\
(1.50)\end{array}$ & $\begin{array}{l}3.04^{* *} \\
(1.52)\end{array}$ & $\begin{array}{c}4.05^{* * *} \\
(1.55)\end{array}$ & $\begin{array}{c}5.08^{* * *} \\
(1.54)\end{array}$ & $\begin{array}{l}3.82^{* *} \\
(1.55)\end{array}$ & $\begin{array}{l}2.80^{*} \\
(1.65)\end{array}$ & $\begin{array}{c}2.55 \\
(1.76)\end{array}$ & $\begin{array}{c}1.62 \\
(1.77)\end{array}$ \\
\hline High-skill wage & $\begin{array}{c}0.41 \\
(1.53)\end{array}$ & $\begin{array}{l}-2.12 \\
(1.50)\end{array}$ & $\begin{array}{c}-3.30^{* *} \\
(1.48)\end{array}$ & $\begin{array}{c}-2.95^{* *} \\
(1.46)\end{array}$ & $\begin{array}{c}-4.08^{* * *} \\
(1.56)\end{array}$ & $\begin{array}{c}-5.03^{* * *} \\
(1.56)\end{array}$ & $\begin{array}{c}-5.07^{* * *} \\
(1.52)\end{array}$ & $\begin{array}{c}-3.71^{* *} \\
(1.58)\end{array}$ \\
\hline Labor productivity & $\begin{array}{l}-1.77 \\
(1.64)\end{array}$ & $\begin{array}{l}-0.61 \\
(1.65)\end{array}$ & $\begin{array}{l}-0.92 \\
(1.61)\end{array}$ & $\begin{array}{l}-2.15 \\
(1.58)\end{array}$ & $\begin{array}{c}0.35 \\
(1.60)\end{array}$ & $\begin{array}{c}2.07 \\
(1.71)\end{array}$ & $\begin{array}{c}2.57 \\
(1.76)\end{array}$ & $\begin{array}{c}1.78 \\
(1.78)\end{array}$ \\
\hline Fixed effects & $\mathrm{F}+\mathrm{IY}+\mathrm{CY}$ & $\mathrm{F}+\mathrm{IY}+\mathrm{CY}$ & $\mathrm{F}+\mathrm{IY}+\mathrm{CY}$ & $\mathrm{F}+\mathrm{IY}+\mathrm{CY}$ & $\mathrm{F}+\mathrm{IY}+\mathrm{CY}$ & $\mathrm{F}+\mathrm{IY}+\mathrm{CY}$ & $\mathrm{F}+\mathrm{IY}+\mathrm{CY}$ & $\mathrm{F}+\mathrm{IY}+\mathrm{CY}$ \\
\hline Observations & 46461 & 47136 & 48172 & 48773 & 49236 & 49810 & 50857 & 52253 \\
\hline Firms & 3156 & 3202 & 3277 & 3324 & 3361 & 3406 & 3484 & 3584 \\
\hline
\end{tabular}

Marginal effects; Standard errors in parentheses. Each panel represents a different regression. All regressions contain controls for GDP gap, stocks and spillovers, for which we do not report the coefficients. The independent variables (wages, labor productivity, GDP gap and spillovers) are lagged by the number of periods indicated in lag, except for the stock variables which are always lagged by 2 periods. Estimation is done by conditional Poisson regressions fixed-effects (HHG). Panel A regressions contain firm and industry-year fixed effects. Panels B and $\mathrm{C}$ add country-year fixed effects. In Panel $\mathrm{C}$ the macroeconomic variables are their foreign normalized values previously definted. Standard errors are clustered at the firm-level. ${ }^{*} p<0.1 ; * * p<0.05 ;{ }^{* * *} p<0.01$ 
Table A.12: Placebo regressions: long leads

\begin{tabular}{|c|c|c|c|c|c|c|c|c|c|}
\hline \multirow[t]{3}{*}{ Dependent variable } & \multicolumn{9}{|c|}{ Auto95 } \\
\hline & \multicolumn{6}{|c|}{ Domestic+Foreign } & \multicolumn{3}{|c|}{ Foreign } \\
\hline & $\begin{array}{c}t+5 \\
(1)\end{array}$ & $\begin{array}{c}t+10 \\
(2)\end{array}$ & $\begin{array}{c}t+15 \\
(3)\end{array}$ & $\begin{array}{c}t+5 \\
(4)\end{array}$ & $\begin{array}{c}t+10 \\
(5)\end{array}$ & $\begin{array}{c}t+15 \\
(6)\end{array}$ & $\begin{array}{c}t+5 \\
(7)\end{array}$ & $\begin{array}{c}t+10 \\
(8)\end{array}$ & $\begin{array}{c}t+15 \\
\quad(9)\end{array}$ \\
\hline \multirow[t]{2}{*}{ Low-skill wage } & -0.34 & -1.77 & -1.39 & -0.41 & -1.35 & $-1.71^{* *}$ & 0.65 & 2.44 & 0.81 \\
\hline & $(0.79)$ & $(1.08)$ & $(1.13)$ & $(0.66)$ & $(0.83)$ & $(0.78)$ & $(1.32)$ & $(1.78)$ & $(1.95)$ \\
\hline \multirow[t]{2}{*}{ High-skill wage } & $1.83^{* *}$ & 0.53 & -0.64 & 0.12 & 0.68 & -0.33 & $2.62^{* *}$ & -1.36 & -1.67 \\
\hline & $(0.89)$ & $(1.54)$ & $(1.27)$ & $(0.58)$ & $(0.89)$ & $(0.81)$ & $(1.19)$ & $(2.03)$ & $(2.03)$ \\
\hline \multirow[t]{2}{*}{ GDP gap } & -0.91 & 3.36 & 3.24 & -4.01 & -0.34 & $7.88^{* * *}$ & 2.05 & $7.82^{*}$ & 5.61 \\
\hline & $(8.66)$ & $(6.29)$ & $(5.70)$ & $(3.17)$ & $(2.64)$ & $(3.04)$ & $(4.14)$ & $(4.41)$ & $(4.12)$ \\
\hline \multirow[t]{2}{*}{ Labor productivity } & -1.04 & 1.27 & -0.38 & 0.61 & -0.07 & -0.57 & $-2.33^{*}$ & $-4.24^{* * *}$ & -2.51 \\
\hline & $(1.14)$ & $(1.91)$ & $(1.73)$ & $(0.77)$ & $(0.94)$ & $(0.96)$ & $(1.29)$ & $(1.47)$ & $(1.54)$ \\
\hline Stocks / Spillovers & Yes & Yes & Yes & Yes & Yes & Yes & Yes & Yes & Yes \\
\hline Fixed effects & $\mathrm{F}+\mathrm{IY}$ & $\mathrm{F}+\mathrm{IY}$ & $\mathrm{F}+\mathrm{IY}$ & $\mathrm{F}+\mathrm{IY}+\mathrm{CY}$ & $\mathrm{F}+\mathrm{IY}+\mathrm{CY}$ & $\mathrm{F}+\mathrm{IY}+\mathrm{CY}$ & $\mathrm{F}+\mathrm{IY}+\mathrm{CY}$ & $\mathrm{F}+\mathrm{IY}+\mathrm{CY}$ & $\mathrm{F}+\mathrm{IY}+\mathrm{CY}$ \\
\hline Observations & 51124 & 59393 & 62059 & 51506 & 59917 & 62670 & 51124 & 59393 & 62059 \\
\hline Firms & 3850 & 4177 & 4284 & 3859 & 4183 & 4290 & 3850 & 4177 & 4284 \\
\hline
\end{tabular}

Note: Marginal effects; Standard errors in parentheses. The independent variables are led by 5 periods (Columns (1), (4) and (5) 10 periods (Columns (2), (5) and (8)) or 15 periods (Columns (3), (6) and (9)), except the stock variables which are lagged b two periods. Estimation is done by conditional Poisson fixed-effects regressions (HHG). Columns (1)-(3) include firm and industry year fixed effects, while (4)-(9) include firm, industry-year, and country-year fixed effects. In Columns (7)-(9), the macroeconomi variables are the normalized foreign variables previously defined. Standard errors are clustered at the firm-level. ${ }^{*} p<0.1 ;{ }^{* *} p<$ $0.05 ; * * * p<0.01$

Table A.13: Predicted wages

\begin{tabular}{|c|c|c|c|c|c|c|c|c|c|}
\hline \multirow[t]{3}{*}{ "Dependent variable } & \multicolumn{9}{|c|}{ Auto95 } \\
\hline & \multicolumn{6}{|c|}{ Domestic+Foreign } & \multicolumn{3}{|c|}{ Foreign } \\
\hline & (1) & (2) & (3) & (4) & (5) & (6) & (7) & (8) & (9) \\
\hline Low-skill wage & $\begin{array}{c}2.38^{* * *} \\
(0.80)\end{array}$ & $\begin{array}{l}1.77^{* *} \\
(0.81)\end{array}$ & $\begin{array}{c}2.40^{* * *} \\
(0.81)\end{array}$ & $\begin{array}{l}1.60^{*} \\
(0.92)\end{array}$ & $\begin{array}{c}1.47 \\
(1.01)\end{array}$ & $\begin{array}{l}1.61^{*} \\
(0.93)\end{array}$ & $\begin{array}{c}3.79^{* * *} \\
(1.28)\end{array}$ & $\begin{array}{c}4.03^{* * *} \\
(1.37)\end{array}$ & $\begin{array}{c}3.78^{* * *} \\
(1.29)\end{array}$ \\
\hline High-skill wage & $\begin{array}{c}-2.77^{* * *} \\
(0.81)\end{array}$ & $\begin{array}{c}-4.79^{* * * *} \\
(1.08)\end{array}$ & $\begin{array}{c}-2.81^{* * *} \\
(0.82)\end{array}$ & $\begin{array}{c}-3.38^{* * * *} \\
(1.01)\end{array}$ & $\begin{array}{c}-3.78^{* * * *} \\
(1.38)\end{array}$ & $\begin{array}{c}-3.39^{* * *} \\
(1.02)\end{array}$ & $\begin{array}{c}-4.35^{* * *} \\
(1.31)\end{array}$ & $\begin{array}{c}-3.79^{* * *} \\
(1.52)\end{array}$ & $\begin{array}{c}-4.34^{* * * *} \\
(1.32)\end{array}$ \\
\hline GDP gap & $\begin{array}{l}-4.90^{*} \\
(2.56)\end{array}$ & $\begin{array}{l}-4.23^{*} \\
(2.51)\end{array}$ & $\begin{array}{l}-4.95^{*} \\
(2.56)\end{array}$ & $\begin{array}{c}4.10 \\
(6.78)\end{array}$ & $\begin{array}{c}4.09 \\
(6.79)\end{array}$ & $\begin{array}{c}4.11 \\
(6.78)\end{array}$ & $\begin{array}{l}-0.86 \\
(4.45)\end{array}$ & $\begin{array}{l}-0.36 \\
(4.51)\end{array}$ & $\begin{array}{l}-0.81 \\
(4.49)\end{array}$ \\
\hline Labor productivity & & $\begin{array}{c}2.92^{* * *} \\
(0.95)\end{array}$ & & & $\begin{array}{c}0.59 \\
(1.54)\end{array}$ & & & $\begin{array}{l}-0.92 \\
(1.48)\end{array}$ & \\
\hline GDP per capita & & & $\begin{array}{c}0.12 \\
(0.10)\end{array}$ & & & $\begin{array}{c}0.02 \\
(0.12)\end{array}$ & & & $\begin{array}{l}-0.02 \\
(0.14)\end{array}$ \\
\hline Stocks / Spillovers & Yes & Yes & Yes & Yes & Yes & Yes & Yes & Yes & Yes \\
\hline Fixed effects & $\mathrm{F}+\mathrm{IY}$ & $\mathrm{F}+\mathrm{IY}$ & $\mathrm{F}+\mathrm{IY}$ & $\mathrm{F}+\mathrm{IY}+\mathrm{CY}$ & $\mathrm{F}+\mathrm{IY}+\mathrm{CY}$ & $\mathrm{F}+\mathrm{IY}+\mathrm{CY}$ & $\mathrm{F}+\mathrm{IY}+\mathrm{CY}$ & $\mathrm{F}+\mathrm{IY}+\mathrm{CY}$ & $\mathrm{F}+\mathrm{IY}+\mathrm{CY}$ \\
\hline Observations & 49174 & 49174 & 49174 & 48773 & 48773 & 48773 & 48773 & 48773 & 48773 \\
\hline Firms & 3329 & 3329 & 3329 & 3324 & 3324 & 3324 & 3324 & 3324 & 3324 \\
\hline
\end{tabular}

Note: Marginal effects; Standard errors in parentheses. The independent variables are lagged by two periods. Estimation is done by conditional Poisson fixed-effects regressions (HHG). We estimate for each country an AR(1) process with time trends for wages, labor productivity, and GDP per capita. We then use the estimated process to predict with the information available at time t-2 the average values between the years $t+2$ and $t+7$, which are in turn the independent variables in these regressions. Columns (1)-(3) include firm and industry-year fixed effects, while (4)-(9) include firm, industry-year, and country-year fixed effects. In Columns (7)-(9) the macroeconomic variables are the normalized foreign variables previously defined. Stock and spillover variables are calculated with respect to the dependent variable. Standard errors are clustered at the firm-level. ${ }^{*} p<0.1 ;{ }^{* *} p<0.05 ;{ }^{* *} p<0.01$ 
Table A.14: Minimum wage

\begin{tabular}{|c|c|c|c|c|c|c|c|c|c|}
\hline \multirow[t]{3}{*}{ Dependent variable } & \multicolumn{9}{|c|}{ Auto95 } \\
\hline & \multicolumn{6}{|c|}{ Domestic+Foreign } & \multicolumn{3}{|c|}{ Foreign } \\
\hline & (1) & $(2)$ & (3) & (4) & (5) & $(6)$ & (7) & (8) & (9) \\
\hline Minimum wage & $\begin{array}{c}2.10^{* * *} \\
(0.62)\end{array}$ & $\begin{array}{c}1.85^{* * *} \\
(0.63)\end{array}$ & $\begin{array}{c}2.11^{* * *} \\
(0.78)\end{array}$ & $\begin{array}{l}1.79^{* *} \\
(0.88)\end{array}$ & $\begin{array}{l}1.92^{* *} \\
(0.92)\end{array}$ & $\begin{array}{l}1.92^{*} \\
(1.04)\end{array}$ & $\begin{array}{l}2.15^{*} \\
(1.17)\end{array}$ & $\begin{array}{l}2.20^{*} \\
(1.24)\end{array}$ & $\begin{array}{c}0.92 \\
(1.38)\end{array}$ \\
\hline High-skill wage & $\begin{array}{c}-1.88^{* * *} \\
(0.66)\end{array}$ & $\begin{array}{c}-2.50^{* * *} \\
(0.79)\end{array}$ & $\begin{array}{c}-1.86^{* *} \\
(0.82)\end{array}$ & $\begin{array}{c}-3.69^{* * *} \\
(1.01)\end{array}$ & $\begin{array}{c}-3.17^{* * *} \\
(1.22)\end{array}$ & $\begin{array}{c}-3.46^{* *} \\
(1.40)\end{array}$ & $\begin{array}{c}-3.35^{* *} \\
(1.36)\end{array}$ & $\begin{array}{l}-3.19^{*} \\
(1.84)\end{array}$ & $\begin{array}{c}-5.35^{* * *} \\
(1.85)\end{array}$ \\
\hline GDP gap & $\begin{array}{l}-2.99 \\
(2.46)\end{array}$ & $\begin{array}{l}-3.89 \\
(2.55)\end{array}$ & $\begin{array}{l}-2.96 \\
(2.74)\end{array}$ & $\begin{array}{c}7.05 \\
(6.42)\end{array}$ & $\begin{array}{c}7.72 \\
(6.50)\end{array}$ & $\begin{array}{c}7.55 \\
(7.00)\end{array}$ & $\begin{array}{c}2.79 \\
(4.72)\end{array}$ & $\begin{array}{c}2.97 \\
(5.21)\end{array}$ & $\begin{array}{l}-2.52 \\
(6.10)\end{array}$ \\
\hline Labor productivity & & $\begin{array}{c}1.22 \\
(0.79)\end{array}$ & & & $\begin{array}{l}-0.94 \\
(1.48)\end{array}$ & & & $\begin{array}{l}-0.20 \\
(1.62)\end{array}$ & \\
\hline GDP per capita & & & $\begin{array}{c}-0.04 \\
(1.22) \\
\end{array}$ & & & $\begin{array}{l}-0.47 \\
(1.98)\end{array}$ & & & $\begin{array}{l}4.11^{*} \\
(2.49)\end{array}$ \\
\hline Stocks / Spillovers & Yes & Yes & Yes & Yes & Yes & Yes & Yes & Yes & Yes \\
\hline Fixed effects & $\mathrm{F}+\mathrm{IY}$ & $\mathrm{F}+\mathrm{IY}$ & $\mathrm{F}+\mathrm{IY}$ & $\mathrm{F}+\mathrm{IY}+\mathrm{CY}$ & $\mathrm{F}+\mathrm{IY}+\mathrm{CY}$ & $\mathrm{F}+\mathrm{IY}+\mathrm{CY}$ & $\mathrm{F}+\mathrm{IY}+\mathrm{CY}$ & $\mathrm{F}+\mathrm{IY}+\mathrm{CY}$ & $\mathrm{F}+\mathrm{IY}+\mathrm{CY}$ \\
\hline Observations & 49129 & 49129 & 49129 & 48757 & 48757 & 48757 & 47577 & 47577 & 47577 \\
\hline Firms & 3326 & 3326 & 3326 & 3322 & 3322 & 3322 & 3237 & 3237 & 3237 \\
\hline
\end{tabular}

Note: Marginal effects; Standard errors in parentheses. The independent variables are lagged by two periods. Estimation is done by conditional Poisson fixed effects regressions (HHG). Columns (1)-(3) include firm and year-industry fixed effects, while (4)-(9) include firm, year-industry, and country-year fixed effects. In Columns (7)-(9) the macroeconomic variables are the normalized foreign variables previously defined. Standard errors are clustered at the firm level. ${ }^{*} p<0.1 ;{ }^{* *} p<0.05 ;{ }^{* * *} p<0.01$

Table A.17: Citations-weighted patents

\begin{tabular}{|c|c|c|c|c|c|c|c|c|c|}
\hline \multirow[t]{3}{*}{ Dependent variable } & \multicolumn{9}{|c|}{ Citations-weighted auto95 } \\
\hline & \multicolumn{6}{|c|}{ Domestic+Foreign } & \multicolumn{3}{|c|}{ Foreign } \\
\hline & (1) & $(2)$ & (3) & (4) & $(5)$ & (6) & (7) & $(8)$ & (9) \\
\hline Low-skill wage & $\begin{array}{l}2.06^{* *} \\
(1.00)\end{array}$ & $\begin{array}{c}1.79 \\
(1.10)\end{array}$ & $\begin{array}{c}3.28^{* * *} \\
(1.14)\end{array}$ & $\begin{array}{c}1.28 \\
(1.22)\end{array}$ & $\begin{array}{c}1.62 \\
(1.45)\end{array}$ & $\begin{array}{l}3.53^{* *} \\
(1.50)\end{array}$ & $\begin{array}{l}3.39^{* *} \\
(1.72)\end{array}$ & $\begin{array}{l}4.16^{* *} \\
(1.87)\end{array}$ & $\begin{array}{l}3.80^{*} \\
(2.21)\end{array}$ \\
\hline High-skill wage & $\begin{array}{c}-2.38^{* *} \\
(0.96)\end{array}$ & $\begin{array}{c}-2.88^{* * *} \\
(0.99)\end{array}$ & $\begin{array}{l}-0.97 \\
(1.07)\end{array}$ & $\begin{array}{c}-3.26^{* *} \\
(1.27)\end{array}$ & $\begin{array}{l}-2.41^{*} \\
(1.30)\end{array}$ & $\begin{array}{l}-1.71 \\
(1.40)\end{array}$ & $\begin{array}{c}-4.00^{* *} \\
(1.64)\end{array}$ & $\begin{array}{l}-3.02 \\
(1.89)\end{array}$ & $\begin{array}{c}-3.77^{* *} \\
(1.76)\end{array}$ \\
\hline GDP gap & $\begin{array}{l}-3.80 \\
(3.15)\end{array}$ & $\begin{array}{l}-4.47 \\
(3.36)\end{array}$ & $\begin{array}{l}-0.74 \\
(3.26)\end{array}$ & $\begin{array}{c}0.53 \\
(7.80)\end{array}$ & $\begin{array}{c}1.75 \\
(7.97)\end{array}$ & $\begin{array}{c}4.62 \\
(7.98)\end{array}$ & $\begin{array}{l}-0.69 \\
(5.06)\end{array}$ & $\begin{array}{c}1.01 \\
(5.47)\end{array}$ & $\begin{array}{c}0.11 \\
(5.71)\end{array}$ \\
\hline Labor productivity & & $\begin{array}{c}1.15 \\
(1.23)\end{array}$ & & & $\begin{array}{l}-1.90 \\
(2.29)\end{array}$ & & & $\begin{array}{l}-1.63 \\
(1.80)\end{array}$ & \\
\hline GDP per capita & & & $\begin{array}{c}-3.54^{* *} \\
(1.63)\end{array}$ & & & $\begin{array}{c}-5.60^{* *} \\
(2.35)\end{array}$ & & & $\begin{array}{l}-0.71 \\
(2.61)\end{array}$ \\
\hline Stocks / Spillovers & Yes & Yes & Yes & Yes & Yes & Yes & & & \\
\hline Fixed effects & $\mathrm{F}+\mathrm{IY}$ & $\mathrm{F}+\mathrm{IY}$ & $\mathrm{F}+\mathrm{IY}$ & $\mathrm{F}+\mathrm{IY}+\mathrm{CY}$ & $\mathrm{F}+\mathrm{IY}+\mathrm{CY}$ & $\mathrm{F}+\mathrm{IY}+\mathrm{CY}$ & $\mathrm{F}+\mathrm{IY}+\mathrm{CY}$ & $\mathrm{F}+\mathrm{IY}+\mathrm{CY}$ & $\mathrm{F}+\mathrm{IY}+\mathrm{CY}$ \\
\hline Observations & 49174 & 49174 & 49174 & 48773 & 48773 & 48773 & 48773 & 48773 & 48773 \\
\hline Firms & 3329 & 3329 & 3329 & 3324 & 3324 & 3324 & 3324 & 3324 & 3324 \\
\hline
\end{tabular}

Note: Marginal effects; Standard errors in parentheses. The independent variables are lagged by two periods. Estimation is done by conditional Poisson fixed-effects regressions (HHG). Patents are citations-weighted: we add to each patent the number of citations received within 5 years normalized by technological field and year of application. Columns (1)-(3) include firm and industry-year fixed effects, while (4)-(9) include firm, industry-year, and country-year fixed effects. In Columns (7)-(9) the macroeconomic variables are the normalized foreign variables previously defined. Standard errors are clustered at the firm-level. ${ }^{*} p<0.1 ;{ }^{* *} p<0.05 ; * * * p<0.01$ 
Table A.15: Five-year difference estimation

\begin{tabular}{|c|c|c|c|c|c|c|c|c|c|}
\hline \multirow[t]{3}{*}{ Dependent Variable } & \multicolumn{9}{|c|}{$\Delta$ Arcsinhauto95 } \\
\hline & \multicolumn{6}{|c|}{ Domestic + Foreign } & \multicolumn{3}{|c|}{ Foreign } \\
\hline & (1) & $(2)$ & $(3)$ & (4) & $(5)$ & (6) & (7) & (8) & $(9)$ \\
\hline \multicolumn{10}{|c|}{ Panel A: Firms which patented at least once in 1995-2013 } \\
\hline$\Delta$ Low-skill wage & $\begin{array}{c}0.94^{* * *} \\
(0.27)\end{array}$ & $\begin{array}{c}0.91^{* * *} \\
(0.29)\end{array}$ & $\begin{array}{c}0.98^{* * *} \\
(0.32)\end{array}$ & $\begin{array}{c}0.70^{* *} \\
(0.34)\end{array}$ & $\begin{array}{c}0.59 \\
(0.37)\end{array}$ & $\begin{array}{c}0.49 \\
(0.43)\end{array}$ & $\begin{array}{c}1.10^{* *} \\
(0.49)\end{array}$ & $\begin{array}{c}0.74 \\
(0.56)\end{array}$ & $\begin{array}{c}0.46 \\
(0.61)\end{array}$ \\
\hline$\Delta$ High-skill wage & $\begin{array}{c}-0.95^{* * *} \\
(0.25)\end{array}$ & $\begin{array}{c}-1.00^{* * *} \\
(0.28)\end{array}$ & $\begin{array}{c}-0.91^{* * *} \\
(0.28)\end{array}$ & $\begin{array}{c}-0.99^{* * *} \\
(0.35)\end{array}$ & $\begin{array}{c}-1.21^{* * *} \\
(0.40)\end{array}$ & $\begin{array}{c}-1.14^{* * *} \\
(0.38)\end{array}$ & $\begin{array}{c}-1.20^{* *} \\
(0.51)\end{array}$ & $\begin{array}{c}-1.62^{* * *} \\
(0.58)\end{array}$ & $\begin{array}{c}-1.60^{* * *} \\
(0.54)\end{array}$ \\
\hline$\Delta$ GDP gap & $\begin{array}{l}-1.45 \\
(1.07)\end{array}$ & $\begin{array}{l}-1.55 \\
(1.07)\end{array}$ & $\begin{array}{l}-1.38 \\
(1.15)\end{array}$ & $\begin{array}{l}-0.19 \\
(2.18)\end{array}$ & $\begin{array}{l}-0.50 \\
(2.19)\end{array}$ & $\begin{array}{l}-0.36 \\
(2.22)\end{array}$ & $\begin{array}{l}-0.41 \\
(1.42)\end{array}$ & $\begin{array}{l}-1.27 \\
(1.65)\end{array}$ & $\begin{array}{l}-1.80 \\
(1.74)\end{array}$ \\
\hline$\Delta$ Labor productivity & & $\begin{array}{c}0.12 \\
(0.39)\end{array}$ & & & $\begin{array}{c}0.50 \\
(0.59)\end{array}$ & & & $\begin{array}{c}0.75 \\
(0.56)\end{array}$ & \\
\hline$\Delta$ GDP per capita & & & $\begin{array}{c}-0.10 \\
(0.44) \\
\end{array}$ & & & $\begin{array}{c}0.54 \\
(0.60) \\
\end{array}$ & & & $\begin{array}{l}1.22^{*} \\
(0.66) \\
\end{array}$ \\
\hline Fixed effects & IY & IY & IY & $\mathrm{CY}+\mathrm{IY}$ & $\mathrm{CY}+\mathrm{IY}$ & $\mathrm{CY}+\mathrm{IY}$ & $\mathrm{CY}+\mathrm{IY}$ & $\mathrm{CY}+\mathrm{IY}$ & $\mathrm{CY}+\mathrm{IY}$ \\
\hline Spillovers & Yes & Yes & Yes & Yes & Yes & Yes & Yes & Yes & Yes \\
\hline Observations & 35310 & 35310 & 35310 & 35280 & 35280 & 35280 & 35280 & 35280 & 35280 \\
\hline Firms & 3531 & 3531 & 3531 & 3528 & 3528 & 3528 & 3528 & 3528 & 3528 \\
\hline \multicolumn{10}{|c|}{ Panel B: Firms which patented at least twice in 1995-2013 } \\
\hline$\Delta$ Low-skill wage & $\begin{array}{c}1.87^{* * *} \\
(0.43)\end{array}$ & $\begin{array}{c}1.86^{* * *} \\
(0.47)\end{array}$ & $\begin{array}{c}1.87^{* * *} \\
(0.53)\end{array}$ & $\begin{array}{c}1.42^{* * *} \\
(0.54)\end{array}$ & $\begin{array}{c}1.40^{* *} \\
(0.60)\end{array}$ & $\begin{array}{l}1.26^{*} \\
(0.70)\end{array}$ & $\begin{array}{c}2.43^{* * *} \\
(0.76)\end{array}$ & $\begin{array}{c}1.96^{* *} \\
(0.88)\end{array}$ & $\begin{array}{l}1.74^{*} \\
(0.96)\end{array}$ \\
\hline$\Delta$ High-skill wage & $\begin{array}{c}-1.74^{* * *} \\
(0.39)\end{array}$ & $\begin{array}{c}-1.75^{* * *} \\
(0.44)\end{array}$ & $\begin{array}{c}-1.74^{* * *} \\
(0.45)\end{array}$ & $\begin{array}{c}-1.88^{* * *} \\
(0.56)\end{array}$ & $\begin{array}{c}-1.92^{* * *} \\
(0.64)\end{array}$ & $\begin{array}{c}-2.00^{* * *} \\
(0.61)\end{array}$ & $\begin{array}{c}-2.36^{* * *} \\
(0.77)\end{array}$ & $\begin{array}{c}-2.91 * * * \\
(0.89)\end{array}$ & $\begin{array}{c}-2.79^{* * *} \\
(0.84)\end{array}$ \\
\hline$\Delta$ GDP gap & $\begin{array}{l}-2.38 \\
(1.46)\end{array}$ & $\begin{array}{l}-2.39 \\
(1.47)\end{array}$ & $\begin{array}{l}-2.37 \\
(1.60)\end{array}$ & $\begin{array}{l}-2.06 \\
(3.20)\end{array}$ & $\begin{array}{l}-2.11 \\
(3.24)\end{array}$ & $\begin{array}{l}-2.19 \\
(3.28)\end{array}$ & $\begin{array}{l}-0.81 \\
(2.09)\end{array}$ & $\begin{array}{l}-1.92 \\
(2.46)\end{array}$ & $\begin{array}{l}-2.29 \\
(2.61)\end{array}$ \\
\hline$\Delta$ Labor productivity & & $\begin{array}{c}0.02 \\
(0.60)\end{array}$ & & & $\begin{array}{c}0.09 \\
(0.94)\end{array}$ & & & $\begin{array}{c}0.96 \\
(0.89)\end{array}$ & \\
\hline$\Delta$ GDP per capita & & & $\begin{array}{l}-0.01 \\
(0.71)\end{array}$ & & & $\begin{array}{c}0.42 \\
(0.98)\end{array}$ & & & $\begin{array}{c}1.28 \\
(1.06)\end{array}$ \\
\hline Fixed effects & IY & IY & IY & $\mathrm{CY}+\mathrm{IY}$ & $\mathrm{CY}+\mathrm{IY}$ & $\mathrm{CY}+\mathrm{IY}$ & $\mathrm{CY}+\mathrm{IY}$ & $\mathrm{CY}+\mathrm{IY}$ & $\mathrm{CY}+\mathrm{IY}$ \\
\hline Spillovers & Yes & Yes & Yes & Yes & Yes & Yes & Yes & Yes & Yes \\
\hline Observations & 22650 & 22650 & 22650 & 22630 & 22630 & 22630 & 22630 & 22630 & 22630 \\
\hline Firms & 2265 & 2265 & 2265 & 2263 & 2263 & 2263 & 2263 & 2263 & 2263 \\
\hline
\end{tabular}

Note: Marginal effects; Standard errors in parentheses. Estimation is done by OLS. $t=2000-2009$ : The dependent variable is the difference between the arcsinh of the sum of yearly auto95 patents in $t$ to $t+4$ and the arcsinh of the sum of yearly auto95 patents in $t-5$ to $t-1$. Columns (1)-(3) include industry-year fixed effect, while (4)-(9) include industry-year and country-year fixed effects. In Columns (7) to (9) the macroeconomic variables are the normalized foreign variables previously defined. All the independent variables are the sum of yearly counterparts from $t-4$ to $t$. Standard errors are clustered at the firm-level. ${ }^{*} p<0.1{ }^{* *} p<0.05 ;{ }^{* * *} p<0.01$ 
Table A.18: Wages and deflators

\begin{tabular}{|c|c|c|c|c|c|}
\hline \multirow{2}{*}{$\begin{array}{l}\text { Dependent variable } \\
\text { Sector }\end{array}$} & \multicolumn{5}{|c|}{ Auto95 } \\
\hline & \multicolumn{3}{|c|}{ Manufacturing } & \multicolumn{2}{|c|}{ Total } \\
\hline Deflator & $\begin{array}{l}\text { Manufacturing PPI, } \\
\text { conversion in } 2005 \\
\text { (1) }\end{array}$ & $\begin{array}{l}\text { US manufacturing PPI, } \\
\text { conversion every year } \\
(2)\end{array}$ & $\begin{array}{c}\text { GDP deflator, } \\
\text { conversion in } 1995 \\
(3)\end{array}$ & $\begin{array}{c}\text { Manufacturing PPI, } \\
\text { conversion in } 1995 \\
(4)\end{array}$ & $\begin{array}{c}\text { US manufacturing PPI, } \\
\text { conversion every year } \\
(5)\end{array}$ \\
\hline Foreign: & & & & & \\
\hline Low-skill wage & $\begin{array}{c}5.00^{* * *} \\
(1.51)\end{array}$ & $\begin{array}{c}4.24^{* * *} \\
(1.41)\end{array}$ & $\begin{array}{l}4.88^{* *} \\
(1.93)\end{array}$ & $\begin{array}{l}5.23^{*} \\
(2.80)\end{array}$ & $\begin{array}{l}4.75^{* *} \\
(2.03)\end{array}$ \\
\hline High-skill wage & $\begin{array}{c}-2.68^{*} \\
(1.38)\end{array}$ & $\begin{array}{c}-3.60^{* *} \\
(1.42)\end{array}$ & $\begin{array}{c}-2.58^{*} \\
(1.48)\end{array}$ & $\begin{array}{l}-2.58 \\
(2.27)\end{array}$ & $\begin{array}{l}-3.43 \\
(2.23)\end{array}$ \\
\hline GDP gap & $\begin{array}{c}1.53 \\
(4.78)\end{array}$ & $\begin{array}{c}0.49 \\
(4.82)\end{array}$ & $\begin{array}{c}1.40 \\
(4.84)\end{array}$ & $\begin{array}{c}0.15 \\
(4.42)\end{array}$ & $\begin{array}{l}-0.52 \\
(4.55)\end{array}$ \\
\hline Labor productivity & $\begin{array}{l}-2.40 \\
(1.51)\end{array}$ & $\begin{array}{l}-1.10 \\
(1.56)\end{array}$ & $\begin{array}{l}-2.32 \\
(1.62)\end{array}$ & $\begin{array}{l}-2.85 \\
(3.06)\end{array}$ & $\begin{array}{l}-2.24 \\
(2.90)\end{array}$ \\
\hline Stocks / Spillovers & Yes & Yes & Yes & Yes & Yes \\
\hline Fixed effects & $\mathrm{F}+\mathrm{IY}+\mathrm{CY}$ & $\mathrm{F}+\mathrm{IY}+\mathrm{CY}$ & $\mathrm{F}+\mathrm{IY}+\mathrm{CY}$ & $\mathrm{F}+\mathrm{IY}+\mathrm{CY}$ & $\mathrm{F}+\mathrm{IY}+\mathrm{CY}$ \\
\hline Observations & 48773 & 48773 & 48773 & 48773 & 48773 \\
\hline Firms & 3324 & 3324 & 3324 & 3324 & 3324 \\
\hline
\end{tabular}

Note: All regressions include firm fixed effects, industry-year fixed effects and country-year fixed effects. Columns (1) to (3) use manufacturing wages and Columns (4) and (5) on total wages. In Column (1), macroeconomic variables are deflated with the local manufacturing PPI and converted to USD in 2005. In Columns (2) and (5) they are converted to USD every year and deflated with the US manufacturing PPI. In Column (3), macroeconomic variables are deflated with the local GDP deflator and converted to USD in 1995. In Column (4), macroeconomic variables are deflated with the local manufacturing PPI and converted to USD in 1995. In all columns, the macroeconomic variables are the normalized foreign variables previously defined. Standard errors are clustered at the firm-level. ${ }^{*} p<0.1 ;{ }^{* *} p<0.05 ;{ }^{* * *} p<0.01$

Table A.19: Firm bin size - year fixed effects

\begin{tabular}{|c|c|c|c|c|c|c|c|c|c|}
\hline \multirow[t]{3}{*}{ Dependent Variable } & \multicolumn{9}{|c|}{ Auto95 } \\
\hline & \multicolumn{6}{|c|}{ Domestic + Foreign } & \multicolumn{3}{|c|}{ Foreign } \\
\hline & (1) & $(2)$ & (3) & (4) & (5) & (6) & (7) & $(8)$ & (9) \\
\hline Low-skill wage & $\begin{array}{c}3.03^{* * *} \\
(0.79)\end{array}$ & $\begin{array}{c}2.78^{* * *} \\
(0.84)\end{array}$ & $\begin{array}{c}3.56^{* * *} \\
(0.95)\end{array}$ & $\begin{array}{c}2.31^{* *} \\
(0.98)\end{array}$ & $\begin{array}{c}2.70^{* *} \\
(1.12)\end{array}$ & $\begin{array}{c}3.57^{* * *} \\
(1.24)\end{array}$ & $\begin{array}{c}4.34^{* * *} \\
(1.31)\end{array}$ & $\begin{array}{c}5.51^{* * *} \\
(1.54)\end{array}$ & $\begin{array}{l}4.36^{* *} \\
(1.77)\end{array}$ \\
\hline High-skill wage & $\begin{array}{c}-2.29^{* * *} \\
(0.71)\end{array}$ & $\begin{array}{c}-2.70^{* * *} \\
(0.77)\end{array}$ & $\begin{array}{c}-1.77^{* *} \\
(0.79)\end{array}$ & $\begin{array}{c}-2.85^{* * *} \\
(0.94)\end{array}$ & $\begin{array}{l}-2.01^{*} \\
(1.07)\end{array}$ & $\begin{array}{l}-2.02^{*} \\
(1.04)\end{array}$ & $\begin{array}{c}-4.52^{* * *} \\
(1.32)\end{array}$ & $\begin{array}{l}-2.87^{*} \\
(1.47)\end{array}$ & $\begin{array}{c}-4.50^{* * *} \\
(1.40)\end{array}$ \\
\hline GDP gap & $\begin{array}{l}-3.32 \\
(2.67)\end{array}$ & $\begin{array}{l}-3.89 \\
(2.78)\end{array}$ & $\begin{array}{l}-2.11 \\
(2.83)\end{array}$ & $\begin{array}{c}3.95 \\
(6.76)\end{array}$ & $\begin{array}{c}5.01 \\
(6.80)\end{array}$ & $\begin{array}{l}6.11 \\
(7.06)\end{array}$ & $\begin{array}{l}-0.68 \\
(4.54)\end{array}$ & $\begin{array}{c}1.78 \\
(4.81)\end{array}$ & $\begin{array}{l}-0.63 \\
(5.15)\end{array}$ \\
\hline Labor productivity & & $\begin{array}{c}0.99 \\
(0.90)\end{array}$ & & & $\begin{array}{l}-1.92 \\
(1.77)\end{array}$ & & & $\begin{array}{l}-2.67^{*} \\
(1.62)\end{array}$ & \\
\hline GDP per capita & & & $\begin{array}{l}-1.46 \\
(1.30) \\
\end{array}$ & & & $\begin{array}{l}-3.09 \\
(1.90) \\
\end{array}$ & & & $\begin{array}{l}-0.04 \\
(2.06) \\
\end{array}$ \\
\hline $\begin{array}{l}\text { Stocks / Spillovers } \\
\text { Fixed effects }\end{array}$ & $\begin{array}{c}\text { Yes } \\
\mathrm{F}+\mathrm{IY} \\
\mathrm{BY}\end{array}$ & $\begin{array}{c}\text { Yes } \\
\mathrm{F}+\mathrm{IY} \\
\mathrm{BY}\end{array}$ & $\begin{array}{c}\text { Yes } \\
\text { F+IY } \\
\text { BY }\end{array}$ & $\begin{array}{c}\text { Yes } \\
\text { F+IY } \\
\text { BY }\end{array}$ & $\begin{array}{c}\text { Yes } \\
\text { F+IY } \\
\text { BY }\end{array}$ & $\begin{array}{c}\text { Yes } \\
\text { F+IY } \\
\text { BY }\end{array}$ & $\begin{array}{c}\text { Yes } \\
\text { F+IY } \\
\text { BY+CY }\end{array}$ & $\begin{array}{c}\text { Yes } \\
\mathrm{F}+\mathrm{IY} \\
\mathrm{BY}+\mathrm{CY}\end{array}$ & $\begin{array}{c}\text { Yes } \\
\text { F+IY } \\
\text { BY+CY }\end{array}$ \\
\hline Observations & 49935 & 49935 & 49935 & 49890 & 49890 & 49890 & 49890 & 49890 & 49890 \\
\hline Firms & 3329 & 3329 & 3329 & 3326 & 3326 & 3326 & 3326 & 3326 & 3326 \\
\hline
\end{tabular}

Note: Marginal effects; Standard errors in parentheses. The independent variables are lagged by two periods. Estimation is done by conditional Poisson fixed-effects regressions (HHG). Firms are classified into five bins by the stock of total patents in 1995 with 25th, 50th, 75th and 95th percentiles as four thresholds. Columns (1)-(3) include firm, indsutry-year (IY) and bin-year (BY) fixed effects, while (4)-(9) include firm, indsutry-year, bin-year and country-year fixed effects. In Columns (7) to (9) the macroeconomic variables are the normalized foreign variables previously defined. Foreign GDP gap is interacted with the foreign weight. Standard errors are clustered at the firm-level. ${ }^{*} p<0.1{ }^{* *} p<0.05 ;{ }^{* * *} p<0.01$ 


\section{A.2 Details on the classification of automation patents}

We derived the exact list of keywords in Table 1 after experimenting extensively with variations around them and looking at the resulting classification of technology categories and the associated patents. Relative to the original list of technologies given in the SMT, we did not include keywords related to information network, as these seem less related to the automation of the production process and the patents containing words such as "local area network" do not appear related to automation. We also did not count all laser patents as they are not all related to automation-but we obtain patents related to automation using laser technologies thanks to our other keywords. Furthermore, the $\mathrm{Y}$ section of the CPC classification is organized differently from the rest and is only designed to provide additional information. As a result, we ignore Y codes throughout.

\section{A.2.1 Statistics on the classification}

Table A.1 gives summary statistics on the prevalence of automation keywords across technology categories in machinery, $p(t)$, as well as the prevalence of the 4 main subgroups of keywords: automat*, robot, numerical control (CNC) and labor. The $95^{\text {th }}$ and $90^{\text {th }}$ percentile for the prevalence of automation keywords for 6-digit codes in machinery define the thresholds used to categorize auto95 and auto90 patents. The distributions are quite similar for the C/IPC 6 digit codes and for pairs of IPC 4 digit codes (see also the histograms below). As expected, the distributions are significantly shifted to the right for combinations of $\mathrm{C} / \mathrm{IPC}$ 4-digit codes with G05 or G06. All prevalence measures are right-skewed particularly for 6-digit codes and 4-digit pairs, and even more for the robot and CNC patents. The automat* keywords are also more common as the prevalence of automat* is significantly higher than for the other keywords. Yet, the difference narrows somewhat in the right tail: the $95^{\text {th }}$ percentile for 6 digit codes is $29.4 \%$ for automat* and $13.7 \%$ and $12.7 \%$ for robot and CNC. In fact, the thresholds (5 and 2) used in the definition of the automat* keywords were chosen so that the distributions of the prevalence measures are somewhat comparable. The right tails of the distribution are similar for the prevalence of the robot and CNC keywords.

Figure A.4.a gives the histograms of the prevalence of automation keywords for machinery technology categories which are pairs of $\mathrm{C} / \mathrm{IPC} 4$-digit codes. The histograms are very similar to those of C/IPC 6 digit codes in Figure 1. Figure A.4.b shows the histograms for all combinations of machinery C/IPC 4-digit codes with G05 or G06. The distribution is considerably shifted to the right, in line with expectations since G05 


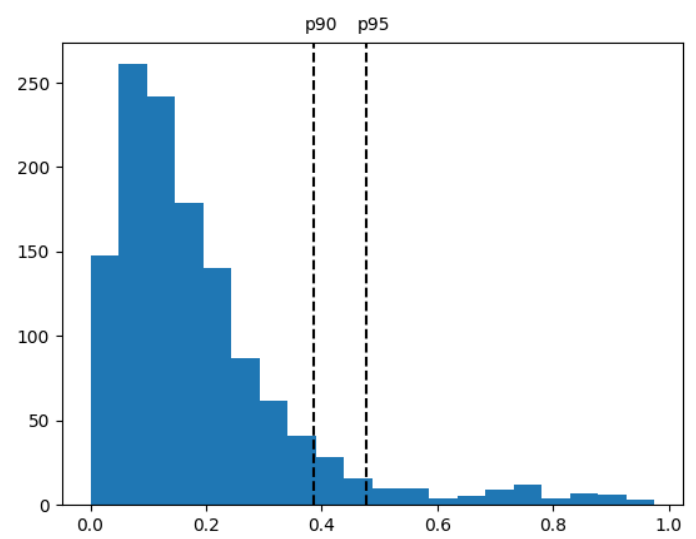

(a) For all pairs of C/IPC 4 digit codes within machinery with 100 patents

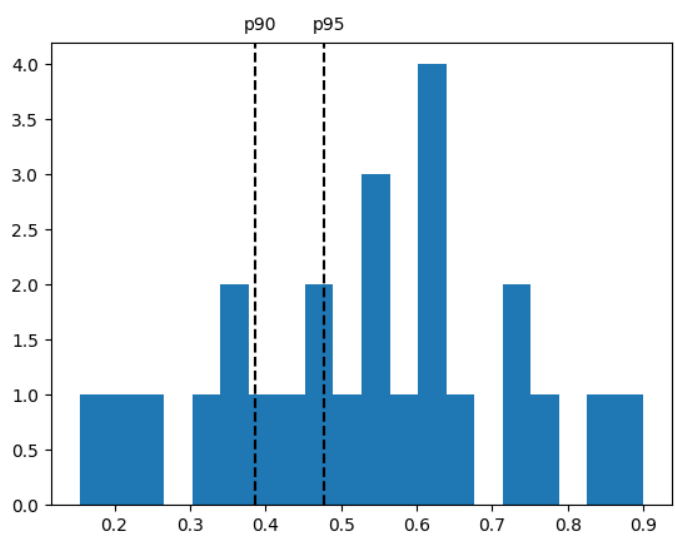

(b) For combinations of IPC4 in machinery with G05 G06 and at least 100 patents

Figure A.4: Histograms of the prevalence of automation keywords. The p90 and p95 lines are those of the 6 digit distribution and mark the thresholds used to define auto90 and auto95 technological categories.

proxies for control and G06 for algorithmic, two set of technologies which have been used heavily in automation. There are, however, many fewer combination of these types, and accordingly fewer patents can be characterized as automation innovations this way.

\section{A.2.2 How are auto90 and auto95 patents identified?}

Given that our classification procedure is relatively complex, we assess here which features dominate. To do so, we focus on the set of 15,212, 134 biadic patent applications in 1997-2011 (corresponding to the 3,187, 536 patent families which have patent applications in at least two countries), since this corresponds to the set on which we run our main regressions. There are 310,458 auto95 patent applications corresponding to 61,768 patent families (and similarly 541,693 auto90 patent applications corresponding to 107,237 patent families). Table A.20.a gives the share of biadic patents which are identified through a C/IPC 6 digit code, a pair of 4-digit codes or a combination of 4-digit code with G05/G06 (the shares sum up to more than 100\% since patents may be identified as automation innovations in several ways). 6-digit codes are the most relevant since they identify close to $80 \%$ of either auto90 or auto95 patents alone.

Similarly, one may wonder which keywords are the most important in identifying automation patents. To assess that, we define robot95 patents as patents which contain a technology category with a prevalence of "robot" keywords above the threshold used to 
Table A.20: Identification of automation technology categories

(a) Type of $\mathrm{C} / \mathrm{IPC}$ codes identifying auto90 and auto95 patents

\begin{tabular}{lcc}
\hline \hline Ipc codes / Patents & Auto90 & Auto95 \\
\hline Matches ipc6 & $78.2 \%$ & $78.7 \%$ \\
Matches ipc4 pair & $17.3 \%$ & $24.3 \%$ \\
Matches ipc4 - G05/G06 combination & $47.7 \%$ & $47.8 \%$ \\
\hline \hline
\end{tabular}

Note: Share of innovations classified as automation innovation through ipc6 codes, ipc4 pairs or ipc4 - G05/G06 pairs. Statistics computed on biadic patents from 1997-2011. (b) Auto patents and subcategories of automation innovations

\begin{tabular}{lccc}
\hline \hline Sources / Patents & Auto80 & Auto90 & Auto95 \\
\hline Auto80 & $100.0 \%$ & $100.0 \%$ & $100.0 \%$ \\
Automat*80 & $36.2 \%$ & $53.1 \%$ & $72.1 \%$ \\
CNC80 & $5.0 \%$ & $8.0 \%$ & $13.2 \%$ \\
Robot80 & $12.0 \%$ & $19.2 \%$ & $33.6 \%$ \\
Auto90 & $62.4 \%$ & $100.0 \%$ & $100.0 \%$ \\
Automat*90 & $21.6 \%$ & $34.6 \%$ & $56.0 \%$ \\
CNC90 & $2.2 \%$ & $3.6 \%$ & $6.3 \%$ \\
Robot90 & $7.8 \%$ & $12.5 \%$ & $21.8 \%$ \\
Auto95 & $35.8 \%$ & $57.3 \%$ & $100.0 \%$ \\
Automat*95 & $4.4 \%$ & $7.1 \%$ & $12.4 \%$ \\
CNC95 & $1.6 \%$ & $2.5 \%$ & $4.4 \%$ \\
Robot95 & $6.3 \%$ & $10.2 \%$ & $17.7 \%$ \\
\hline \hline
\end{tabular}

Note: Share of auto95 (auto90 and auto80, respectively) innovations which are also classified as automat*80/90/95, CNC80/90/95, and robot $80 / 90 / 95$ innovations. Statistics computed on biadic patents from 1997-2011.

define auto95 (namely 0.4766 ), therefore those patents are a subset of the auto95 patents. We define CNC85, automat*95, robot90, CNC90, automat*90, robot80, CNC80 and automat*80 similarly. The other keywords are much less common. Table A.20.b reports the share of auto95, auto90 and auto80 patents which belong to each subcategory. "Automat*" is the most important keyword since $72 \%$ of auto95 patents are also automat*80 patents. "Robot" matters as well with $33.6 \%$ of auto95 patents which are robot80 and $17.7 \%$ which are even robot95 (more than automat*95). CNC does not matter much: only $13 \%$ of auto95 patents are CNC80.

\section{A.2.3 Stability of the classification}

To assess the stability of our classification, we redo exactly the same exercise but instead of using EPO patents from 1978 to 2017, we restrict attention to EPO patents from the first half of the sample (1978-1997), the second half (1998-2017) or the period of our main regression analysis (1997-2011). There is a modest increase in the share of patents with automation keywords within each technology category. At the C/IPC 6-digit level in machinery, the share of patents with an automation keyword increases on average from 0.19 in the first half of the sample to 0.21 in the second half. Nevertheless, the ranking of codes is remarkably stable as shown in Table A.21which reports the correlations of the prevalence measures for the different time periods. 
Table A.21: Correlation between the prevalence of automation keywords for different periods

\begin{tabular}{|c|c|c|c|c|}
\hline & \multicolumn{4}{|c|}{ Prevalence of automation keywords using patents during the period: } \\
\hline & $1978-2017$ & $1997-2011$ & 1978-1997 & 1998-2017 \\
\hline $1978-2017$ & 1 & . & . & . \\
\hline $1997-2011$ & 0.9863 & 1 & . & . \\
\hline 1978-1997 & 0.9693 & 0.9321 & 1 & . \\
\hline 1998-2017 & 0.9885 & 0.992 & 0.9241 & 1 \\
\hline
\end{tabular}

Notes: Correlation matrix for the prevalence of automation keywords by C/IPC 6digit codes in machinery using EPO patents over different time periods. We exclude catch-all categories made at the 4-digit level.

Table A.22: Confusion table for different classification periods

\begin{tabular}{|c|c|c|c|c|c|c|c|c|}
\hline \multirow{2}{*}{\multicolumn{2}{|c|}{ Confusion Matrix }} & \multicolumn{2}{|c|}{$\begin{array}{l}\text { Auto95 based on the } \\
\text { 1998-1997 classification }\end{array}$} & \multicolumn{2}{|c|}{$\begin{array}{l}\text { Auto95 based on the } \\
1998-2017 \text { classification }\end{array}$} & \multicolumn{2}{|c|}{$\begin{array}{c}\text { Auto95 based on the } \\
\text { 1997-2011 classification }\end{array}$} & \multirow{2}{*}{ Total } \\
\hline & & Yes & No & Yes & No & Yes & No & \\
\hline \multirow{3}{*}{$\begin{array}{c}\text { Auto95 based on } \\
\text { the } 1978-2017 \\
\text { classification }\end{array}$} & Yes & 240,194 & 70,264 & 280,047 & 30,411 & 262,972 & 47,486 & 310,458 \\
\hline & No & 53,137 & $14,848,539$ & 25,186 & $14,876,490$ & 26,368 & $14,875,308$ & $14,901,676$ \\
\hline & Total & 293,331 & $14,918,803$ & 305,233 & $14,906,901$ & 289,340 & $14,922,794$ & $15,212,134$ \\
\hline
\end{tabular}

Notes: The statistics are always computed on patents from 1997-2011.

Further, focusing on the same set of biadic patent applications in 1997-2011, Table A.22 shows confusion tables on the classification of patents as auto95 according to each of the classification period. Regardless of the time period used the number of automation patents stays roughly constant. In particular, $85 \%$ of the baseline auto95 patents are still auto95 if we run the classification over the years 1997-2011. This common set of patents then represent $91 \%$ of all biadic patents classified as auto95 patents when using the period 1997-2011 instead of the full sample.

\section{A.3 Comparison with Mann and Puettmann (2020)}

We considered the machinery (according to our definition) of Mann and Puettmann (2020, henceforth MP) and them as auto95 or not (at the family level). We have a lower share of automation patents $(18.5 \%$ for auto90 and $10 \%$ for auto90) than MP who have $30.8 \%$. $70 \%$ of our auto95 patents are classified as automation patents by MP (to analyze this number, it is useful to note that their algorithm has a $17 \%$ false negative error rate on the training set), while we classify $22.7 \%$ of their automation patents as auto95. Therefore, our measure of automation is generally stricter than theirs although it is not a perfect subset.

To facilitate comparison, we computed the share of automation patents at the $\mathrm{C} / \mathrm{IPC}$ 


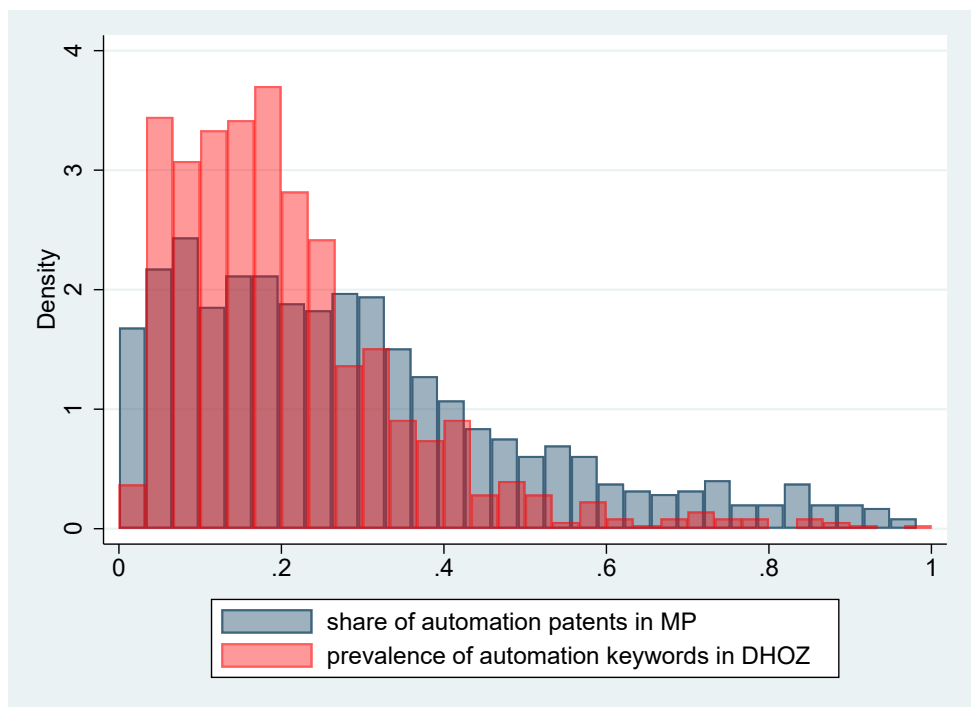

Figure A.5: Histograms of the share of automation patents in MP and of the prevalence of automation keywords in this paper at the 6 digit level in machinery.

60digit level according to their classification and compare this number with our measure of the prevalence of automation keywords. The correlation between these two measures is high (at 0.58). Figure A.5 shows the histograms of the two distributions. Our prevalence measure is more skewed and has a fatter tail (with a kurtosis of 7 versus 3.5), as such it more clearly identifies a set of outliers among 6-digit $\mathrm{C} / \mathrm{IPC}$ codes.

We compute the difference between our prevalence measure and their share of automation patents and look at the codes with the highest and lowest values (focusing on codes with at least 100 patents in both their dataset and our EPO dataset). Table A.23 lists the 6 codes with the largest positive difference (among auto95 codes) and the 6 codes with the largest (in absolute value) negative difference (among non-auto90 codes). 3 of the codes with a high difference belong to the manipulator subclass (B25J), they correspond to joints (B25J17), gripping heads (B25J15) and accessories of manipulators (B25J19). MP classify a large share of these patents as automation but our prevalence number is even higher. In their definition of automation patents, MP specify that they exclude innovations which only refer to parts of a machine. This accounts for some of the patents in these codes that they do not classify as automation. D01H9 corresponds to "arrangements for replacing or removing bobbins, cores, receptacles, or completed packages at paying-out or take-up stations" for textile machines. The share of automation patents in MP is low at 0.38, however their "raw share" (computed before they exclude certain patents) is quite high at 0.71 . The excluded patents are not chemical or phar- 
Table A.23: Outliers 6-digit C/IPC codes in the comparison between our measure and MP's measure

\begin{tabular}{clcc}
\hline \hline C/IPC 6 digit code & \multicolumn{1}{c}{ Simplified description } & $\begin{array}{c}\text { Prevalence of } \\
\text { automation } \\
\text { keywords (DHOZ) }\end{array}$ & $\begin{array}{c}\text { Share of automation } \\
\text { patents (MP) }\end{array}$ \\
& \multicolumn{1}{c}{ Positive outliers (among auto95 codes) } & & 0.84 \\
B25J17 & Manipulators (joints) & 0.62 & 0.38 \\
D01H9 & Textile machines (arrangements for replacing or removing various elements) & 0.48 & 0.25 \\
B65B2210 & Specific aspects of packaging machines & 0.71 & 0.50 \\
B25J15 & Manipulators (gripping heads) & 0.67 & 0.46 \\
B23P23 & Metal working machines (specified combinations n.e.c) & 0.89 & 0.69 \\
B25J19 & Manipulators (accessories) & & \\
\hline & & & 0.19 \\
B66B2201 & Control systems of elevators & 0.19 & 0.97 \\
B66B3 & Elevators (signalling and indicating device applications) & 0.08 & 0.92 \\
B41J23 & Typerwriters / printing machines (power drive) & 0.16 & 0.82 \\
B66B1 & Elevators (control systems) & 0.14 & 0.89 \\
B41J19 & Typerwriters / printing machines (characters and line spacing mechanisms) & 0.84 \\
B41J5 & Typerwriters / printing machines (controlling character selection) & 0.21 & 0.91 \\
\hline \hline
\end{tabular}

Note: This table lists the 6 auto95 codes with the largest positive difference between the prevalence of automation keywords in our data and the share of automation patents according to MP in their data; and the 6 non-auto 90 codes with the largest negative difference between the two measures. We restrict attention to codes with at least 100 patents in both datasets.

maceutical patents (as emphasized in the paper), but belong to the "other" technological field (according to the Hall-Jaffe-Trajtenberg classification). The same situation occurs for B65B2210 (which is about packaging machines) where their raw automation score is actually at 0.63 and the patents excluded by MP are not chemical. B23P23 is a machine tool subclass (specifically "Machines or arrangements of machines for performing specified combinations of different metal-working operations not covered by a single other subclass") which often involves CNC technologies.

The non-auto90 codes where MP find a high share of automation patents but for which we have a comparatively low prevalence measure are easily identifiable. Among the top 6, half are in the subclass B66B which corresponds to elevators and the other half are in the subclass B41J which corresponds to typewriters and printing machines. In fact, the first 34 6-digit $\mathrm{C} / \mathrm{IPC}$ codes belong to either B66B, B41J or the subclass $\mathrm{B} 65 \mathrm{H}$ which is about handling thin or filamentary material and also involves patents associated with printing machines. It is not surprising that our classifications differ for these types of innovation, since they do correspond to processes perform independently of human action (in line with MP's criterion); yet elevators and printers do not (or at least no longer) replace humans in existing tasks. 


\section{A.4 Redoing ALM}

We detail how we build the variables used in Section 2.6 and provide further results.

\section{A.4.1 Data for the ALM exercise}

Except for the automation measures, we take the variables directly from ALM. We refer the reader to that paper for a detailed explanation. The task measures are computed using the 1977 Dictionary of Occupational Titles (DOT) which measure the tasks content of occupations. Occupations are then matched to industries using the Census Integrated Public Micro Samples 1\% extracts for 1960, 1970 and 1980 (IPUMS) and the CPS Merged Outgoing Rotation Group files for 1980, 1990 and 1998 (MORG). The task change measure at the industry level reflects changes in occupations holding the task content of each occupation constant, which ALM refer to as the extensive margin. Since tasks measures do not have a natural scale, ALM concert them into percentile values corresponding to their rank in the 1960 distribution of tasks across sectors, so that the employment-weighted means of all tasks measure across sectors in 1960 is 50. Our analysis starts in 1970 and drops a few sectors but we keep the original ALM measure to facilitate comparison. As in ALM, the dependent variable in Table 3 corresponds to 10 times the annualized change in industry's tasks inputs to favor comparison across periods of different lengths. Computerization $\Delta C_{j}$ is measured as the change per decade in the percentage of industry workers using a computer at their jobs between 1984 and 1997 (estimated from the October Current Population Survey supplements). For all regressions, observations are weighed by the employment share in each sector.

To map patents to sectors we proceed in 4 steps. First, we build a mapping between C/IPC 4 digit codes and the SIC sector that holds the patent (inventing sector). To do that, we use Autor et al. (2020) who match $72 \%$ of domestic USPTO corporate patents to firms in Compustat. This allows us to assign a 4-digit SIC sector to this subset of patents. We match the USPTO patents to our patent family data from PATSTAT, which we use to get the full set of $\mathrm{C} / \mathrm{IPC}$ codes of the family. We then restrict attention to granted patents in machinery applied for in the period 1976-2010. Each patent family for which we have a sector creates a link between its $\mathrm{C} / \mathrm{IPC}$ codes and that sector. We weigh that link inversely to the number of 6 -digit C/IPC codes in the patent. Counting these connections allows us to build a weighted concordance table between 656 4-digit $\mathrm{C} / \mathrm{IPC}$ codes and $397 \mathrm{SIC}$ codes (at different levels of aggregation), where the industries refer to the industry of invention / manufacturing. 
Table A.24: Sectors with the highest and lowest shares of automation patents

\begin{tabular}{|c|c|c|c|c|c|}
\hline ind6090 & Title & Auto95 & ind6090 & Title & Auto95 \\
\hline \multicolumn{3}{|c|}{ Sectors with the highest share of automated patents in machinery } & \multicolumn{3}{|c|}{ Sectors with the lowest share of automated patents in machinery } \\
\hline \multirow[t]{2}{*}{206} & Household appliances; Radio, TV \& communications equipment; & 0.109 & 802 & Misc. entertainment and recreation services & 0.048 \\
\hline & $\begin{array}{l}\text { Electric machinery, equipment \& supplies; Not specified electrical } \\
\text { machinery, equipment \& supplies }\end{array}$ & & 101 & Dairy products & 0.049 \\
\hline 470 & Water supply and irrigation & 0.101 & 102 & Canned and preserved fuits and vegetables & 0.049 \\
\hline 271 & Iron and stell foundaries & 0.098 & 110 & Gain mill products & 0.049 \\
\hline 212 & Misc. plastic products & 0.096 & 111 & Bakery products & 0.049 \\
\hline
\end{tabular}

Second, to obtain the sector of use we rely on the 1997 "investment by using industries" table from the BEA (at the most disaggregated level, 180 commodities for 123 industries) which gives the flows of investment from commodities to industry available at www.bea.gov/industry/capital-flow-data. Beforehand, we assign commodities to industries using the 1997 make table at the detailed level from the BEA (available at www.bea.gov/industry/historical-benchmark-input-output-tables) which gives the commodities produced by each industry. ${ }^{32}$ We dropped commodities associated with the construction sector which are structures. Combining the two BEA tables, we obtain an investment flow table at the industry level. We combine that table with the $\mathrm{C} / \mathrm{IPC}$ to industry of manufacturing table previously derived to get an $\mathrm{C} / \mathrm{IPC}$ to industry of use table mapping 656 4-digit $\mathrm{C} / \mathrm{IPC}$ codes into $966 \mathrm{SIC}$ industries.

Third, we allocate patent families fractionally to their C/IPC 4-digit codes and use the previous table to assign them to an industry of use in the SIC classification (having restricted attention to the $\mathrm{C} / \mathrm{IPC}$ codes which appear in the table). Fourth, we use a concordance table from the US Census Bureau from SIC industries to the Census industries from 1990 (ind90) given by Scopp (2003) and ALM concordance table from ind90 to consistent Census industries (ind6090) in order to allocate patents to their industry of use in ALM's classification.

Finally, for each sector and time period, we compute the sums of automation patents and machinery patents and take the ratio to be our measure of automation intensity. We exclude sectors with less than 50 machinery patents (so that the number of sectors varies across time periods). Table A.24 shows the sectors with the highest and lowest

\footnotetext{
${ }^{32}$ Since our industries are in SIC 1987, we use concordance tables from the IO industries to NAICS 1997 provided by the BEA and then the weighed concordance table between NAICS 1997 and SIC 1987 from David Dorn's website https://www.ddorn.net/data.htm which we complete with a concordance table from the Census available here (www.census.gov/eos/www/naics/concordances/concordances.html). To generate weights in the mapping between IO industries and NAICS 1997 and to disaggregate the NAICS industries from the capital flow table, we use CBP data from 1998 (https://www.census.gov/data/datasets/1998/econ/cbp/1998-cpb.html).
} 
shares of automation patents in machinery.

To compute the share of automation patents in machinery according to the industry of manufacturing / invention, we proceed as above but skip step 3 with the investment flow table. Once patents are assigned to a SIC industry of manufacturing, we use the same concordance tables to assign patents to an ind6090 industry of manufacturing.

Finally, in robustness checks, we also use an alternative mapping from patents to sectors based on Lybbert and Zolas (2014) who provide a concordance table between IPC codes at the 4-digit level and NAICS 1997 6-digit industry codes. The concordance table is probabilistic (so that each code is associated with a sector with a certain probability). The Lybbert and Zolas concordance tables are derived by matching patent texts with industry descriptions, and as such they cannot a priori distinguish between sector of use and industry of manufacturing. We checked, however, that patents associated with "textile and paper machines" for instance are associated with the textile and paper sectors and not with the equipment sector. In addition, it has the advantage of providing a much more direct mapping between $\mathrm{C} / \mathrm{IPC}$ codes and industries. We attribute patents to sectors fractionally in function of their $\mathrm{C} / \mathrm{IPC}$ codes. To assign patents to the consistent Census industry codes used by ALM, we first use a Census concordance table (https://www.census.gov/topics/employment/industryoccupation/guidance/code-lists.html) to go from NAICS 1997 to Census industry codes 1990, and then again use ALM concordance table.

Table A.25: Changes in routine task intensity and different measures of sectoral automation

\begin{tabular}{|c|c|c|c|c|c|c|c|c|c|c|}
\hline \multirow[t]{2}{*}{ Dependent variable } & \multicolumn{5}{|c|}{$\Delta$ Routine cognitive } & \multicolumn{5}{|c|}{$\Delta$ Routine manual } \\
\hline & (1) & (2) & (3) & (4) & (5) & (6) & (7) & (8) & (9) & (10) \\
\hline $\begin{array}{l}\text { Automation share } \\
\text { (using industry) }\end{array}$ & $\begin{array}{c}-146.44^{* \star *} \\
(26.72)\end{array}$ & $\begin{array}{c}-179.22^{\star \star *} \\
(34.33)\end{array}$ & $\begin{array}{c}-154.22^{\star \star \star} \\
(33.70)\end{array}$ & & $\begin{array}{c}-75.32^{\star \star \star} \\
(14.58)\end{array}$ & $\begin{array}{l}-120.22^{\star \star \star} \\
(28.18)\end{array}$ & $\begin{array}{l}-84.40^{* *} \\
(35.03)\end{array}$ & $\begin{array}{l}-58.62^{*} \\
(34.34)\end{array}$ & & $\begin{array}{l}-53.91^{\star \star \star} \\
(15.56)\end{array}$ \\
\hline $\begin{array}{l}\text { Automation share } \\
\text { (manufacturing industry) }\end{array}$ & & & $\begin{array}{c}-25.85^{\star \star \star} \\
(8.29)\end{array}$ & & & & & $\begin{array}{c}-26.65^{\star \star \star} \\
(8.44)\end{array}$ & & \\
\hline $\begin{array}{l}\text { Automation share } \\
\text { (Lybbert and Zolas) }\end{array}$ & & & & $\begin{array}{l}-26.66^{\star \star \star} \\
(4.83)\end{array}$ & & & & & $\begin{array}{c}-17.09^{\star \star \star} \\
(3.90)\end{array}$ & \\
\hline $\begin{array}{l}\Delta \text { Computer use } \\
1984-1997\end{array}$ & $\begin{array}{c}-17.70^{* \star *} \\
(4.74)\end{array}$ & $\begin{array}{c}-19.02^{* * *} \\
(5.93)\end{array}$ & $\begin{array}{c}-19.28^{\star * \star} \\
(5.65)\end{array}$ & $\begin{array}{l}-17.74^{\star *} \\
(6.79)\end{array}$ & $\begin{array}{c}-17.77^{\star * *} \\
(4.81)\end{array}$ & $\begin{array}{c}-19.43^{\star \star \star} \\
(5.00)\end{array}$ & $\begin{array}{c}-28.15^{\star \star \star} \\
(6.05)\end{array}$ & $\begin{array}{c}-28.42^{\star \star *} \\
(5.76)\end{array}$ & $\begin{array}{l}-11.53^{\star *} \\
(5.48)\end{array}$ & $\begin{array}{c}-18.97^{\star \star \star} \\
(5.13)\end{array}$ \\
\hline$R^{2}$ & 0.24 & 0.30 & 0.37 & 0.39 & 0.22 & 0.19 & 0.24 & 0.32 & 0.29 & 0.15 \\
\hline Observations & 124 & 90 & 90 & 69 & 124 & 124 & 90 & 90 & 69 & 124 \\
\hline
\end{tabular}

Standard errors are in parentheses. Each column presents a separate OLS regression of ten times the annual change in industry-level task input between 1980 and 1998 (measured in centiles of the 1960 task distribution) on the share of automation patents in machinery and the annual percentage point change in industry computer use during 1984 - 1997 and a constant. In columns (1) to (5) the dependent variable is the change in routine cognitive tasks and in columns (6) to (10) the change in routine manual tasks. The automation share measures correspond to the share of automation patents in machinery using different mappings between C/IPC codes and industries. "Using industry" allocates patents to their sector of use and "Manufacturing industry" to their sector of manufacturing following the method described in the paper. "Lybbert and Zolas" uses a concordance table from Lybbert and Zolas (2014). Automation patents are auto95 patents for all columns except (5) and (10) which use auto90 patents. Estimates are weighted by mean industry share of total employment in FTEs in 1980 and $1998 .{ }^{*} p<0.1 ;{ }^{* *} p<0.05 ;{ }^{* \star *} p<0.01$ 


\section{A.4.2 Additional results}

Table A.25 looks at alternative ways to map patents to sectors focusing on the consolidated time period 1980-1998. Columns (1) and (6) reproduce the previous results for this time period (and contrary to Figure 4 control for computerization). In Columns (3) and (8), we add the share of automation patents in machinery where we allocate patents to the manufacturing sector (the inventing sector) instead of the using sector (i.e. we skip the capital flow table step when computing our automation variable at the sectoral level). We restrict attention to sectors where there are at least 50 machinery patents with both measures, which reduces the number of sectors. We also find a negative effect and the coefficient on the share of automation patents in the using sector is not too much altered relative to Columns (2) and (7) which carry our initial regression on the same set of sectors. In Columns (4) and (9), we instead map patents to sectors based on a concordance table from Lybbert and Zolas (2014) between 4 digit C/IPC codes and sectors. This method has the advantage of mapping more directly patents to sectors but cannot distinguish between manufacturing and using sectors. We still find that sectors with a high share of automation patents experienced a decline in routine tasks. Finally, Columns (5) and (10) use the share of auto90 patents in machinery to measure automation in the sector of use. The results are similar but with smaller coefficients than in Columns (1) and (6).

\section{A.5 Macroeconomic variables}

Our main source of macroeconomic variables is the World Input Output Database (WIOD) from Timmer et al. (2015) which contains information on hourly wages (low-skill, middleskill and high-skill) for the manufacturing sector and the total economy from 1995 to 2009 for 40 countries. It further contains information on GDP deflators and PPIs both for manufacturing and for the whole economy. They employ the ISCED skill-classification, where category $1+2$ denote low-skill (no high-school diploma in the US) $3+4$ denote middle-skill (high-school but not completed college) and 5+6 denotes high-skill (college and above). Switzerland is not included in the WIOD database and we add data on skilldependent wages, productivity growth and price deflators using data obtained directly from Federal Statistical Office of Switzerland.

We supplement this data with data from UNSTAT on exchange rates and GDP (and add Taiwan from the Taiwanese Statistical office). We calculate the GDP gap as 
the deviations of log GDP from HP-filtered log GDP using a smoothing parameter of 6.25. To compute the offshoring variable we follow Timmer et al. (2014) and compute the share of foreign value added in manufacturing from the WIOD 2013 (except for Switzerland where we use the 2016 release and assign to the years 1995-1999 the same value as in 2000). For the nominal interest rate, we use the yield on 10-year government bonds with data from the OECD for AT AU BE CA CH DE DK ES FI FR GB IE IT JP NL PT SE US and from the IMF for KR GR LU.

The primary data source for the hourly minimum wage data is OECD Statistics. ${ }^{33}$ For the US, we use data from FRED for state minimum wages and calculate the nation-level minimum wage as the weighed average of the state-by-state maximum of state minimum and federal minimum wages, where the weight is the manufacturing employment in a given state. Further, the UK did not have an official minimum wage until 1999. Before 1993, wage councils set minimum wages in various industries (see Dickens, Machin and Manning, 1999). We compute an employment-weighed industry average across manufacturing industries and use the 1993 nominal value for the four years in our sample (1995-1998) with no minimum wage. Finally, Germany did not have a minimum wage during the time period we study. Instead, we follow Dolado et al. (1996) and use the collectively bargained minimum wages in manufacturing which effectively constitute law once they have been implemented. These data come from personal correspondence with Sabine Lenz at the Statistical Agency of Germany.

\section{A.6 Firm-level patent weights}

We give further details on the firm level patent weights. As mentioned in the text, we only count patents in machinery because some of the biggest innovators in automation technologies are large firms which produce a wide array of products with different specialization patterns across industries. Further, we exclude firms which have more than half of their patents in countries for which we do not have wage information.

In Europe, firms can apply both at national patent offices and at the EPO, in which case they still need to pay a fee for each country where they seek protection. We count a

\footnotetext{
${ }^{33}$ Not all countries have government-imposed hourly minimum wages. Spain, for instance, had a monthly minimum wage of 728 euros in 2009. To convert this into hourly wage we note that Spain has 14 "monthly" payments a year. Further, workers have 6 weeks off and the standard work week is 38 hours. Consequently we calculate the hourly minimum wages as monthly minimum wage $\times 14 /$ [(52 -6) $\times 38]$, which in 2009 is 5.83 euros per hour. We perform similar calculations, depending on individual work conditions, for other countries with minimum wages that are not stated per hour: Belgium, Brazil, Israel, Mexico, Netherlands, Poland and Portugal.
} 
patent as being protected in a given European country if it is applied for either directly in the national office or through the EPO. In addition, we take the following steps in order to deal with EP patents. We assign EP patents to countries when they enter into the national phase. A firm's untransferred EP patents are assigned using information on where that firm previously transferred its EP patents. If a firm does not have any already transferred EP patents, we assign the patent based on a firm's direct patenting history in EPO countries. Untransferred EP patents that are still left are assigned to countries based on the EPO-wide distribution of transfers. We also drop a firm if more than half of its patents are EP patents assigned using the EPO-wide distribution.

Finally, as mentioned in the text we only count patents in families with at least one (non self-) citation. Including all patents generally increases the weight of the country with the most patents, in line with the finding that poor quality patents tend to be protected in fewer countries. However, further increasing the threshold from 1 to more citations does not significantly change the distribution of weights.

\section{A.7 Macroeconomic interpretation of the regression coefficients}

To better understand the magnitude of our coefficients and the effect of spillovers and stock variables, we run a simulation where we uniformly and permanently decrease the skill-premium by 10\% between 1995 and 2009 in all countries and use our results to recompute the share of automation innovations in machinery. Importantly, we stress that one must not interpret the result of this simulation as predictive notably because a change in innovation should in turn affect the skill premium. Yet, our analysis could be used to calibrate a model which predicts that the direction of innovation reacts to changes in the skill premium. We focus on a changes in the skill-premium as it is easier to interpret than a change in low-skill wages keeping high-skill wages constant.

Specifically, we simulate the regression results reported in Figure A.6. We regress both auto95 innovations and all machinery innovations except auto95 on the inverse of the skill premium, the GDP gap, stock and spillover variables and firm and industryyear fixed effects. We consider separately the stocks and spillovers of auto95 innovations, machinery except auto95 innovations and all other innovations.

Figure A.6 reports the results averaged over 500 simulations (using the median gives similar results). ${ }^{34}$ We first compute the direct effect of a decrease in the skill premium

\footnotetext{
${ }^{34}$ The figure reports the share of automation patents for the firms in our regression sample. This differs from Figure 3 since the latter reports the share of automation patents for all firms.
} 


\begin{tabular}{lccc}
\hline \hline Dependent variable & Auto95 & Mach. $\backslash$ auto95 \\
\cline { 2 - 2 } & $(1)$ & $(2)$ \\
\hline Low-skill / High-skill wages & $2.38^{* * * *}$ & & 0.25 \\
& $(0.67)$ & & $(0.51)$ \\
GDP gap & $-4.80^{*}$ & & $-2.96^{* *}$ \\
& $(2.64)$ & $(1.36)$ \\
Stock automation & $-0.16^{* * *}$ & $0.14^{* * *}$ \\
& $(0.05)$ & $(0.03)$ \\
Stock mach. $\backslash$ auto95 & $0.35^{* * *}$ & $0.26^{* * *}$ \\
& $(0.06)$ & $(0.03)$ \\
Stock other & $0.35^{* * *}$ & $0.26^{* * *}$ \\
& $(0.06)$ & $(0.04)$ \\
Spillovers automation & $1.04^{* * *}$ & -0.13 \\
& $(0.36)$ & $(0.21)$ \\
Spillovers mach. $\backslash$ auto95 & $1.14^{*}$ & $2.25^{* * *}$ \\
& $(0.60)$ & $(0.38)$ \\
Spillovers other & $-1.68^{* *}$ & $-1.92^{* * *}$ \\
& $(0.73)$ & $(0.49)$ \\
\hline Fixed effects & $\mathrm{F}+\mathrm{IY}$ & $\mathrm{F}+\mathrm{IY}$ \\
\hline Observations & 49174 & 154965 \\
Firms & 3329 & 10367 \\
\hline \hline
\end{tabular}

Note: Marginal effects; Standard errors in parentheses. The independent variables are lagged by two periods. Estimation is done by conditional Poisson fixed effects regressions (HHG). All regressions include firm and yearindustry fixed effects and include dummies for no stocks or no spillovers. Standard errors are clustered at the firmlevel. ${ }^{*} p<0.1 ; * * p<0.05 ; * * * p<0.01$

(a) Supporting regression

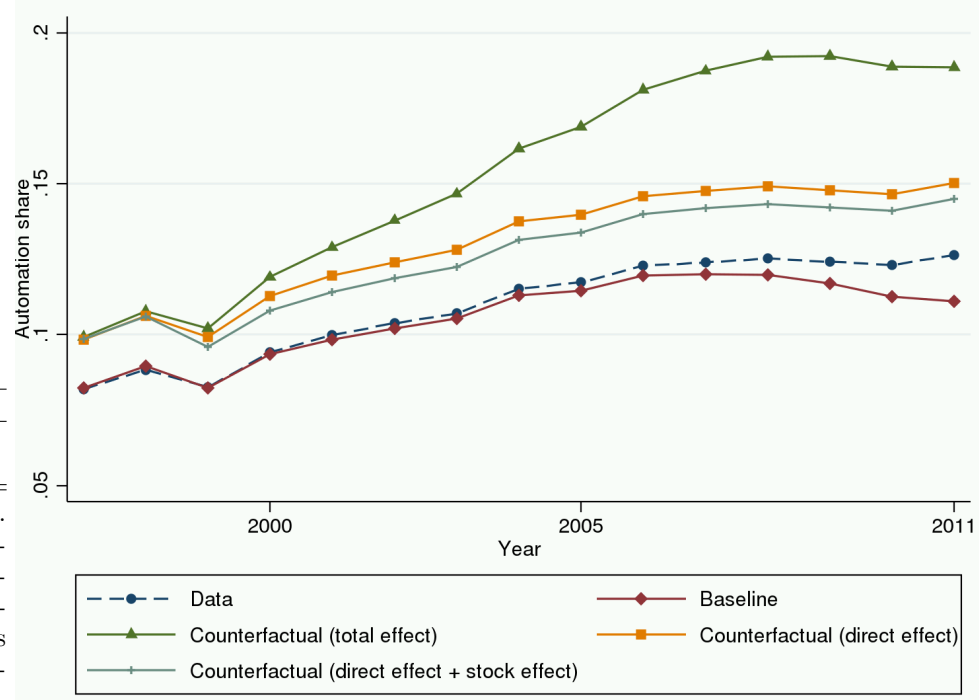

(b) Simulation result

Figure A.6: Simulation of a permanent and global 10\% decrease in the skill premium on the share of automation innovations in machinery

(keeping stocks and spillover variables constant) on the share of automation innovations in machinery. This is captured by the gap between the data curve and the counterfactual (direct effect) curve. This gap reflects the elasticity of 2.38 of auto95 innovations with respect to the inverse skill premium (with an elasticity of 0.25 for other machinery innovations). Taking into account the response of firms' own innovation stocks slightly decreases the effect of low-skill wages reflecting the negative effect of the automation stock on auto95 innovations and its positive effect on other machinery innovations.

We then assess the importance of knowledge spillovers by recomputing the spillover variables for the auto95 innovations and other machinery innovations (but not the nonmachinery innovations). This involves two complications. First, our model only applies to the number of innovations and not their location. To allocate innovations to countries, we assign the simulated innovations proportionally to the firm's inventor weights (used to construct the spillover variables). Second, firms in our sample account for only $58 \%$ of all biadic innovations in 1997-2011. We assume that the other firms respond similarly so that when we assign simulated innovations to countries, we increase innovations by out-of-sample firms to keep the ratio of in-sample to out-of-sample innovations constant. 
The overall effect of an increase in the inverse skill premium is then captured by the gap between the baseline curve and the counterfactual one. The baseline curve and the data series differ because the baseline is an average while the data series is only one possible realization. Knowledge spillovers increase the overall elasticity of the share of automation patents with respect to low-skill wages. The average share of automation innovations in machinery between 1997 and 2011 increases by 4.8 p.p. from $10.5 \%$ to 15.3\%. This is 2.7 p.p. more than the direct effect. This 4.8 p.p. increase can be compared to the 4.4 p.p. increase in the data over the same time period.

To further interpret the 4.8 p.p increase, we use the results of Section 2.6. Using the coefficients from Columns (1) and (6) in Table A.25 (which gives the correlation between tasks changes and the share of automation innovation in 1980-1998), we see that, over a decade, such an increase would be associated with a decline in routine cognitive tasks of 7 centiles and a decline in routine manual tasks of 5.8 centiles. Over this time period, routine cognitive and manual tasks declined at 4.8 and 2.4 centiles per decade. Although one should not interpret these numbers as causal, they indicate that the effect of the skill premium on automation innovations is economically significant.

\section{Online Appendix References}

Dolado, J., Kramarz, F., Machin, S., Manning, A., Margolis, D., and Teulings, C. (1996). The Economic Impact of Minimum Wages in Europe. Economic Policy 11 (23).

Dickens, R., Machin, S., and Manning, A. (1999). The Effects of Minimum Wages on Employment: Theory and Evidence from Britain. Journal of Labor Economics, 17 (1).

Lybbert, T. and Zolas, N. (2014). Getting patents and economic data to speak to each other: An 'Algorithmic Links with Probabilities' approach for joint analyses of patenting and economic activity. Research Policy, 43: 530-542.

Scopp, T. (2003). The relationship between the 1990 Census and Census 2000 Industry and Occupation Classification Systems. US Census Bureau. 


\section{B Supplemental material}

\section{B.1 Additional examples}

We provide a few additional examples of automation and non-automation patents. Figure B.1 shows the example of a robot with a patent containing the IPC code B25J9. The patent describes a multi-axis robot with a plurality of tools which can change the working range of each arm. This essentially increases the flexibility of the robot. Figure B.2 shows an automation innovation used in the dairy industry. The patent contains the code A01J7 which is a high automation code (see Table 2). It describes a system involving a robotic arm to disinfect the teats of cows after milking. The patent argues that this reduces the need for human labor and therefore saves costs. Figure B.3 describes an automated machining device, yet another example of a high automation innovation, which contains the code B23Q15 (a high automation code described in Table 2). The devices features a built-in compensation system to correct for errors thereby reducing the need for a "labor-intensive adjustment process". Figure B.4 describes another high automation patent belonging to the same IPC code as well as to G05B19. This is also a machining device. The patent explains that innovations in machining have aimed at making the process as automated as possible by involving some feedback mechanism (as in the previous older patent). This invention aims at better predicting the machining requirements in the first place.

In contrast Figure B.5 describes a low automation innovation in machinery (none of the codes are above the 90th percentile in the 6 digit $\mathrm{C} / \mathrm{IPC}$ distribution). The innovation relates to a "conveying belt assembly for a printing device", which is about the circulation of paper in the printing machine. This innovation does not directly involve automation. Similarly Figure B.6 describes a winch to raise and lower people, another low-automation innovation in machinery. This innovation seems rather low-skill labor complementary as its goal is to enable workers to move in a plurality of directions. Finally Figure B.7 describes a harvester (which also counts as a machinery innovation since the code A01B63 belongs to other special machinery). This is also a low-automation innovation as its goal is to ensure that the harvester can both operate in the field and travel on roads. 


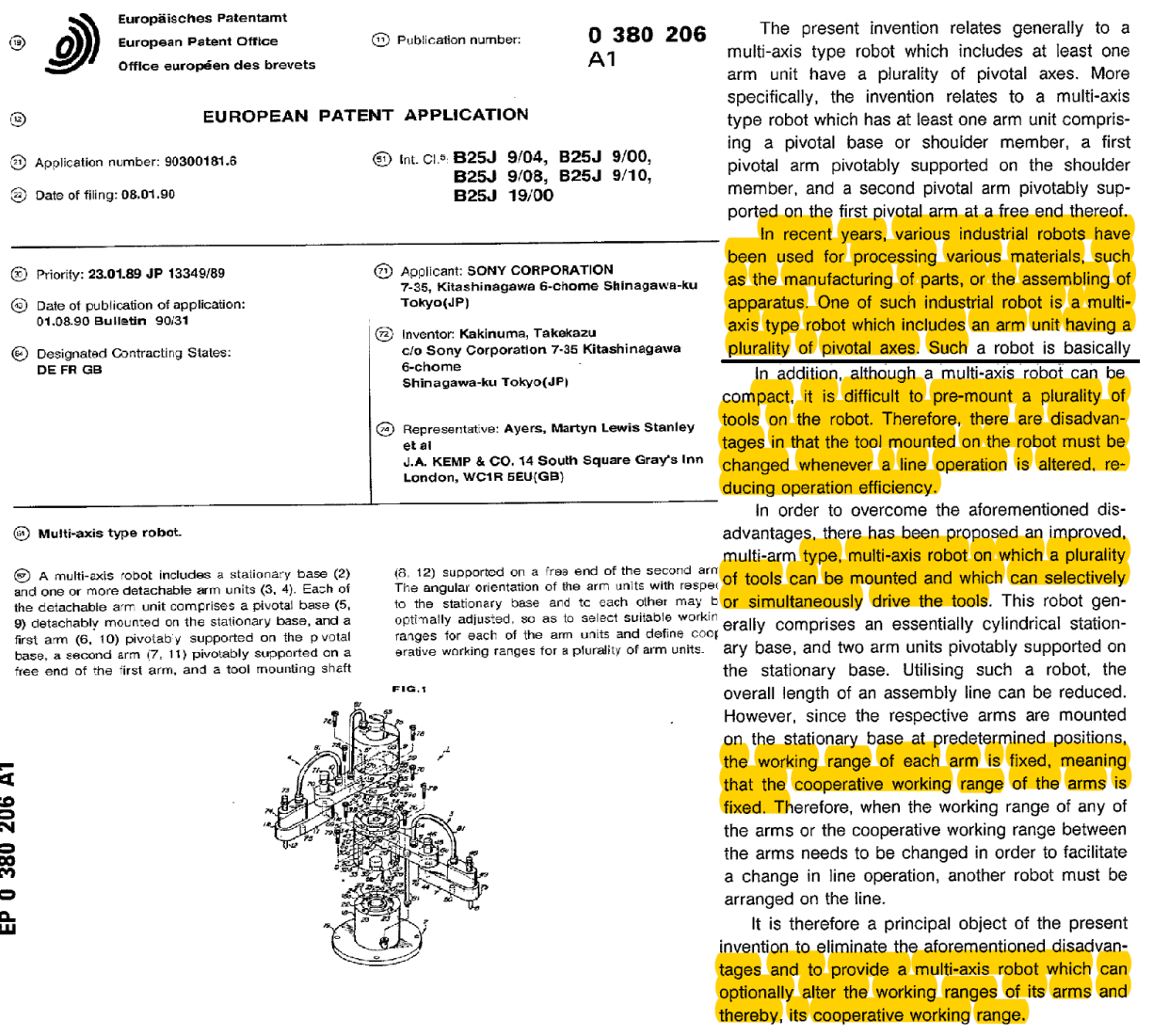

Figure B.1: Example of a high automation patent: an industrial robot 


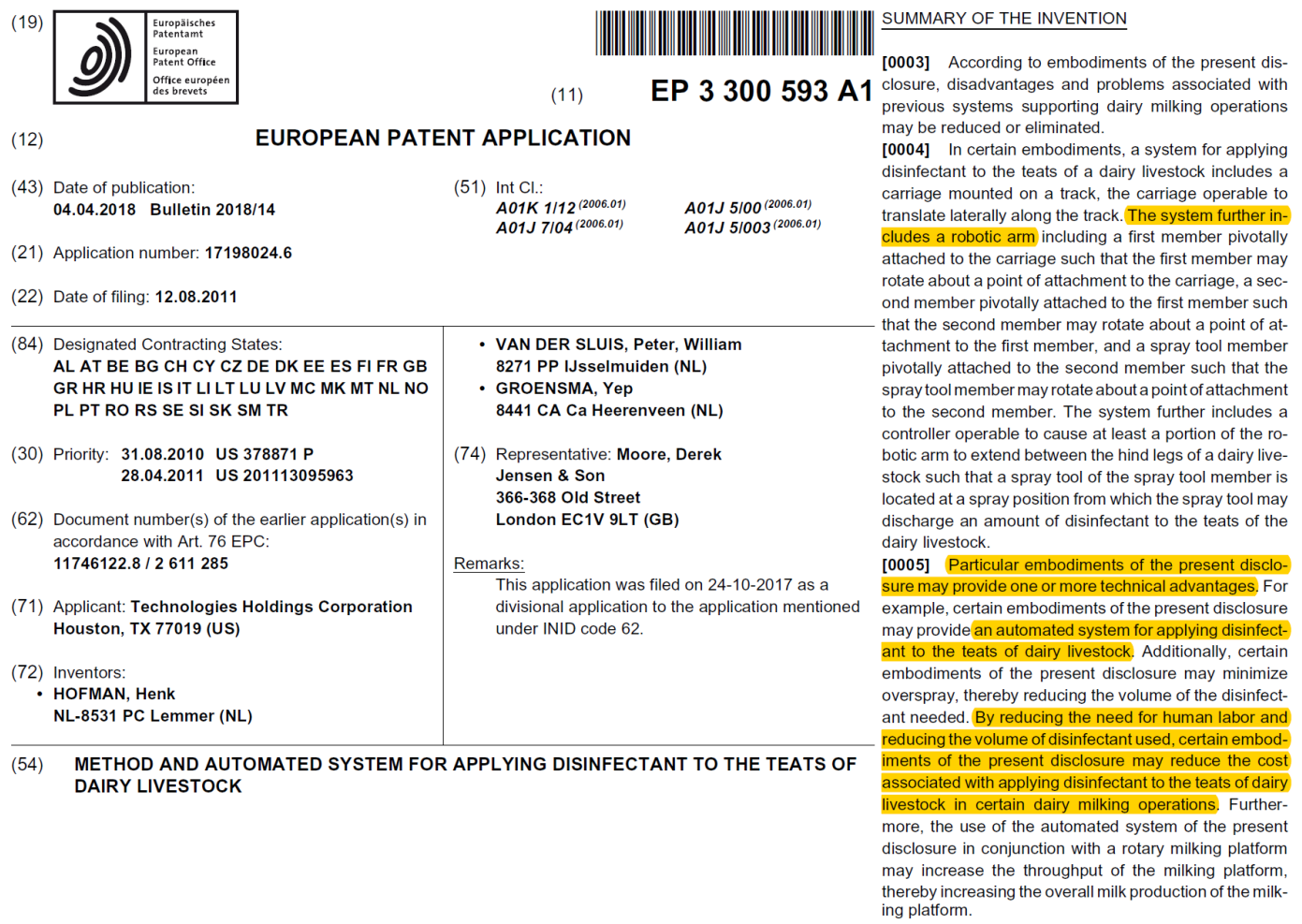

Figure B.2: Example of a high automation patent: a milking robot 


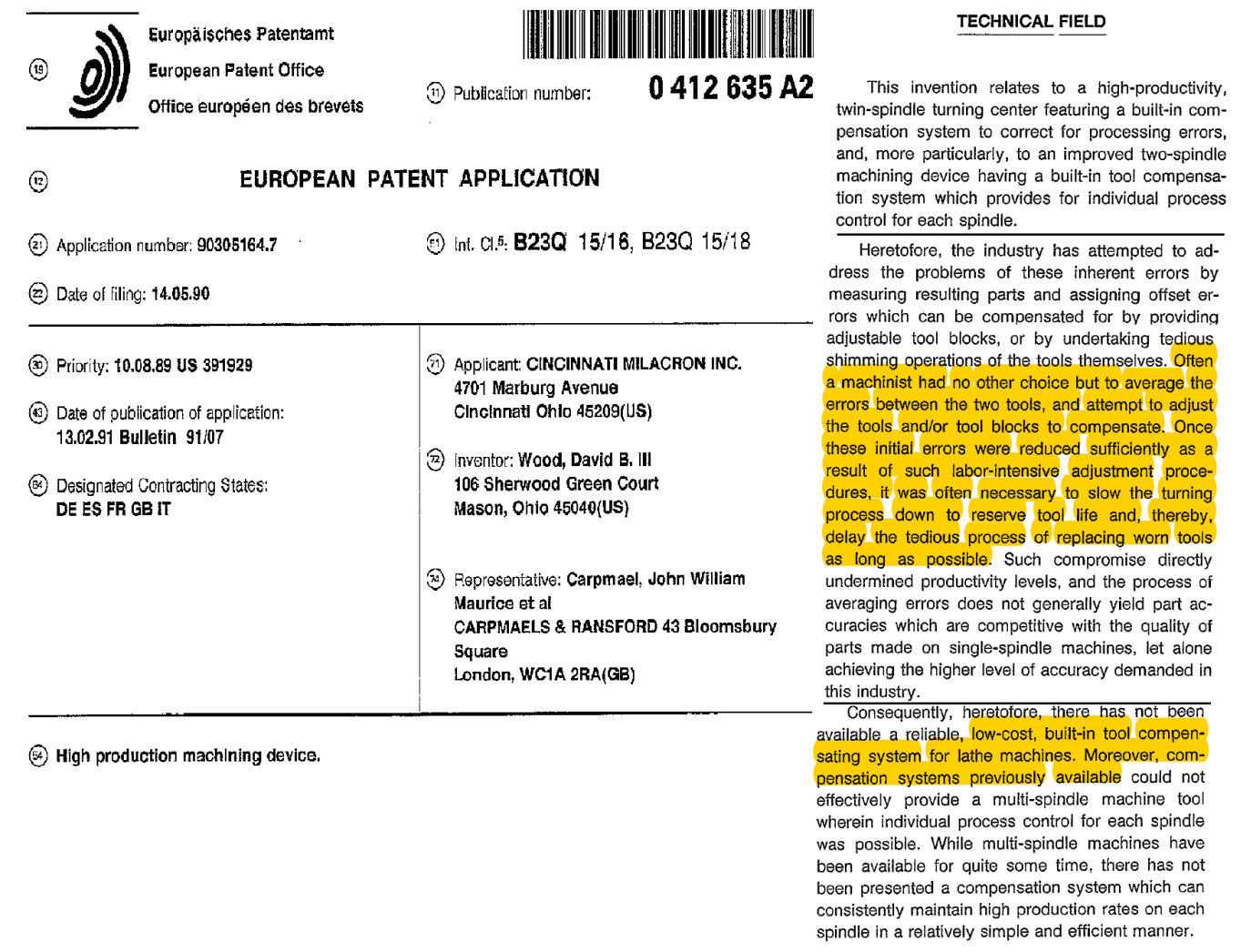

Figure B.3: Example of a high automation patent: an automated machining device 


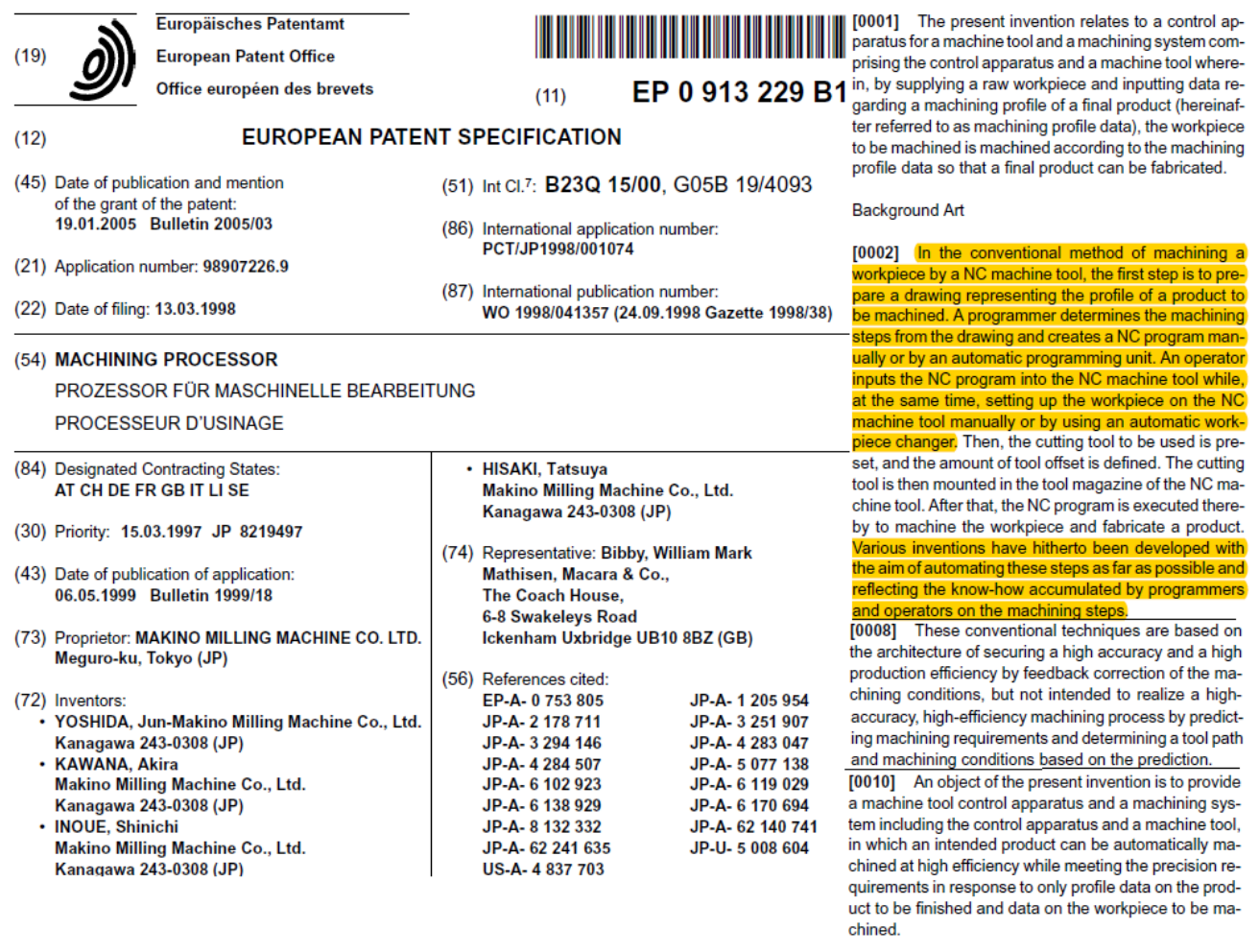

Figure B.4: Example of a high automation patent: another automated machining device

$(19$

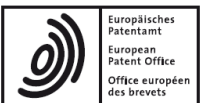

(12)

EUROPEAN PATENT APPLICATION

(43) Date of publication: 02.03.2016 Bulletin 2016/09

(21) Application number: $\mathbf{1 5 1 8 1 7 3 6 . 8}$

(22) Date of filing: 20.08.2015

(84) Designated Contracting States: AL AT BE BG CH CY CZ DE DK EE ES FI FR GB GR HR HUIE IS IT LILT LU LV MC MK MT NL NO PL PT RO RS SE SI SK SM TR Designated Extension States: BA ME Designated Validation States: MA

(30) Priority: 26.08.2014 EP 14182318

(11) P.O. Box 101

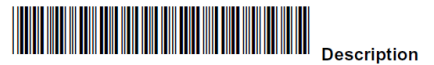

EP 2990363 A1 [0001] The present invention relates to a conveying belt assembly for a printing device, a method for controlling the position of an endless conveyor belt, and the use ling the position of an endless conv.
of a conveying belt assembly. of a conveying belt assembly.
[0002] In printing devices conveying belts are used to transport a sheet of paper through the printing device. The sheet of paper transported through the printing device requires high accuracy in control of its position. [0003] The present invention has as its object to provide a conveying belt assembly for a printing device, which conveying belt assembly allows very accurate control of the position of the conveyor belt or its conveying part. 5914 CA Venlo (NL)

(72) Inventor: ALBERS, Antonius G.H 5914 CA Venlo (NL)

(74) Representative: Cornelissen, Leandra Océ-Technologies B.V. Corporate Patents 5900 MA Venlo (NL)

(54) CONVEYING BELT ASSEMBLY FOR A PRINTING DEVICE

Figure B.5: Example of a low automation patent: a printer 


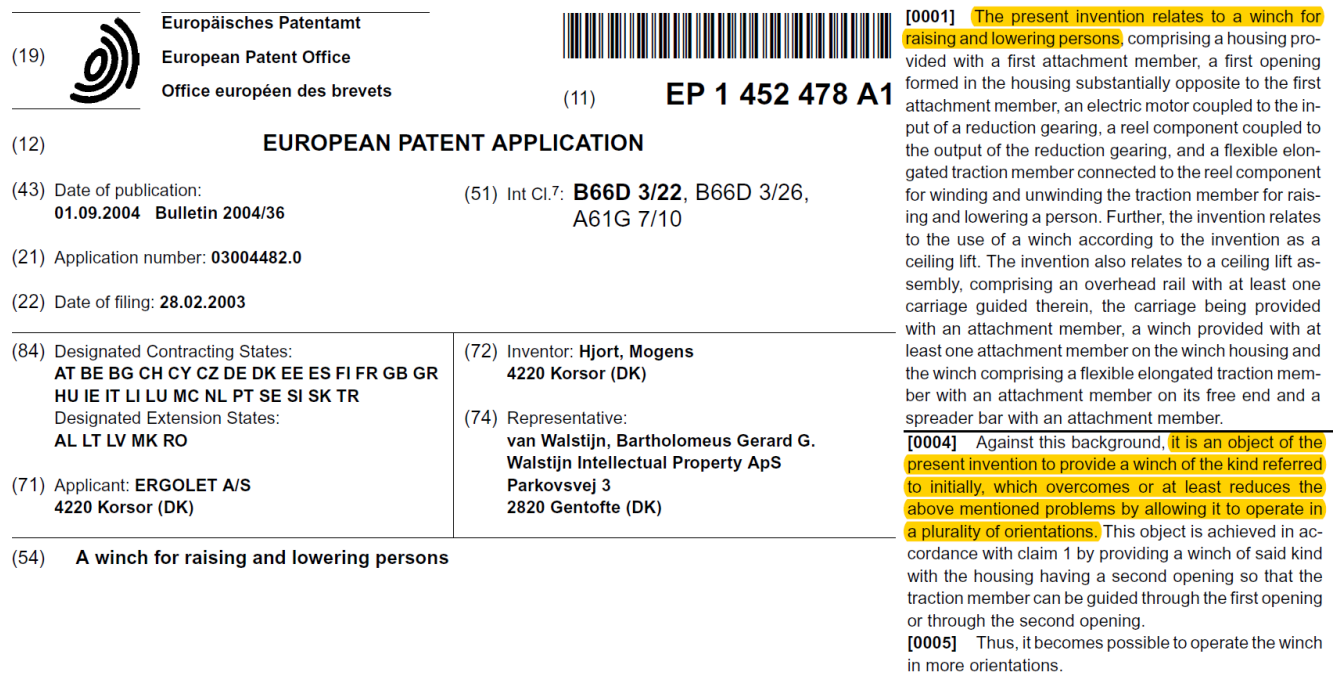

Figure B.6: Example of a low automation patent: a winch

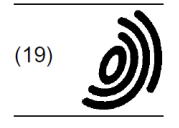

Europäisches Patentamt

European Patent Office

Office européen des brevets

(12)

\section{EUROPEAN PATENT APPLICATION}

(43) Date of publication: 31.07.2002 Bulletin 2002/31

(21) Application number: $\mathbf{0 2 0 7 5 3 8 0 . 2}$

(22) Date of filing: $\mathbf{2 8 . 0 1 . 2 0 0 2}$

(84) Designated Contracting States: AT BE CH CY DE DK ES FI FR GB GR IE IT LI LU MC NL PT SE TR

Designated Extension States:

AL LT LV MK RO S

(30) Priority: 29.01.2001 NL 1017208

(71) Applicant: Frans Vervaet B.V. 4521 PE Biervliet (NL)

(72) Inventors:

- Vervaet, Edwin Joseph Germain

4521 PT Biervliet (NL)

Arnold \& Siedsma,

Sweelinckplein 1
(51) Int Cl.7: A01B 63/00, A01B 73/00

(54) Harvester

4365 NG Meliskerke (NL)

- Vervaet, Robin Richard

4521 PE Biervliet (NL)

(74) Representative: Eveleens Maarse, Pieter

Advocaten en Octrooigemachtigden,

2517 GK Den Haag (NL)

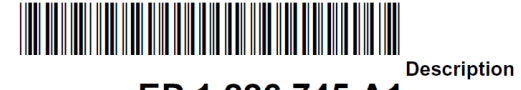

EP 1226745 A1

[0001] The invention relates to an agricultural machine provided with at least one pair of wheels and at least one wheel for performing operations on the land. [0002] Such agricultural machines are generally known.

[0003] In order to perform operations on the land, it is important for stability that the wheels are placed far apart, while for travel without performing operations it is important that the wheels are placed closer together to improve the quality of travel.

0004] The object of the invention is to provide a machine which can meet both requirements.

Figure B.7: Example of a low automation patent: a harvester

\section{B.2 Validating our weights approach}

We compare our firm-level weights to bilateral trade flows and show that they are strongly correlated. The first step is to compute patent-based weights at the country level. For this exercise (and this exercise only), we define the home country $d$ of a firm based on the location of its headquarters (according to the country code of its 


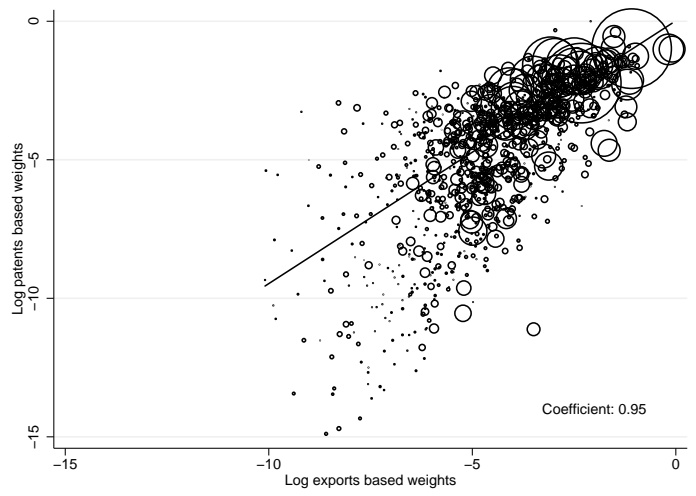

(a) All countries
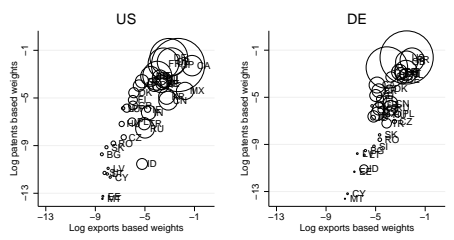

$\mathrm{GB}$
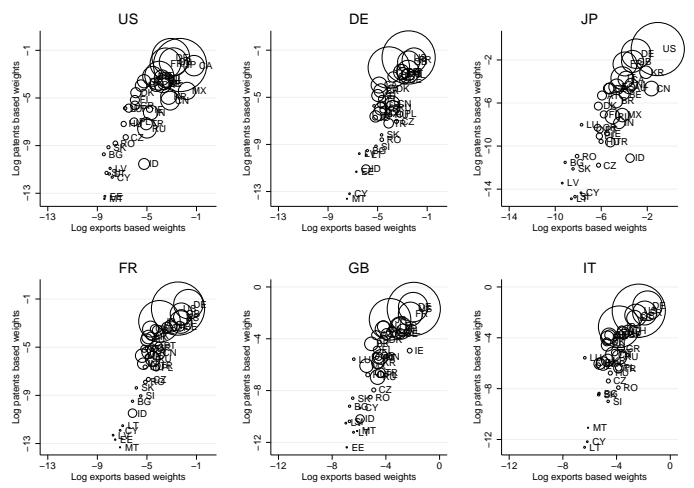

IT

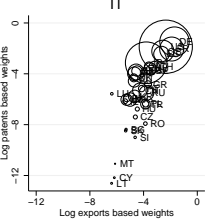

(b) Trade from the 6 largest countries

Figure B.8: Bilateral patent flows and trade flows in machinery. Panel (a) plots log patent based weights, which are a weighted average of the destination country's weights in the (foreign) patent portfolio of firms from the origin country, against export shares in machinery over the years 1995-2009. The size of each circle represents the product of the GDP of both countries, which is used as a weight in the regression. Panel (b) focuses on the weights from the listed countries and observations are weighted by the GDP of the partner country.

identifier in the Orbis database - for firms which we merged, we keep the country code of the largest entity by biadic machinery patents in 1997-2011). We compute the foreign weights for each firm $i$ by excluding the home country. Therefore the foreign weight for country $c \neq d$ for firm $i$ is given by $\omega_{i, c} /\left(1-\omega_{i, d}\right)$ (recall that these weights are computed based on patenting from 1970 to 1994). We then build the foreign patent-based weight in country $c$ for country $d$ as a weighted average of the foreign weights in country $c$ of the firms from country $d$ (each firm is weighted according to the number of machinery biadic patents in 1997-2011).

The second step is to build similar weights based on exports. To do that, we collect sectoral bilateral trade flow from UN Comtrade data between between 1995 and 2009 for 40 countries (Taiwan is not included in the data). To obtain trade flows in machinery, we use the Eurostat concordance table between 4 digit IPC codes and 2 or 3 digits NACE Rev 2 codes (van Looy, Vereyen, and Schmoch, 2014), this concordance table matches IPC codes to the industry of manufacturing. The concordance table assigns a unique industry to each IPC code. Then, for each industry, we compute the share of biadic patents over the period 1995-2009 which are in machinery according to our definition. ${ }^{35}$ This gives us a machinery weight for each industry code and each country.

\footnotetext{
${ }^{35}$ To do that we use a fractional approach: each patent is allocated NACE sectoral weights (and machinery weights) depending on the share of IPC codes associated with a NACE sector or machinery.
} 


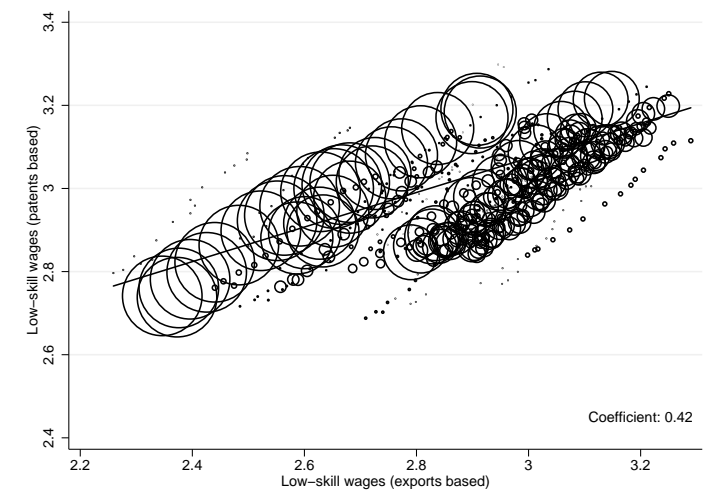

(a) Low-skill wages.

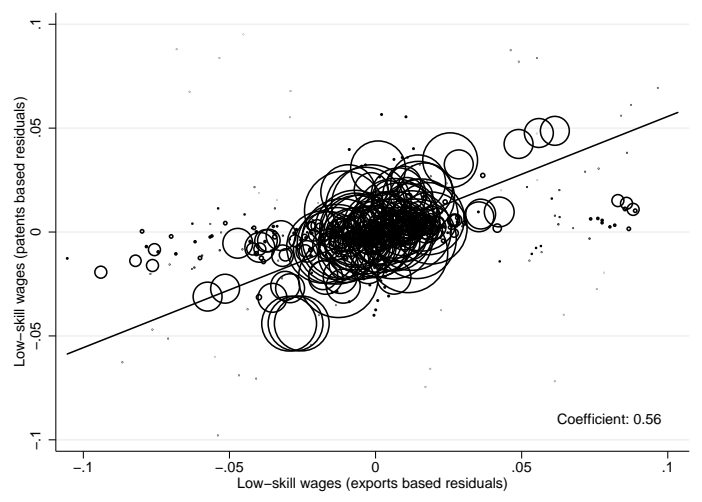

(b) Residualized low-skill wages

Figure B.9: Foreign low-skill wages for each country computed either with patent-based weights or with trade-based weights. Wages are computed for the years 1995-2009. Panel (a) plots log foreign low-skill wages using either patent-based weights or trade-based weights. Panel (b) plots the residuals of foreign wages according to both methods controlling for country and year fixed effects. Observations are weighted by the number of biadic machinery patents by firms from the the country over the years 1997-2011.

We then multiply sectoral trade flows (after having aggregated the original data to the NACE Rev 2 codes used in the concordance table) by this weight to get bilateral trade in machinery. We then compute the export share in machinery across destinations. We compute trade based weights for each year in 1995-2009 and take the average (there are a few missing observations for 1995).

Figure B.8 plots the patent-based weights against the trade-based weights. Panel (b) focuses on a few origin countries while Panel (a) plots all countries together. We find a strong correlation between the two measures with a regression coefficient of 0.94 (when observations are weighted by the trade flow in 1996).

Figure B.9 goes further and compares low-skill wages computed with either sets of weights. For each country, we compute "foreign low-skill wages" as a weighted average of foreign wages where the weights are either the patent-based weights or the trade-based weights derived above. Foreign wages are deflated with the local PPI and converted in USD in 1995 as in our main analysis. Panel (a) then reports foreign log low-skill wages according to both types of weights in 1995-2009 and finds that they are strongly correlated. Panel (b) reports the same foreign log low-skill wages but taking away country and year fixed effects. The regression coefficient is 0.56 , when observations are weighed by the number of machinery patents in the country between 1997 and.

Overall, this exercise shows that there is tight relationship between our patent-based 
weights and (future) trade flows, suggesting that we can use these patent-based weights as proxies for firms' markets exposure.

\section{References}

van Looy, B., Vereyen, C., and Schmoch, U. (2014). Patent Statistics: Concordance IPC V8 - NACE REV.2. Eurostat. 